\title{
The Maryland Power Plant Siting Project: An Application of the ORNL-Land Use Screening Procedure
}

\author{
Jerome E. Dobson
}

\section{MASTER}

Prepared for the U.S. Nuclear Regulatory Commission

Office of Standards Development

Under Interagency Agreement 40-543-75

\section{OAK RIDGE NATIONAL LABORATORY}



Printed in the United States of America Avariabie trom National Technicál Information Service

U.S. Department of Commerce

5285 Port Royal Road. Springfield. Virgınıa $22 i 6 i$

Price. Printed Copy \$5.50: Mir,rofiche $\$ 300$

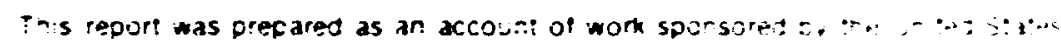

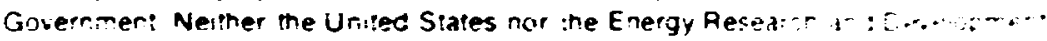

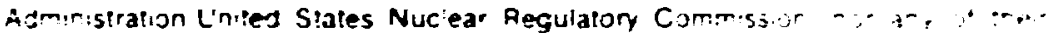

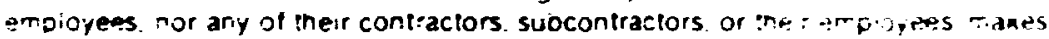

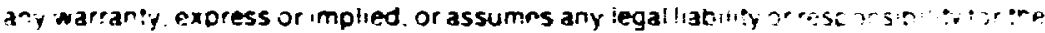
accuracy compleleress or usefulness of any informalon appa:x: . $=\cdots 1, \ldots$

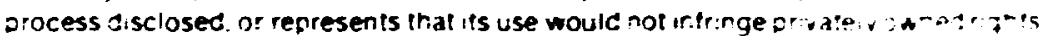


Contract No. W-7405-eng-26

\title{
ENERGY DIVISION
}

THE MARYLAND PONER PLANT SITING PROJECT:

AN APPLICATION OF THE ORNL-LAND USE SCREENING PROCEDURE

\author{
Jerome E. Dobson
}

Manuscript Completed: October 3,1976

Date Dublished: $\therefore$ in: $-i 7$

Prepared for the

U.S. Nuclear Regulatory Comissior. office of Standards Developeent Under Interagency Agreement 40-543-75

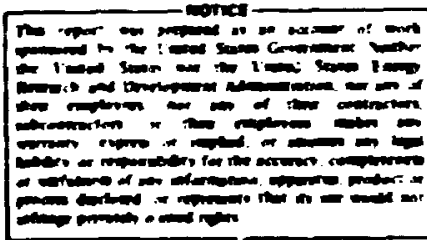

OAK RIDGE NATIONAL LABORATORY

Oaik Ridge, Tennessee $\mathbf{3 7 8 3 0}$

operated by

UNICN CARBIDE CIRPORATION

for tr.e

ENERGY RESEARCH AND DEVEU)PMENT ADAINISTRATION 
MARYind PONER PLANT SITING PROJECT REPORTS

\begin{tabular}{|c|c|c|c|}
\hline Titie & Aurhor (s) & $\begin{array}{l}\text { Document } \\
\text { ORIL/MUREG/nt- }\end{array}$ & Date \\
\hline $\begin{array}{l}\text { The Maryland Power Plant Siting } \\
\text { Project: An Appliwation of } \\
\text { the ORNL Lond Use Screening } \\
\text { Procedroe }\end{array}$ & J. E. Dobson & 79 & i977 \\
\hline $\begin{array}{l}\text { A Cell-Based iand Use Soreening } \\
\text { Procedwe for Regional Siting } \\
\text { Analysis }\end{array}$ & $\begin{array}{l}\text { J. S. Jaliert } \\
\text { J. E. Dobson }\end{array}$ & 80 & 1977 \\
\hline $\begin{array}{l}\text { Power Plant Siting: An } \\
\text { Applioation of the Nominal } \\
\text { Group Process ?echnique }\end{array}$ & A. H. Voelker & 81 & 1977 \\
\hline $\begin{array}{l}\text { A System for Regional Analjsis } \\
\text { of Water Avai Lability }\end{array}$ & $\begin{array}{l}\text { J. S. Jalbert } \\
\text { A. D. Shepherd }\end{array}$ & 82 & 1977 \\
\hline
\end{tabular}




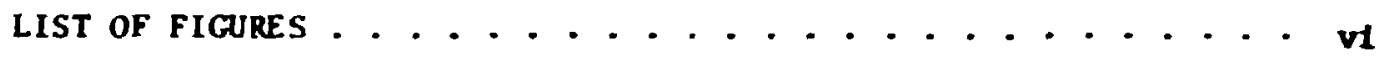

LIST OF TABLES ..................... IX

ABSTRACT ....................... xd

ACKNOHLEDGENTS ..................... xdii

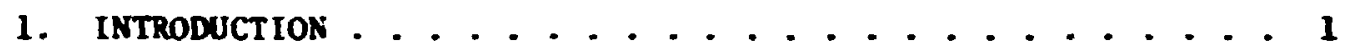

1.1 The Problen of Energy Facility Siting . . . . . . . 1

1.1.1 National scale.............. 3

1.1.2 Regional scale............... 3

1.1 .3 Local scale ...............4 4

1.1.4 Site-spectific analyses.......... 4

1.2 Research objectives.............. s

1.3 Background ................. 6

1.3.1 Maryiand Power Plant Sicing Prograw . . . . 7

1.3.2 Maryland Autonated Geographic Information

Syste. . . . . . . . . . . . . . 7

1.3.3 Western Charles County study ........ 8

1.4 The Study Area ............... 8

2. THE ORNL LAND USE SCREENING PROCEDURE . . . . . . . . . 11

2.1 The Maryland Data Base . . . . . . . . . . . 12

2.1.1 The variables ............. 12

2.2 Ifmulation of Alternatives in the Decision-

aking Process ................ 15

2.2 .1 User or fentation ........... 15

2.2.2 Screening algorithm ........... 15

2.2.3 The problew of averaging ordinal numbers... 17

2.2.4 Interpretation of cell suitability scrres . . 18

3. CRITERIA DEFINITIOR .................... 19

3.1 Miltiobjective Siting Griteria .......... 19

3.2 Methods of Obtaining Criteria Matrices ........ 21

3.2.1 Staff determination of criteria matrices.... 21

3.2.2 Procedures for obtaining a group consensus ... 21

3.3 Ranking of Regional Siting Sactors . . . . . . . . 23

3.3.1 Water avallability'.............. 24

3.3.2 Seisul city . . . . . . . . . . . 26

3.3.3 Presence of rare or endangered spectes ..... 26

3.3.4 Population density and distribution . . . . . 27

3.3.5 Flood hazard ................ 27

3.3.6 Geologic structure . . . . . . . . . . . 27

3.3 .7 Solls ................ . . 28 
3.3.5 Yan-made hazards ............. 29

3.3.9 Water quality ............... 29

3.3.10 other regional screening faccoss........ 30

4. APPLICATION OF THE ORNL LAND USE SCREENINC PROCEDURE

TO NORTHERN MARYLAND . . . . . . . . . . . . . 31

4.1 The Respondents . . . . . . . . . . . . 32

4.2 Comarisons of Criteria Matrices ......... 33

4.2.1 Criteria for a fossil-fired power plant

with a cooling tower: a comparison

=nong siting objectives ......... 33

4.2 .2 Criteria for a nuclear power plant with cooling tower: a comparison anong responcents ............. 36

4.2.3 Cateria for a nuclear or fossil-fired power plant: a comparison between fuel options ................ 38

4.2.4 Crit.ria for a fossil-fired plant with the obje:tive of minimizing afverse ezologic infact: a comparison anong cooling sys te options ............. 40

4.3 The Utility of Multiple Matrices .... . . . . 42

5. ANAlysis OF THE CFLl SUITABIlitY SCORES . . . . . . . 43

5.1 Statistical Analysis ............. 43

5.2 Spatial Analysis ............... 44

5.2.1 Candidace areas for a fossil-fired power

plant: a comparison aeong siting

objectives .............. 45

5.2.2 Candidate areas for a nuclear or fossil-

fired power plant: a comparison between

fuel types................ 50

5.2.3 Candidate areas for a fossil-fired power

plant with the objective of minimizing adverse ecologic impact: a conparison of cooling systen options . . . . . . . . 57

5.2.4 Candidate areas for a nuclear power plant with a composite siting objective: a comparison between respondents ....... 57

5.3 Interpretation of Candidate Area Maps . . . . . . . 64

5.3.1 Candidace areas consistently chozen for a nuclear porer plant ........... 65

5.3.2 Candidate areas consistently chosen for a fossil-fired power plant......... 66

5.3.3 Reliability of candidate-area maps ...... 66 5.3.3.1 Accuracy of the Maryland Data Base ............ 67

5.3.3.2 Missing factors . . . . . . . 68 
5.3.4 Sensitivity of the screening algorithm.... 69

5.3.5 The definition of candidate-areas ..... 73

6. RESEARCH ACCUMPLISHEENTS . . . . . . . . . . . 79

6.I Application and Analysis of the ORNL LUSP . . . . . 79

6.2 Criteria Definition . . . . . . . . . . . . . 79

6.3 Expansion of the Marylana Data Base .......... .

7. CONCLUSIONS, RECOMTENDED APPLICATIONS, AND RESEARCH

NEEDS . . . . . . . . . . . . . . . . . . 82

7.1 Recomended Applications .............83

7.2 Functional Requirenents for Future Applicatirns . - . 84

7.2.1 The geographic inforuation syste. . . . . . 84

7.2.2 The multiscale approach ......... 85

?.3 Suggested Future Research . . . . . . . . . . . 86

ZEFERENCES . . . . . . . . . . . . . . . . 88

Appendix A. COMPATIBILITY INJICES ............ 91

Appendix B. CORREIATION MATPIX OF CELL SUITABiLITY SCORES

OBTAINED FROM CALCULATIONS OF VARIOUS SITING

CRITERIA MUTRICES . . . . . . . . . . . 99 


\section{LIST OF FIGURES}

Figure

Page

1. The northern eight counties of Maryland ......... 9

2. Stylized illustration of potential for an infinite numer of sites within a region ............ 11

3. Candidate areas for a fossil-fire. power plant with cooling tower in northern Maryland, 1976. Siting objective: aniaization of construction and operating costs. Respondent: Maryland Pover Plant Siting Progran. Numer of variables in calculation: 27 .......46

4. Candidate areas for a fossil-fired pow plant with cooling tower in northern Maryland, 1976. Siting objective: ininization of adverse socioecononic ispact. Respondent: Maryland Power Plant Siting Progran. Nunte= of variables in calculation: $27 \ldots 47$

5. Candidate areas for a fossil-fired power plant with cooling tower in northern Maryland, 1976. Siting objective: aninization of adverse ecologic impact. Respondent: Maryland Power Plant Siting Progran. Nuber of varlables in calculation: $27 \ldots 48$

6. Candidate areis for a fossil-fired power plant wit:. cooling tower in northern Maryland, 1976. Siting objective: composite of all objectives. Respindent: Maryland Pover Plant Siting Progran. Muber of variables in calculation: 27 ........... 49

7. Candidace arcas for a nuclear power plant with cooling tower in northern Maryland, 1976. Siting objective: ainini ration of construction and operating costs. Respondent: Maryland Power Plant Siting Progran. Nuber of variables in calculation: $27 \ldots . . . . .51$

8. Candidace areas for a nuclear jower plant with cooling tower in northern Maryland, 1976. Siting objective: dininization of adverse soc. -eccnonic impact. Respondent: Maryland Power Plant Siting Program. Nuber of varlables in calculation: 27 . . . . . 52

9. Candidate areas for a nuclear power plant with cooling tower in northern Maryland, 1976. Siting objective: niotulization of adversc ecologic ispact. Respondent: Marylund Power Plant Siting Progran. Nuber of vartables in calculation: 27 ........... 53 
10. Candidate areas for a nuclear pourer plant with coolinf tower in northern Maryland, 1976. Siting objective: coeposite of all ob. -ciives. Respondent : Maryland Power Plant Siting Progran. Nuber of variables in calculation: 27............... 54

11. Candidate areas for a nuclear power plant with cooling tover in northern Maryland, 1976. Siting objective: nininization of adverse ecologic inpact. Responient: Oak Ridge kational Laboratory. Nutier of variables ¿n calculation: $20 \ldots . . . . . . . . .55$

12. Candidate areas for a fossil-fired power plant with cooling tower in sorthem Maryland, 1976. Siting cbjective: ninteization of adverse ecologic ispact. Respondent: Oak Ridge Mational Laboratory. Nubber of variables in calculation: $20 \ldots . . . . . . .56$

i3. Candidace areas for a fossil-fired power plant with cocling pond in northern Maryland, 1976. Siting obfective: animization of adverse ecologic inpact. Respondent: Oaix Ridge Mational Laboratory. Nuber of variables in calculation: $20 \ldots \ldots$

14. Candidate areas for a fossil-fired power plant with once-through cooling technology in northern Maryland, 1976. Siting objective: aininization of adverse ecologic impact. Respondent: Oak Ridge lational Laboratory. Huber of variables in calculation:

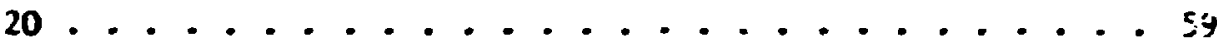

15. Candidate areas for a nuclear power plant wth coolins tower in northera Maryland, 1976. Siting obfective: compsite of all objectives. Respondent: first noninal group. Nuber of variables in calculation: 29 ................ 60

16. Candidate areas for a nuclear power plant with cooling tower in northern Maryland, 1976. Siting objective: compasite of all objectives. Respondent: second noninal group. Nuber of variables in calculation: 29 ............ 61

17. Generalized candidate areas for a nuclear power plant with cooling tower .................. 62

18. Generalized candidate areas for a fossil-fired power plant with coollng tower ................63 
19. Coefficients of correlation between cell suitability scores calculated with all variables and scores calculated with successively fewer variables. The scores are those obtained from the first nominal group's criteria matrix for a nuclear power plant with cocling tower .................. n 11

20. Candidate areas for a nuclear power plant with sooling tower in northern Maryland, 1976. Siting objective: composite of all objectives. Respondent: first noainal group. Nuber of variatles in

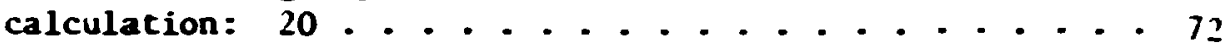

21. Candidate areas for a nuclear power plant with couling iower in iorthern Maryland, 1976. Siting objective: composite of all objectives. Respondent: first nominal group. Number of variables in calculation:

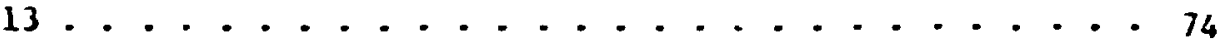

22. Candidate areas for a nuclear pover plant witl cooling cower in northern Maryland, 1976. Siting objective: composite of all objectives. Respondent: finst noninal group. Numer of variables in calculation: 5 .................... 75

23. Candidate areas for a nuclear power plant with cooling tower in northern Maryland, 1976. Siting objective: composite of all objectives. Respondent: first noninal group. Nuber of variables in calculation: 4 .................... 76

24. Caudidate areas for a nuclear power plant with cooling cower in nor thern Maryland, 1976. Siting objective: composite of all objectives. Respondent: Maryland Power Plant Siting Progras. Numer of variables in calculation: 27. Candidate areas are mean score or above .................... . 77

25. Candidate areas for a nuclear power plant with cooling tover in northern Maryland, 1976. Sizing objective: composite of all objectives. Respondent: Maryland Power Plant Siting Program. Numer of variables in calculation: $2 i$. Candidate areas are one standard deviation below mean score or above . . . . 78 
LIST OF TABLES

Table

1. The Marvland Data Base............... 13

3. Criteria matrices determine? in ta : Maryland Power Plant Siting Project by icility, ujlective, and

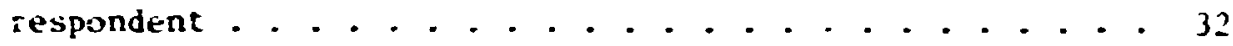

3. Importance weights (on a scale of 0 to 10) assigned tu variables in the Mar:land data base for siting a 100nto 1100-yhe fossil-fired pouer flant witis cooling tower as determined by the Maryland Power Plant Siting Program................ 34

4. Catpogries and values of variabies assigned exclusions for siting a 1000- to 1100-Yáe fossilfired power plant with couling tower as determined by the taryland Poirer Plant Siting Progran for varions objectives . . . . . . . . . . . . . . 35

5. Importance weights (on i scale of 0 t.s IC) assigned by respordents to variables in the Marylanj data base for siting a 1000- to liv0-Mhe nuclear power plant with cooling tower with a composite siting ob jective .................. . . 37

6. Categories and yalues o: variables assigned exclusions by respondents for siting a 1000 - to 1100-Yhe nuclear power plant with cooling tower with $>$ compozile siting ob jective . . . . . . . . 38

7. Iaportance weights (on a scale of 0 to 19) assigned to variables in the Miryland data base for siting a 1000- to 1100-ye power olant with a conposite siting objective as detemined by the Maryland Power Plant Siting Program . . . . . . . . . . . 39

8. Categories and values of variables assigned exclusions for siting a 1000- to 1!0J-Mhe power plant with a coaposite siting objective as determined by the Maryland Power Plant Siting Progras ......... . 4î́

9. Importance weights (on a scale of 0 to IC) assigred to var:ables in the Yaryland data base for sitine 1000- to 1100-Me fossil-fired power plants with various cypes of cooling systems with the objective of miniaizing adverse ecologic impact as determined by ORNL . . . . . . . . . . . . . . . . . . 41 
10. Categories and values of variables assigned exclusions for siting 1000- to 1100-MHe fossi:fired power plants with various types of cooling systems with the objective of ninimizing adverse ecologic impact as determined by ORNL . . . . . . . 42

11. Undocumented or erroneous codes in the Maryland Autonated Geographic Information System . . . . . . 67 


\section{ABSTRACT}

Since 1974 the Resource Analysis Group in the Regional and Urban Studies Section of the Oak Ridge National Labcratary (ORNL) has been engaged in deveioping a procedure -or regional and local siting analysis known as the ORNL Land Use Screening Procedure (1.USP;. This document is the final report of the Maryland Power Plant Siting Project (MPPSP) in which the ORNL LUSP was used to identify candidate areas for power plant sites in northern Maryland.

Numerous candidite areas are identified on the basis of four different siting objectives: the minimization of adverse ecologic impact, the minimization of adverse socioeconomic impact, the minimization of construrion and operating costs, and a composite of all siting objectives. Siting criteria have been defined for each of these objectives through group processing techniques administered to four different groups of siting speciaiists. The siting priorities and opinions of cach group have been expressed quantitatively and applict to a geographic information system cortaining 52 variables for eact. 9 i.8-acre cell in the northern eight counties of Maryland.

Sensitivity analyses reveal that the spatial distribution of candidate cells is influenzed considerably by variations in the criteris defined by different groups even for the same siting objective and type of facility. The distribution is highly sensitive to variations in siting objectives, and somewhat less sensitive to the facility type. 
The research presented in this report builds upon results of the Charles County siting study perforned at ORML in 1974. The project was directed by Steven $L$. Yaffee with research assistance by Curtis A. Miller and programing by Ricinard G. Mashburn and Peter A. Lesslie. Between March 1975 and March 1976, there was a gradual turnover of the project staff, and Yaffee remained as principal investigator until August 1975. No members of the original team remain on the MPPSP staff, but the transfer of resaarch responsibilities was gradual enough to assure that their concepts are retained as integral parts of the current sareening procedure. I wish to express my deepest apprectation to all of the project participants both past and presene. I au especially grateful to Jeffrey $S$. Jalbert, who devoted his year of sablatical leave fron Denison University to this project. I thank hit for his continial consultation and help during the formation of the screening procedure, for developing the Water Analysis System, for witing the thewatic mapping and suitability calculation programs, and for managing the data systems during the most recent phase of the analysis.

The following individuals and organizations were instrumental in the development and implementation of this project, and I an most appreciative for their help.

The Computer Sciences Division of ORML provided many of the programs and services necessary to implement this profect. Peter A. Lesslie managed the data systems in 1974 and 1975 and wrote the proximity program. Barbara Lou Bishop assisted in the computer services necessary in the daily operation of the profect. The graphic display and spatial analysis capabilities of the Oak Ridge Geographic Data Systems Group were essential. Phillip R. Coleman and Robert $G$. Edwards were responsible for the interpolation of population densities and calculation of site population factors, and Conald L. Wilson produced candidate-asea maps for the final report.

The Maryland Power Plant Siting Program provide. criceria matrices and inst-ght into the siting process. Paul Massicott, Hilliam N. Jackson, and Kenneth E. Perkins were most helpful in revlewing our procedure. 
The Maryland Department of State Planning contributed 27 variables from their Maryland Autowated Geographic Information System. John C. Antennuci and John P. Morgan were especially helpful.

Hy colleagues in the Energy Division have provided invaluable support and assistance. Alfred $H$. Voelker participated in numerous discussions that initiated and refined the concepts used in this analysis. He was also responsible for the nominal group exercises. Robert B. Honea reviewed the documents and facilitated the operation of the project administratively. Curtis A. Milier initiated the air diffusion impact analysis and provided siting criteria. Carey S. Rosemarin aided the criteria definition and participated ir conceptual development of the procedure. Garvin J. Morris and Mary C. Ogle converted much of the data to digital form and contributed other technical services. Bonnle $w$. Brumitt typed the successive drafts of the reports and provided secretarial services with comendable patience and restraint.

Darrell C. West of the Environmental Sciences Division was responsible for identifying the habitats of endangered species.

Gary V. Downer, of the University of Tennessee Graduate School of Planning, performed numerous comuter runs necessary in the analysis of candidate areas and facilitated the final production and assembly of the repor's. Alf D. Shepherd of the Geography Department assisted in the application and docimentation of the Water Analysis System.

Dale M. Honeycutt, of the Geography Department of Northern Arizona University, was responsible for checking the accuracy and documentation of all MAGI variables included in the Maryland Data Base.

Carl Cater, of the Allegheny Power Service Corporation, provided a utility's view of water avallability for power plant siting.

We appreciate the erf fort and patience that went into the typing and assembling of this report. For this we thank Bonnie W. Brumitt, of the Energy Division, and members of the Technical Publications Department in the Information Division. 


\section{INTRODUCTION}

Increasing local opposition to thr impacts nf proposed energy facilities and regulatory delays in licenetng have pressed the need for a more ccmprehensive and objective means or selecting candidate sites. Many land use decision-makers and regulatory agencies would welcone a procedure capable of Identifying the trade-offs between alternative sites and considering all vieupoints on any siting issue. It is unlikely that such a procedure will be developed, but significant gains have been wade in recent years.

Since 1974 the Rrsource Analysis Group in the Regional and Uxban Studies Section of the Oak Rifge National Laboratnry (ngar); has icen engaged in developing and applying the ORNL Land Use Screening Procedure (LUSP), which is intended to ald in regional screening for power plant sites and in identifying potential conflicts before they becone eat ters of public concern. This is the final report of the Maryland Power Plant Sting Project (MPPSP), in which the WSP was applied to northern Maryland. The research was sponsored by the Nuclear Regulatory Comission and perforwed in cooperation with the Maryland Power Plant sising Progrin. The State of Maryland was chosen because of its comitment to predesignation of power plant sites and its extensive cell-based geographic information systea.

\subsection{The Problea of Energy Facility Siting}

Hisiorically, energy-facility siting was a ter of local concem because enviromental costs were usually borne by the same population as that benefiting frow the production. Most early energy production facilities were located in or near their main centers of Jeand and utilized local resources. For example, during the 18th century, wost European cit les were surrounded by their wain source of energy - a zone of firewood production.: In the United States, many Edstern cities were established at the fall line, where strean descend from the Pledmont to 
the coastal plain, producing abundant vater power. Sarly coal-fired and hydroelectric generating plants were sall facilities located in or near the cities that used tineir output.

The first substantial shift to regional energy networks resulted from large hydroelectric plants consiructed during the 1930 s and 1940s. The land requirements of these plants were great enough to discourage urban locations, and production capacities were too large to serve a single city. Thereafter, the continued developwent of regional utilities and greater econonic efficiencies of large plants (including coal-fired and later nuclear plants) resulted in regional electric transwission grids wth interregional ties. The wholesale distribution of power between comonities and regions disassnciated environmental costs frov production in the perception of loc 1 populations while the expanded size of plants and scales of operation increased regional impacts.

At first, siting decisions were not greatly affected because public opinion generally favored Industrial expansion, environmental awareness was not particularly acute, and contemporary legislation was not geared to enviromental protection. By the 1960 s, energy-facility siting was a regional rather than a local concern. Site selections, however, continued to be conducted as site-specific analyses throughout wost of the 1960s.

The National Environmental Policy Act of 1969 (NEPA) requires that Impact statements contain assessments of alternatives to each proposed Pederally funded or regulated project [Sect. 102 (2)] and encourages pianners and decision-makers to broaden their focuses from site-specific to regional analyses. Current siting practices usually involve almost an intuitive regional selection of a few candidate sites followed by rigorous analyses of their economic and environmental suitabilities. ${ }^{2}$

The consensus derived from our research experience at ORNL is that energy-facility siting wst be viewed in the context of a spatial hierarchy of physical, social, and isnomic systems. Por national energy planning, site selection slsould proceed from the national to the local scale with emphasis at each stage placed on siting criteria most meaning,ful and crucial for the areal units of observation. The suitability of a particular site is determined only after iterative screenings in a step-down procedure from the broadest to the most sperific scale. 


\subsubsection{Narional scale}

At the national scale, energy-facility siting analysis focuses on matters of general concern such as projecifons of energy deaand and the availability of resources (particularly fuels) and capital. Most of the information for which national aggregate figures are meaningful are either ubiquitous or highly wbile. Aggregate capital, for exanple, is much more meaningful than aggregate coal supply, because of the former's high mobility in contrast to the lower mobility and considerable regional disparity of the latter. For most analytical purposes, it is necessary to consider data for areal units much smaller than the study area itself. For example, one can discuss the aggregate national supply of a comodity, but little can be said about its cost or avallability without exanining regional variations.

\subsubsection{Regional scale}

The second level of screening is the regional scale with boundaries defined according to the purpose of the analysis. The preferred regions often have to je modified because of data avallability or other constraints, but an attempt is made to use political units, utility districts, or hydrologic basins depending upon whether emphasis is on water availability or instirutional-social feasibility. Currently, analysis is being conducted with counties as the basic data cells, because they are the smallest areal units for which large amounts of digital data are zvailable natiomide. Their swall slze in the eastern United States (usually about 300 square miles) provides a spatial resolution suitable for regional screenirig.

Regional siting factors which can be examined through a countylevel analysis include distance to load denand, seisuicity, accessibility to major transfortation and transmission corridors, and proxint ty to major population centers. In general, these regional factors are continuous variables which do not vary greatly over distances of less than 25 miles (e.g., seismic activity) or they are discrete variables with categories covering contiguous areas of county size or larger (e.g. , aquifer recharge zones). 
A goal of the regioual siting analysis is to identify areas that appear to be well situated for energy-facility ievelopent pending the availability of suitable specific sites. The courties or sinilar spatial units ranking highest in the regional screening are selected for more detalled analyses at the local level.

\subsubsection{Local scale}

An extansive geocoded data base generally is required for localscale analyses because of the large volume of data involved in characterizing numerous areal unts equal to or saller than the size of a single site. The appropriate variables are those which fore highly discontinuous data surfaces (1.e., those which vary considerably over sall areas). Land surface slope, for exaple, varies so wch over anute distances that an aggregate figure would be waningless for facillty siting if each areal unit were larger than a single site. The ultinate gosis this scale is to identify candidate siting areas of 25 to 100 square miles fron which specific candidate sites can be selected. A high degree of spatial resolution and great variety of information should give considerable credence to the results of a screening procedure of this type.

\subsubsection{Site-specific analyses}

The final step is the analysis of specific candidate sites which have been identified by the local-scale analysis. Usually this involves a detailed environental investigation for each of four or five candidate sites followed by a thorough impact assessment of the most promising site. Because the nuber of potential sites is small and the exact locatlons are known, it is possible to create a tremendous store of information for each location and to apply extensive models to simulate social, econonic, and ecologic ipacts. The goal is to identify a final site which best serves the political and econonic interests of the region with a dinim of adverse environmental 1epact. In practice, site-specific analyses ar? the investigations not fantlis to siting speciallsts today. 
In the application of the multiscale screening procedure, all factors operating at broader scales wust be considered at each of the wre specific levels. A site-specific analysis, therefore, can contain all of the factors of inportance at the national, regional, and local scales along with additional variables. The Maryland Power Piant Siting Project combines regional and local sitfing factors in a cell-based analysis at the local scale.

\subsection{Research Objectives}

The major purpose of this research is to develop an autoanted procedure for identifying the land use suitability of every land parcel within a candidate siting region. Although the current project involves power plant siting, it is intended that the procedure itself should have general capabilities of application to other land uses or facilities. Moreover, it is intended that suitability for any particular land use can be examined from the standpoint of various independent siting objectives. These requirements suggest that the procedure should operate with easily alterable, user-specified criteria and with geographic data of various resolutions (cell sizes).

An equally important purpose is the definition of multiobjective criteria for power plant siting in a regional context. This further inplies the need for understanding the mans by which regional-siting criteria can be expressed as measurable data representing each geographic unit. Thus, a parallel objective is to determine the specific data items which should be included in a geographic base file for power plant siting.

In tis broadest context, the screening procedure is designed to be used in developing spatial scenarios of future energy production and in identifying critical areas where physical, econonic, and social resources appear to be inadequate for or incompatible with production of profected energy requirements. Current research focuses on developing these general capabilities.

The more lumediate objective of this project 18 to aid the Maryland Power Plant Siting Program in predesignating sices for future power plant development. The state has enacted legislation empowering that of fice 
to select and purchase such sites. The power companies can recomend new sites to the state, but they can only develop those which have been approved by the Public Service Comission upon the recomendation of the Power Plant Siting Progran.

It should be noted that ORNL's function in this process is to develop tools for siting rather than to choose sites. The latter is the responsibility of the Maryland Power Plant Siting Progran. Hence, the: final decision will be made by Maryland as to what criteria are employed in the user-oriented siting procedure developed by oRL. The advantage of using the automated procedure is that all criteria can be stated objectively and applied to every land parcel within the : :ate. Moreover, there will be greater assurance that every alternative site is considered.

Additional purposes are to test the applicability of the Maryland Automated Geographiral Information System (MAGI) to actual siting problems and to determine addicional data needs. Specifically, the geographicc base file is to be evaluated in regard to the format of its data, the categorization of key variables, the completeness of the data set, and the accuracy and spatial resolution of the data.

\subsection{Background}

The National Environmental Polfcy Act of 1969 (NEPA) marks the beginning of most truly regional siting approaches. In the same year, long-standing geographic techniques of regional analysis were popularized with the publication of I an McHarg's Design with Nature. 3 The fervor with which many planners adopted Mcharg's overlay-map technique is evidence of their need for workable regional-screening tools.

By 1971, many planners were using computers to store cellular data and print composite maps in an automated procedure similar to the manual application of overlay maps. 4 A major advantage of automated screening techniques is that they offer the option of assigning varying weights to Indicate the relative importance or each varlable in the data base. Current state-of-the-art research focuses on methods of assigning these weights as expresstons of siting criteria. The MPPSP, which began in 1974, 18 an analysis of siting criteria for fossil-fired and nuclear 
power plants with an emphasis on aciating these criteria to regional land-use suitability screening of automated geographic information systens.

\subsubsection{Maryland Power Plant Siting Program}

An interdepartmental program of the State of Maryland, the Maryland Power Plant Siting Prograz was established in 1971 to deal specifically with power plant siting. It was given broad responsibility in environmental impact assessment and an annual budget currently approximating $\$ 7,000,00 C$ with which to evaluate proposed power plant sites, assess the impact of existing power plants, and identify and purchase prospecifve power plant sites. The enabling legislation provided the funds through a surcharge on electricity gererated within the state.

The Power Plant Siting Program is well suited to a regional screening project like the MPPSP because it is responsible for choosing suitable sites throughout the State of Maryland. Moreover, its primary obligation is an unbiased collection and appraisal of information regarding the costs and benefits (including nonmonetary environmental costs and benefits) of potential sites. It represents the consumer, the utility, and any other interest groups with equal concern, and one of its major functions is to assure that a sufficient number of sites are predesignated for development.

\subsubsection{Maryland Automated Geographic Information System}

Automated regional screening procedures depend upon the avallability of extensive geographic information systems which are time-consuming and expensive to build. It is unlikely that any single application such as power plant siting would justify the expense of developing a dedicated system of this type. The MPPSP was considerably expedited by the existence of the Maryland Automated Geographic Information System (MAGI). 5 This geographic bage file was developed in 1974 by the Maryland Department of State Planning (DSP) with technical assistance from the Environmental Systems Research Institute. It is designed to serve a variety of 
planning needs with a high spatial resolution ( 91.8 acres per cell). The data are not structured specifically for power plant siting.

Data for all cells in the northern eight counties of the state vere transferred to ORRL in 1975.

\subsubsection{Western Charles County study}

The initial application of the ORNL screening procedure was to a study area of approximately 240 square miles in western Charles County, Maryland. 6 It was learned that candidate areas can be identified by applying siting criteria to the geographic information system through a mathematical screening algorithm. It was apparent, however, that certain fmprovenents would be necessary if the results were to be accepted by decision-makers. Prot, lems were identified in regard to the completeness of data coverage and the credibility of the siting criteria enployed. It was concluded that no single set of criteria would be accepted by the diverse groups involved in power plant siting issues. The comparative approach to criteria definition and the extended data base in this project are in response to the recomendations derived frct. the westem Charles County study.

\subsection{The Study Area}

The current research focuses on an eight-county study area in northern Maryland (Pig. 1). The counties Cec1l, Harford, Baltimore, Carro11, Frederick, Washington, Allegany, and Garrett form an east-west transect 195 miles in length varying in width from 5 to 35 miles. This configuration has the advantage of sampling a broad spectrum of physiographic and cultural phenomena. The terraln, for example, varies from coastal plain to rolling Piedmont, to the intermittent escarpments of the Ridge and Valley Province, and the rugged slopes of the Allegheny Mountains. The settlement pattern ranges from the dense megalopolis of the east to the sparse rural clusters and individual farms of the west. Similarly, land use intensity and transportation network density decrease from east to west. Its selection was based primarily on the desire of the Maryland Power Plant Siting Program to predesignate a power plant site in western Maryland. 


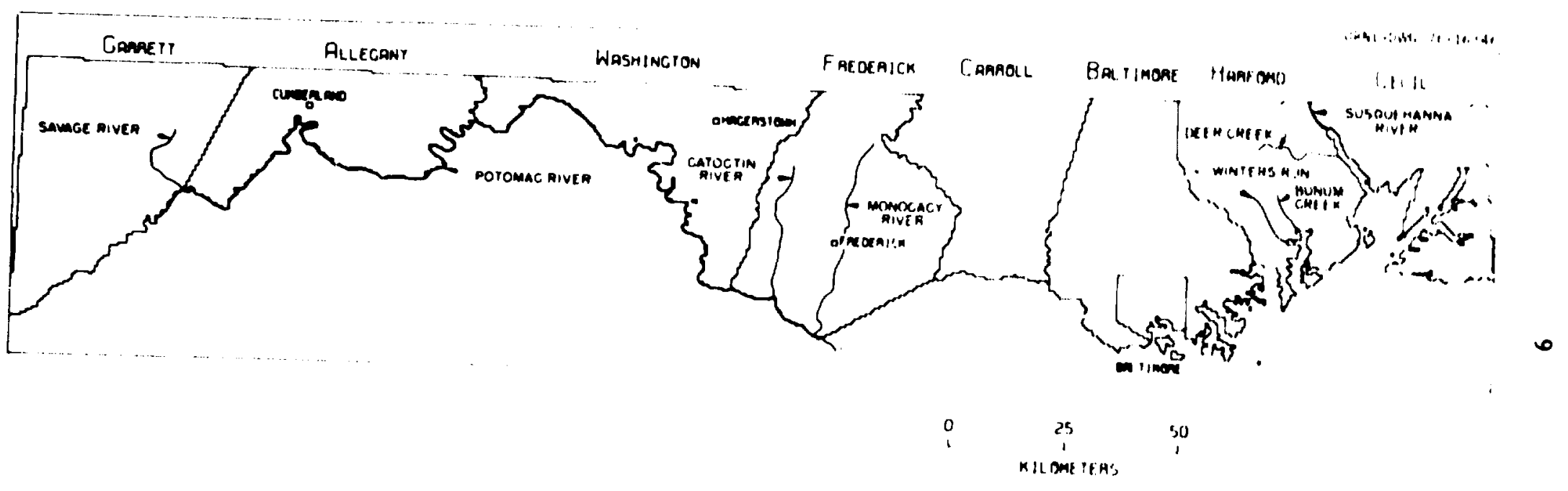

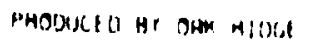

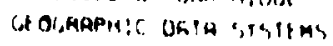

F1g. 1. The nurthern elght countles of Maryland. 
Unfortunately, this sample strip is accompanied by the distinct disadvantage of a long border (aperoximately 430 miles) through areas for which extensive data bases like MAGI are not available. Because of the long, narrow shape, maily cells are adjacent to these areas, and it is impossible to consider adjacent resources and land uses in the evaluation of the cells. This shape, coupled with the high resolution of the data and the large areal extent, has compicated the map presentation of research results The long, narrow form is highly compatiole with line printer output but requizes a disproportionate amount of reduction for most other forms of visual presentation. 
2. THE ORNL LAND USE SCREENIKG PROCEDURE

The requirements of a regional or local screening procedur: are deternined by the large numer of areal units involved. In theory the number of potential sites within a given region is infinite regardless of the region's total area. This can be demonstraied by visualizing the site as a disk of area $A$ with point 0 at its center (Fig. 2). If conplete freedow of movement over the region is persitted, point 0 may become coincident with all of the infinite numer of points on the surface. Each poirc defines a discrete potential site, and the total number of sites is infinite. If the morpho:ogic constraint is dropped and the value of $A$ is allowed to vary, each new configuration may be considered an individual site, and the number of potential sites is infinite even if point 0 remains stationary.

The first step in a regional or local screening analysis is to reduce the potential sites to a finite workable number of discrete areal units. This usially is jone by placing a geometric grid over the area and considering each of the blocks or cells as a potential site. A

ORNL-DWG 76-16368

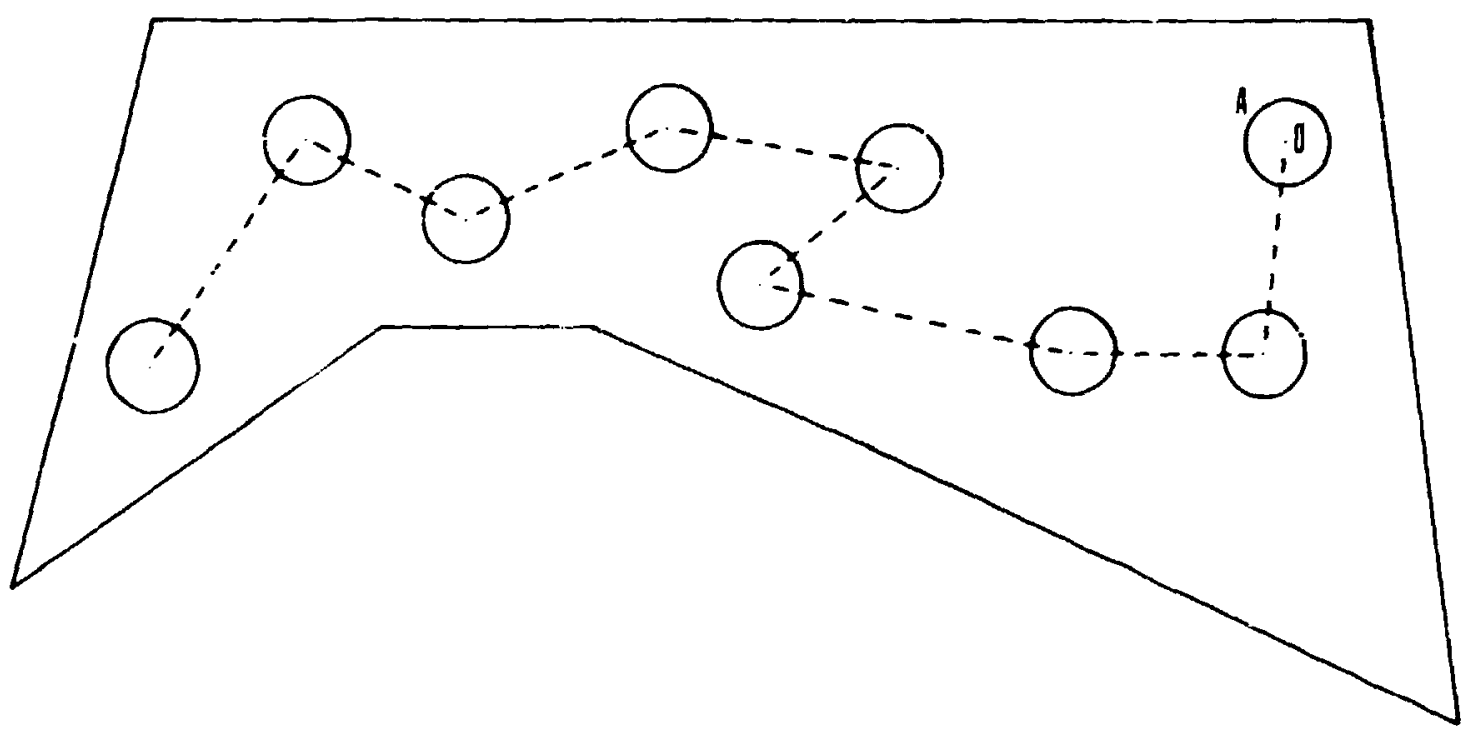

Fig. 2. Stylized 1llustration of potential for ar infinite number of sites within a region. 
hexagonal grid would produce the least distortion in characterizing the data surface, but d rectangular form usually is enployed because of the ease with whicn it can be constructed. Eoth of fer the advantages of regular shape and uniform size for all cells.

It is sometimes necessary to use irregular areal units because of the avallability of data. In regional screening analysis, county units often serve best in the United States because of the extensive data bases available fron the U.S. Census and other Federal sources.

When a regular grid is employed, the size of the cells affects the numer of potential sites under consideration. If the cell size is equal to the area required for a single site, only one potential site is formed by each cell. However, numerous configurations are possible if smaller cells must be combined to form the final site. Cell sizes considerably larger than a single site are inappropriate for analyses in which discrete candidate sites are to be identified.

\subsection{The Maryland Data Base}

The MPPSP itilizes 91.8-acre cells with 52 items of information digitized for each. ${ }^{7}$ The term variable is used throughout this text in referring to the data items. The cells were determined by the Maryland Department of State Planning in the MAGI system and are defined by a rectangular grid with orthogonal intersections at 2000-ft intervals. Each cell is identified by a row number indicating its location or a north-south line and a column number indicating its east-west position. The eight countias of the study area 11 e within rows 1 through 110 and columans 1 througn 530. Haryland State Plane Coordinates for the centroid of each cell can be obtained by the following conversion formulae:

Eastings (in feet) $=[2000 \times($ column number -1$)]+90,000$

Northings $($ in feet $)=700,000-[2000 \times$ (row number -1$)]$

\subsubsection{The variables}

The vartables in the geographic base file (Table 1) are discussed fully in A Cell-Based Land Use Screening Procedure for Regional Siting Analysis. ${ }^{7}$ In summary it can be stated that they cover a broad range of 
Tile 1. The Morylaws Dave Base

\begin{tabular}{|c|c|}
\hline Variable No. & Variatue rame \\
\hline $\mathbf{0 4}$ & Surface water quality \\
\hline 05 & Engreering geology (prinuary) \\
\hline 06 & Enguneering geotogy (secondary) \\
\hline 07 & Transportation and transmission (primary) \\
\hline $\mathbf{0 8}$ & Transportation and transmission (secondar,) \\
\hline 09 & State and Fedtral lands (pxinary) \\
\hline 10 & State and Federal lands (secondary) \\
\hline 11 & Mire al resources \\
\hline 12 & Water and sewer iacilties \\
\hline 13 & Forest rype \\
\hline 21 & Watersheds \\
\hline 22 & Electoral district number \\
\hline 14 & Soil goup (primary) \\
\hline 15 & Soil group (secondary) \\
\hline 16 & Soil goup (tertiary) \\
\hline 17 & Natural features (primary) \\
\hline 18 & Natural features (secondary) \\
\hline 19 & Land :urface slope (primary) \\
\hline 20 & Land sumace siope (secondary) \\
\hline 23 & Historic sites (first in celi) \\
\hline 24 & Historic sires (second in cell) \\
\hline 25 & Historic sires (third in cell) \\
\hline 26 & Land use and land cover (primary) \\
\hline 27 & I.and use and land cover (seccuntary) \\
\hline 28 & Land use and land cover (tertiary) \\
\hline 29 & Planned land ise and land cover (primary) \\
\hline 30 & Pianned land use and land cover (secondary) \\
\hline 31 & Planned land use and land ccur, (tertian of \\
\hline 32 & Highwrys and proposed highways \\
\hline 33 & Seismicity \\
\hline 34 & $\begin{array}{l}\text { Fish spawning and nursing ar eas in } \\
\text { Chesapeake Bay }\end{array}$ \\
\hline 35 & Thirty-mile SPF \\
\hline 36 & Fndariperiod species \\
\hline 37 & Excavation requirements \\
\hline 38 & Overburden thickness \\
\hline 39 & Aquilet recharge rones \\
\hline 40 & Five mile SPF \\
\hline 41 & Stream flow \\
\hline 42 & Population density \\
\hline 43 & Proximity in highways \\
\hline 44 & Proximity to railroans \\
\hline 45 & Proximity ro ster am flow \\
\hline 46 & Proximity to residential land use \\
\hline 47 & Proximity to agricultural land use \\
\hline 48 & Proximity $د$ transmission lines \\
\hline 49 & $\begin{array}{l}\text { Proximit } 10 \text { fish spawning and nursing areas } \\
\text { in Chesapeake } 8 \text { ay }\end{array}$ \\
\hline 50 & Proximity to airports and arrpert property \\
\hline 51 & Proximity to endangered species \\
\hline 52 & Proximity to natural features \\
\hline
\end{tabular}


social, economic, and physical phenomena. Physical characteristics, transportation facilities, and population densities are particularly well represented in the data set becaus: such variables are wre readily available. The structire of the data base is such that each variable is allotted one segmenc of the storage mediu (usually magnetic tape). Within that segment is entered a code indicating the characteristic of that variable occurring within the cell. These characteristics are referred to as "categories" if the variable contains discrete classes and as "values" or "ranges of values" If the variable can assune a continucus spectrun of information. Thus, "scrub oak" is a category within the "forest type" variable, and "30-40 people per square aile" is a range of values within the "population density" variable. Only one code ay be entered for each cell. .

Variables 4 through 41 are referred to as raw variables to distinguish then fron the proxiatty and suitability variables calculated at ORNL. The tern is used sonewhat loosely since several of the "raw" variables have undergone considerable calculation. For example, at ORNL the site population factor (SPF) (a weighted density value of ten enployed by the Nuclear Regulatory Comission in evaluating sites) is derived from U.S. Census Enweration District population totals which are distributed by an interpolation algorithe. The density is then calculated for a circular area of 5 - or 30-aile radius with progressively higher weights assigned to the population within concentric rings nearer to the center. The SPF values then are assigned to cells using another interpolation algorithm. Most of the variables in this set, however, are "raw" in the sense that they have not been manipulated to form factors or indices through combination with other variables.

Varlables 43 through 52 are proxinty calculations indicating the distance between a cell and " nearest cell containing a specified category of a raw variable. Proxinty variables near the border are inaccurate because of a lack of information regarding cells outside the study area. Or.e solution is that all raw variables which are assimed to affect site selection in adjacent cells should be collected for an extended band around the study area. The correction would require additional manpower and could pcse problems of data availabllity and compara- 
bility then jurisdictional boundaries are crossed, but it is aot difficult from a theoretical vieupoint. In the MPPSP the extraneous cells are treated as if they do not exist. No inforation regarding these cells is entered into the calculation of cell sultability scores.

\subsection{Simulation of Alternatives in the Decision-naking Process}

The purpose of a regional siting exercise can be to simulate realworld site selections or to influence and improve the site selection process. In either case it is necessary to consider the values and priorities of the decision-akers and interest groups involved. The approach described in this report is designed to aid the Maryland Power Plant Siting Progran in applying frs orn criteria to the data base and in considering a variety of siting objectives which wight be espoused by different interest groups.

\subsubsection{User orientation}

Most site-screening procedures incorporate the siting priorities and opinions of the specialists who designed thes. In contrast the ORML Land Use Screening Procedure (WUSP) is a user-oriented systew, and the users may incorporate their own opinions and as many different viewpoints as are felt to be necessary. Civergent views can be applied to the data base, and the resulting candidate areas can be displayed cartographically for consideration in the fitlal site selection.

The user ortentation is seen as an advantage because it involves the planner or decision-maker in the development of each calculation and assures that the values under consideration are those of the user. The results thus are wre credible to the user because they are his own. Alternatively he can use the method to simulate the siting patterns thich would result fron employing the values and objectives of other incerest groups. In fact, other interest groups can be asked to subalt theft own criteria to be used in trial runs, and the results can aid in antfcipating their acceptance or refection of sites before final selection.

\subsubsection{Screening algorithe}

The user is presented with a description of the facility to be sited and is asked to consider the importance each varlable would have 
in his siting decision. Each variable in the data base is ranked on an ordinal scale of 0 through 10 ; the rank is referred to as its iaportance veight.

The user is then asked to consider each sategory or value of a variable in regard to the positive or negative influence it would have on his decision if it occurred in a cell. If the category or value is highly compatible with the facility, it is assigned a value of 10 on an ordinal scale of 0 through 10 . An inconpatible characteristic is given a low index on the sane scale, and neutral aspects are assigned a value of 5. These nubers are called compatibility indices. In cases where the variable is of great importance and the category or value is high?! repulsive, a negative compatibility index may be assigned to indicate that cells possessing this characteristic nust be excluded fron the final selection regardless of how attractive their other characteristics my appear. The matrix of importance weights and compatibility indices forms an abstracted, quantitative set of criteria representing the siting priorities and opinions of the user.

The criteria are applied to the geographic data base in a cell-bycell calculation of the form:

$$
s_{i}=\sum_{v=1}^{N} c_{v i} I_{v} / \sum_{v=1}^{N} I_{v},
$$

where

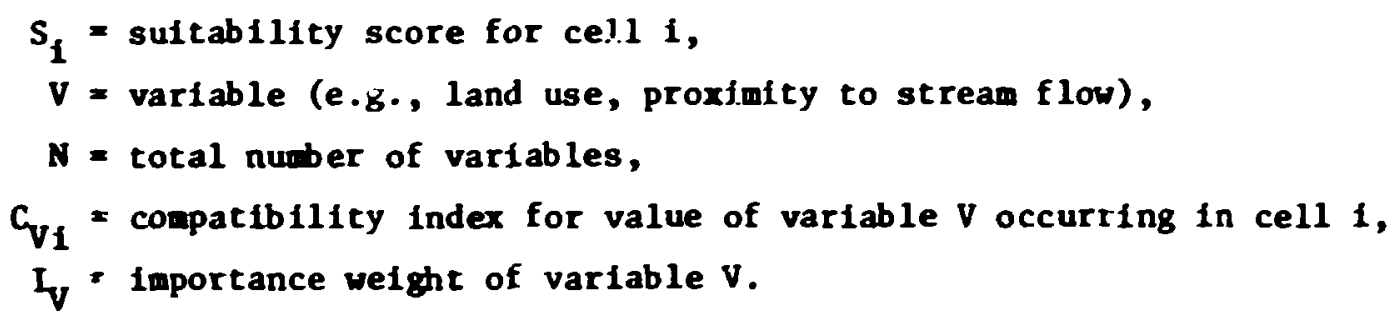

The final suitability score ranging from 1 to 10 is interprete 1 as an indication of the relative ability of a cell to support the proposed facility in accordance with the obfectives of the respondent and subjoct tc the limitatior. of the data. 


\subsubsection{The probles of averaging ordinal nubers}

Quantitative screening algorithes of the type described above are eaployed in several state-of-the-art siting procedures currentiy under development. 8,7 However, there is a theoretical fallacy inherent in the multiplication of importance veights and comatibility indices and in the normalization of indices to obtain a final suitability score. The fundanental problew is that ordinal nubers (nubers indicating order or successton rather than absolute values) way not be linear and, thus, cannot be wltiplied, divided, added, or subtracted. The potential for error derives from the arbitrary manner in which the weights and indices were originally assigned. An importance weight of 6 , for instance, indicates that the variable is wre important than a variable which has been assigned a weight of 3 , but there is no basis for assuning that 6 is twice as important as 3. Neither can it be stated that the difference in importance between 3 and 6 is the same as that between 6 and 9 . Similarly, a compatibility index of 5 indicates greater comatibility than 4, but no indication of the proportional difference is implied. Fur therwore, there is no assurance that the comatibility index range of 0 to 10 represents the same scale on all variables. In other words, it wy be that an index of 10 is twice as compatible as an index of 9 on one variable and 20 tines as comatible on another. The application of inportance weighis is intended to remedy this discrepancy, but, in fact, the ac:ual values represented by the multiple scale cannot be determined from the two sets of ordinals obtained in the usual ranking procedure.

The proble and solutions to the ordinal dilea are discussed fully in Analytical Power Plant Siting Methodologies: A Theoretical Discussion and Survey of Current Practice. 10 For the purpose of this document it will suffice to say that some researchers have treated the indices as ordinal numbers, in which case no conclusion can be reacheo regarding the trade-offs between the combined characteristics of one cell and tnose of another. In contrast, other researchers have devised aethods for assuring that the indices are real numbers which can be entered into quantitative algorithms of the type employed in ORN LUSP. The ChurchmanAckhoff method, for example, iteratively requires respondents to compare between variables and sta: $z$ the proportional value of iaportance weights 
and compatibility indices. Conceptual purity can be attained at a sizable cost in time and inconvenience to the users and respondents. Such an approach is iapractisal tien it is desirable to incorporate numerous sets of criteria from various respondents, particularly if the respondents have no vested interest in the outcome of the screening exercise.

\subsubsection{Interpretation of cell suitability scores}

Regional and local screening analyses require conclusions in regard to trade-offs between cells, and in the MPPSP it was considered desirable to enploy numerous sets of criteria. Hence, it was decidzd that the rankings would have to be treated as real nubers although it would be impractical to assure that they truly were on a uniform interval scale. The inherent potential for error was avided by interpreting only gross differences in final scores as indications of relative suitability, so that the class intervals were significantly larger than the accuulated error. The end result is four classes of cell sultability scores:

1. Exclusion $(-1)$

2. Low suitability (0 to one standard deviation below the mean)

3. Indeterainate scores (one standard devlation belou the mean to one standard deviation above the nean)

4. High sultability (one standard deviation above the mean to 10 ).

Candidate areas are identified as clusters of cells considerably larger than a single site in which all cells score in the highest class. Trade-offs do not pose an acute conceptual problea because no actual comparison is made between the upper and alddle classes or atddle and lower classes. It is reasonable to assume that cells in the high suitabllity class are superior to those in the lou suitability class because the latter have poo: scores on nunerous variables while the former have high scores on all or almost all variables. 


\section{CRITERIA DEFINITION}

The most crucial aspect of the screening procedure is the matrix of importance weights and compatibility indices which deternine the spatial and statistical distributions of the cell suitability scores. If the criteria are obtained in a rigorous and objective maner, they can lend credibility to the candidate area selection. On the other hand, biased or haphazardly concelved sets of criteria can destroy public confidence in the entire procedure. The criteria can be ade highly specific to fit a particular type of factilty characterized by fuel type, cooling technology, and size of plant, or they can be quite general. While this report is linited to power plant siting, there is no reason LUSP cannot be adapted to another land use merely by changing the criteria matrix and perhaps adding variables to the data base.

\section{I Mulliobjective Siting Criteria}

For a utility cuapany there is no alternative but to consider econonic and technical feasibility as primary siting objectives. However, there is no justification for excluding other siting objectives froa consideration, particularly since these, too, may be expressed in terms of monetary costs of delays or of aitigation requirements.

It can be argued that consideration of vartous siting objectives has become a necessary part of power plant siting. Most utilities now perceive an advantage in anticipating environmental impacts before final site selection. For some this represents a pragmatic desire to avoid the delays that can result from hearings, litigations, and detailed inpact investigations. For others ti represents a genuine concern for the environment and heightened awareness of detrimental impacts. In efther case, it is important that the decision-maker be able to cast aside his ow biases and apply the criterla of other interest groups even if he is philosophically opposed to their views. Horeover, the interests of other groups are best served if their opinions are considered before the utility has comitted large sums of mey to a specific site. 
A mathematical algorithe of the type used in LUSP cannot be highly sensitive to individual factors with low importance weights. Hence, it is possible for a ninor siting objective to have little effect on the final cell score even though it may have a profound effect on the site's acceptance or rejection by a particular interest group. In order to ascertain that all appropriate siting objectives have been given full consideration, it is suggested that a separate run be devoted to each. The user or other respondent is asked to create a criteria atrix in which the chosen objective is held paramunt and all others are ignored. Ultimately the scores obtained froveach should be compared with those resulting from the composite matrix. Additional refinement of individual objectives can be attained by choosing at least one respondent with specific expertise in the area of consideration (e.g., a group of ecologists, biologists, and physical geor.zaphers might be asked to create a set of siting criteria focusing on the minimization of adverse ecologic impact).

In the MPPSP, siting criteria were obtained for the following siting objectives (no rarixing of importance is implied):

1. the aininization of adverse ecologic inpact,

5. the niniaization of adverse socioeconomic ispact,

c. the minimization of construction and operating costs,

d. a composite of all siting objectives in the perspective of the respondent.

If properly constructed, these four sets of criteria can cover wost of the issues which have caused general concern anong the utilizies and other interest groups in resent siting decisions. This list of objectives could be subdivided even further. For example, aesthetic inpact or detrimental effects on aquatic blota could be chosen for special emasis within the ecologic objective, and separate criteria eatrices could be constructed. The general cost objective could be replaced by more specific ones dealing individually with land acquisition costs, land preparation costs, and the continuing costs of hazard abatement. The initial. list is not exhaustive. It wold be helpful, for instance, to create a fifth atrix dealing with the maxinization of energy efficiency. 
It is advisable to provide at least one cross-check for the scores obtained for each siting objective. The anticipated application is for the user to define a criteria matrix for each siting objective and to ask groups of topical specialisis to focus on criteria for each according to their fields of expertise. The resulting scores then can be coapared in regard to their statistical and spatial distributions.

\subsection{Methods of Obtaining Criteria Matrices}

In LUSP the user supplies his wn criteria; ORRL cannot control the quality. It is suggested, however, that the user should nake every effort to assure that each matrix is deternined as rigorously as possible and validly represents the criteria of the user or respondent. This section discusses various methods of obtaining the criteria and exphasizes the Noninal Group Process (KG1) as a means of assessing exrert opinion.

\subsubsection{Staff deternination of criteria natrices}

In current siting practice, regional screening is performed solely with the criteria defined by the decision-maker. His perceptions of the constraints which will be placed by regulatory agencies and intervening iroups are incorporated, but the operational criteria clearly are his

own. Even the wost enlightened organization could not be expected ro substitute the criteria of another group, however well respected, for its own. Thus, it is anticipated that the responstble utility conpany or regulatory authority will always wh to have its siting specialists prepare a criteria matrix as the Maryland Power Plant Siting Progras has done in this study.

\subsubsection{Procedures for obtaining a group consensus}

Whether the user organization is forwulating a criteria eatrix from numerous siting specialists within the organization or is attempting to assess the opinions of other interest groups or topical specialists, it is often necessary to condense the opinions of several participants into a single matrix representing the group consensus. It is extremely 
impirtant that this should be done as rigorously as possible because of the important role that the matrix plays in the screening procedure.

Three methods of assessing the judgmental consensus of a group were considered in this study. The Delphi Method is a well-established approach in which questionnaires are adninistered to a selected group of individuals, herein called respondents, in a series of iterative rounds." After each round, the results are sumarized and presented as feedback for the next. The process continues untii the researcher is satisfied that the results validly represent the group consensus. The NGP is one of several task group approaches which require the participants to convene in a panel discussion under highly structured conditions. ${ }^{12}$ The third method, gaming, is an even wore highly structured process, in which each participant plays an assigned role in a well-defined decision-aking situation. Certain rules and assumptions are dictated in an attempt to simulate real-world policies and constraints, and the gane is carried out just as a child's gave is played. The judgents derived from the interplay are assumed to represent the group consensus or a policy compronise which might be obtained in a real-world situation. ${ }^{13}$

A comparison of the three methods reveals differences in the degree of interaction between participants. In the Delphi Method, participants are not required to face each other; their only intercourse is through witten correspondenze at the beginning of each round with intervals of several weeks or wnths. Hence, true interaction is minimal. In contrast, NGP participants are forced to think and speak as a group, and full interaction between group wemers is encouraged. Ganing is perhaps even more interactive because the game design requires that players ust argue among thenselves over every contestable issue, with the judgmental outcome deriving directly from these confrontations.

Considerable disparity in the amount of time required to ohtafn useful results is apparent also. Each of the methods requires fron one to two months to select the participants and obtain their cooperation in the exercise. Preparation for both Delphi and NGP involves careful foraulation of specific questions and is:ues to pi: before the participants. Generally this can be porfared simultanecisly ath the selection of 
participants and does not greatly affect overall tine reyuirements. The construction of a game, however, is an expensive activity which requires several months of development and usually is not perfected for several yoars. 14

After initial preparation, both the NGP and ganing proceed rapidly once the participants have convened, and results can be obtained in a mater of days. In contrast, the Delphi Method ertails several months of intermittent correspondence, with the toral span dependent upon the number of iterations required.

Experience at ORNL has shown that participant attrition poses a serious problem in application of the Delini Method. Presunably the protracted nature of the process causes participants to reconsider their comitments of time and effort. Furthermore, many respondents are intimidated by the complexity and bulk of the survey materials. ${ }^{15}$ Reaction to the NGP has been just the opposite; past participants have been highly enthusiastic and have felt that they learned enough from the experience to justify their expenditure of time. Often the participants value ti: 2 insights exchanged in interactive group discussions as much as the user values the weightings obtained frow the process. These exchanges of insights are totally lacking from the Delphi process, so there is little to compensate a busy executive or other siting specialist for his tine.

The IGP seens best sufted to the needs of regional screening. The time requirement, including preparation and execution, is considerably less than that of the Delphi Method or ganing. This is a significant factor due to the numerous runs involved in LUSP and the need for expedition in wost real-world siting analyses. Moreover, the participants, except those employed by the user organization, usually have no vested interest in the results. The process must use their time efficiently and ake then feel that the imposition is recompensed.

\subsection{Ranking of Regional Siting Fictors}

The application and results of two NGP exercises are described in

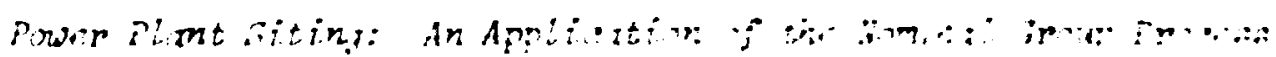


Tesinique, by A. H. Voelker. Siting specialists from OKNL, the Tennessee Valley Authority (IVA), Maryland Power Plant Siting Program, Allegheny Power Service Corporation (the utility providing electric service to west:-in Maryland), and the University of Illinois were asked to nawe, define, ard rank the siting factors which would influence their decisions ir. designating candidate areas for a 1000- to 1100-MWe nuclear power plant with cooling tower. The rankings obtained from each group were used as importance weights in two separate applications of LUSP which will serve as examples in the rewaining clapters of this report. The purpose of this section is to introduce the siting factors as an aid to understanding the criteria matrices to be encountered in Chap. 4. They will be discussed in approximately descending order of importance for a composite siting objective. There is, of course, variation among the different matrices.

\subsubsection{Water avallability}

The avallability of sufficient quantities of water within a reascnable distance of the plant lies at or near the top of the priority list of factors ranked by all respondents, including those determined by the Maryland Power Plar Siting Program. In this context, availability is defined in terms of low-flow characteristics of the stream from which water is tc be withdram. The ability to obtain the legal right to use a portion of a stream's flow is viewed separately by the respondents and generally ranks much lower as an importance factor. Groundwater sources, oceans, bays, and the Great lakes are treated in still another context because of the stringent environmental protection of critical natural areas and the costs associated with drilling for groundwater or counteracting the corrosive effects of salt water.

The amount of water avallable usually is expressed as a percentage of the ten-year, seven-day low flow. Most siting specialists and many river basin authorities prefer this measure because of 1 ts relation to extreme hydrologic events. The possibility of environmental damage exisıs, however, if nimerous users are promised allucations whose sum represents an over-commitment of a stream's low flow. In order to 
prevent this situation, several states require users to decrease or cease withdravals when established standards for required minimun low flow are reached. Mininum low flow standards for a stream are generally specified as $\exists$ fired required rate of runof $f$ or sometines are based on a minimum low flow per unit of drainage area. The Allegheny Power Service Corporation, for example, requires that ics plants should at no tine reduce streanflow below 0.15 cfs per square nile of drainage area. Usually, the lat ter method leads to larger aininum standards for streans serving large drainage areas and lower standards for snaller basins. In considering these required mirinum standards, utilities are most concerned uith the number of days that production likely will have to be curtailed. As an alternative to dependence on natural flows, water may be stored in utilityowned reservoirs to augment the stream during periods of low flow to a level where consunptive withdrawal can continue.

The water avallability factor was incorporated into the Maryland Data Base through a modeling effort described in A System for Regiona? Analysis of Water Availability by J. S. Jalbert and A. D. Shepherd. 16 The Water Analysis Syster (WAS) allows the user to Identify a geographic area by state, county, or latıtude-longituce frame and recall data on streamflow from the USGS jater tapes for all stream gaging stations within the area. Stations may he screened furti:s on the basis of drainage area size if it is desirable to reduce the amount of data or if only basins of a certain size are considered relevant to the study. A calculation of the probability of recurrence of low-flow phenomen is made for all selected stations.

In the Maryland Data Base, streams whose ilows are sufficient to support an additional 1000- to 1100-MWe power plant and still meet minimum standard low flows have been indicated. Stations unable to support stch a facility dependably and meet minimun flow standards are subjected to a reservolr model analysis. The reservolr model predicts the drawdown capacity required to support a given consunptive withdrawal, including estimated evaporative losses from the reservoir surface, while maintaining a specified minimus low flow. Daily flow values for the entire period of record drive the model. Streams which will support a 
power plant upon construction of a reasonable-size reservoir form a second category, and those which would require a reservoir of extraordinarily large drawdown capacity form a third. Proximities to all streans in the f..rst and second categories are calculated.

\subsubsection{Seisu'city}

Respondents invariably are highly concerned with the seisuic risk at a prospective nuclear site; this is a chief differentiation between criteria natrices for nuclear and fossil-fired plants. Most respondents combine regional levels of seismic activity and the susceptibility of local geologic structures to form this factcr. In practice, regional levels of seismic risk are readily available from the Niclear Regulatory Comission, 17 but the susceptibility of local geclogic structures depends upon land surface slope, climate, overburden thickness, and subsurface characteristics that are measured separately. A comprehensive factor model could be constructed from the raw variables in the Maryland Data Base, but as of now, seisaic activity and each of the structural variables are handled individually in the matrix.

\subsubsection{Presence of rare or endangerec'species}

Registered habitats of rare or endangered species are viened as totally unacceptable for power plant sites because of their current legal status. Most respondents assume tiat the plant will disrupt the habitat and that litigation will prohibit or delay its construction. It is noteworthy that, coincident with the NGP session, the TVA was embroiled in litigation which threatened to halt construction of the Tellico Dam because of its possible impact on the snall darter, a rare species of fish. Group participants from TVA were sensitive to this factor, and other group mewbers endorsed their high ranking. All respondents indicated that the species must be legally defined as rare or endangered in order to warrant the high importence weight. Pertinent data were obtained from the U.S. Arwy Corps of Fngineers. ${ }^{18}$ The habitats of other species of concern but not legally registe:ed as rare or endangered are considered in two separate factors dealing with impacts on aquatic and terrestrial biotz. These rank somewhat lower in importance. 


\subsubsection{Population density and distribution}

Population density is considered to be of great importance, particularly in regard to nuclear piants. Some respondents choose to list population distribution as i separate, though related, factor because of variations in potential radiation dosage with distance frov the piant or position relative to wind patterns. ('thers included distribution in their concepts of density. In either case there was a tendency to defer to "NRC guidelines." Ir poitut of fact, the NRC has sereral measures of population densily and distribution, and none is intended as a strict guideline. Variations in emergency evacuation plans and physiographic barrfers wst be considered in reaching a final decision on acceptable leveis of population density. Nevertheless, the site population factor (SPF) defined by NRC often is used by utilities as a quasi guideline in regional screening. 19

LUSP uses three measures of population density and distribution. A simple density is calculated from U.S. Census Enumeration District population totals. In addition, 5-nile and 30-aile SPF weighted densizy values (described in Sect. 2.1.1) serve as indicators of populatior. distribution around each potential site.

\subsubsection{Flood hazard}

The likelihood of flooding is cited consistently anong the nost important factors in nuclear power plant location. At the individual scale of site-specific analysis, calcliations of the probability of recurrence of various high rates of streamflow are required. However, most respondents do not feel that such detailed analyses are necessary at the regiona: scale. Generally the presence of a floodplain is taken as an indication of potential flooding, and no estinate of the magnitude is made. In the Maryland Data Base, floodplains are identified ty the presence of periodically inundated soils in the soils (prinary) variable.

\subsubsection{Geologic structure}

The importance of a cell's geologic foundation can be linked to construction and engineering characteristics as well as to 1 ts sultability 
for the continued stability of a built facility. Fault zones, karst topography, and areas with a high potential for lanislide obviously wst be considered in evaluating natural hazards. Other structural characteristics can be interpreted in terms of engineering traits which affect building costs. Bedrcck hardness, for example, can be included in a variable on blasting and grading requirements.

In practice the stability characteristics often are exclusionary, and the construction characteristics are of considerable importance though not exclusionary.

Six vartables have been devoted to geology in the Maryland Data Base. The first three list geologic formations in descending order of areal extent within the cell. These have been interpreted further as variables on overburden thickness and blasting, grading, or dredging requirements.

The sirth geology variable relates to aquifer productivity (the capacity of permeable layers of sand, gravel, or porous rock to hold or transmit groundwater). Most respondents rate this factor ach lower than other geologic traits, but enviromental impact statements for proposed facilities invariably contain an investigation of aquifers and aquicludes (inpermeable layers preventing seepage to an aquifer). This Is especially important for nuclear plants because of the potential for underground contanination of water suppiles in the event of radiation leakage.

\subsection{7 ำils}

The sotls factor is ranked highly by wost respondents, sometimes in combination: th geology and sowetimes standing alone. Wherever the geologic foundation is iudged to be of sufficient supportive strength, sofls are viewed primarily in terms cf construction characteristics. Solls with can be graded and packed easily, which drain rapidly, and which do not become plastic under woist conditions are ideal for alsost any type of building activity.

of all those in the data base, the soils varlable is, perhaps, the leact understood by most respondents. Confusion ardses in distinguishing 
soll depth from overburden thickness, which includes soils as well as weathered and crubling bedrock. Fur thermore, many respondents have difficulcy in interpreting soil characteristics in tems of their inpacts on corstruction costs.

In addition to inherent engineering qualities, soil type is often used as a proxy for other cell characteristics such as the presence of marsh, swanps, rock outcrops; floodplains, or beaches.

\subsubsection{Ylag-rade hazards}

Proxinity to alrports and industrial hazards such as maitions plants, refineries, and fuel storage tank farms is consicered a significant factor in calculating the likelihood of accidental release of radiation from a nuclear reactor. Emiromental impact statements contain a statistical analysis of the recurrence intervals for ajor disasters. The characteristics of both the reactor and the hazardous facility and the position of the plant relative to the facility enter into the calculation.

Such detailed calculations would be impractical in regional screening because of the large nuber of cells containing potential hazards which would have to be paired with cells representing potential sites. Moreover, the data base cannot contain meticulous information on each hazardous facility. Hence, proxinity to broadly defined hazardous installations in itself serves as an indication of a potential risk. Usually cells adjacent to afrports and other identifiable hazards are excluded frow candidate areas.

\subsubsection{Water quality}

Existing water quality is viewed as a determinant of costs associated with plant design and operation because of the corrosiveness of sone pollutants and the precipitate-producing tendency of others. Pure water can be recirculated through the cooling syste over and over, but highly polluted water quickly becomes too concentrated because of evaporative losses. Herbicides musi be added to all inconing water to prevent algal growth. All discharges must meet certain standards. Thus, 
operating costs are increased by the additional treatment required for the greater incake and discharge of water irce strians of poor quality. An alternative is to purify the intake vater, but this increases plant design as well as operating costs.

The ezisting quality of the strean relative to pollution control standards is of further interest because of possible inpacts on aquatic biota. If current effluents are at or near the naxim levels pernitted by the Environental Protection Agency or state and local inplementation standards, the power plant wst be designed to release almst no additional pollution. This is regarded as especially crucial if discharges wst be released into known fish spawning areas or water with high concentrations of juvenile fish and benthic acroinvertebraces. Trout streans, both stocked and natural, are deened critical regardless of existing water quality.

\subsubsection{Ocher regional screening factors}

Each noninal group listed wre than 30 factors applicable to cells of the size used in the MPPSP, and it would be inpractical to discuss then all in detail at this point. In sumary it can be said that they display renarkable insight and a concern for a broad spectrum of conceivable inpacts resulting fron a power plant. No doubt any would be placed much higher on the inportance scale if the same respondents or other interest groups were asked to emphasize other, wore specific siting objectives. 


\section{APPLICATION OF THE ORN LAND USE SCREENING PROCEDURE TO NORTHERN MARYLAND}

The ORM Land Use Screening Procedure (LUSP) was applied to the northarn Maryiand study area to identify candidate siting areas for nuclear and fossil-fired power plants, 1000 to 1100 the in size, each with three cocling options: cooling towers, cooling ponds, or oncethrough cooling systems. The six cocbinations of fuel anc cooling technologies were treated as separate facilities with separate siting criteria entered into the screening procedure. Hence, siting criteria were deterwined for each of the following facilities:

1. a 1000- to 1100-Mile nuclear power plant with cooling tower,

2. a 1000- to 1100-we nuclear power plant with cooling pond,

3. a 1000- to 1100-Mde nuclear pover plant with once-through cooling,

4. a 1000- to 1100-Me fossil-fired power plant witn cooling tower,

5. a 1000- to 1100-Me fossil-fired power plant with cooling pond, and

6. a 1000- to 1100-Mwe fossil-fired power plant with once-through cooling.

Each matrix of siting criteria has been applied to 31,234 cells of the Maryland Data Base for the northern eight counties. The record for each cell contains 52 variables; however, none of the siting specialists in the nominal group session felt that all 52 were relevant to siting considerations. The matrices utilized thus far have contained 29 or fewer variables.

The siting analysis for each facility type employs multiple criteria matrices as discussed in Chap. 3. Four respondent groups were asked to define these matrices for each of the four siting objectives. It was impractical to apply the entire procedure to each of the six facilities for all possible criteris matrices because this would require analysis of 96 separate sets of criteria. The final output consists of 22 criteria matrices distributed among the six facility types as appropriate to the sitinn analysis. 


\subsection{The Respondents}

Resource analysts in the Maryland Power Plant Sitir.g Progran are the users of this procedure in :ts application to northem Maryland. Elght of the twenty-two criteria matrices have been ceterninzd by that office for the purposes of this study. For either nuclear or fossilfired plants with cooling towers, the criteria deal with all four siting objectives: (1) Dinimization of construction and operating costs, (2) mininization of adverse socioeconomlc impact, (3) gininization of adverse ecologic impact, and (4) a composite of all siting objectives (see Table 2). ORNL staff nebers have prepared 14 additional matrices covering the six facility types for the ecologic and composite siting objectives.

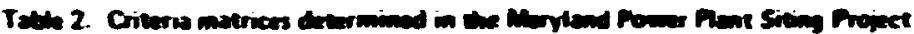

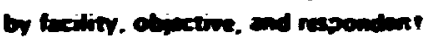

\begin{tabular}{|c|c|c|c|c|}
\hline Objective & $\begin{array}{l}\text { Minimization of construction } \\
\text { and apetating costs }\end{array}$ & $\begin{array}{l}\text { Minimization of adverse } \\
\text { ecologe impact }\end{array}$ & $\begin{array}{l}\text { Minimization of adverse } \\
\text { secioeconomic :mpact }\end{array}$ & $\begin{array}{l}\text { Composite } \\
\text { of all } \\
\text { obectives }\end{array}$ \\
\hline $\begin{array}{l}\text { Nuctear with } \\
\text { cooting tomer }\end{array}$ & PPSP & $\begin{array}{l}\text { PPSP } \\
\text { OANLO }\end{array}$ & PPSP & $\begin{array}{l}\text { PPSP } \\
\text { ORNL } \\
\text { Isi Nominal } \\
\text { Groupc } \\
\text { 2nd Nominal } \\
\text { Groupc }\end{array}$ \\
\hline $\begin{array}{l}\text { Nuclear with } \\
\text { cooling pond }\end{array}$ & & ORNL & & ORNL \\
\hline $\begin{array}{l}\text { Nuclear with } \\
\text { once-through } \\
\text { cooling }\end{array}$ & & ORNL & & OANL \\
\hline $\begin{array}{l}\text { Fossil-fired } \\
\text { with cooling } \\
\text { rower }\end{array}$ & PPSP & $\begin{array}{l}\text { PPSP } \\
\text { ORNL }\end{array}$ & PPSP & $\begin{array}{l}\text { PPSP } \\
\text { ORNL }\end{array}$ \\
\hline $\begin{array}{l}\text { Fossil.fired } \\
\text { with cooling } \\
\text { pond }\end{array}$ & & ORNL & & OANL \\
\hline $\begin{array}{l}\text { Fossil-fired } \\
\text { with once-through } \\
\text { cooling }\end{array}$ & & ORNL & & ORNL \\
\hline
\end{tabular}


Two separate groups of siting specialists were asked to deternine siting criteria in an application of the Nominal Group Process. The recise makeup and operation of these panels are discussed in : $: \cdots$

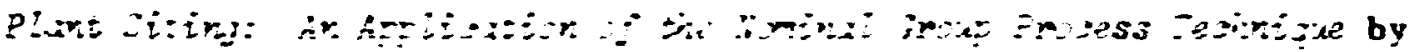
A. H. Voelker. 12 Each was asked to focus on auclear power plints with cooling tomers for a composite of all siting objectives. The first group contained representatives froe ORW, TVA, and the inaryland Power Plant Siting Program. The second consisted of differeat representatives of these sace organizations plus one neber from the Allegheny Power Service Corporation and one from the University of Illinois.

Because of tive constraints and the desire not to inconvenience participants, the two groups were asked to provide inportance weights only. To complete the necessary entrix, orkl personnel produced compatibility indices to be used in suitability calculations for both nominal groups.

\subsection{Comparisons of Criteria Matrices}

The purpose of providing multiple matrices is to allow conparisons and cross-checks between various facilities, respondents, and sbjectives. The following types of comparisons are useful in analyzing the input data for each watrix:

a. comparisons between different objectives for a given facility,

b. comparisons between different respondents for a given facility and objective,

c. comparisons between different facilities for a given objective.

To avold the confusion of describing all 22 matrices, cercain sets $\mathbf{w 1 1}$ be selected for comparison. The remaining portions of this chapter discuss such coaparisons using the representative criterla matrices as 1. Iustrative examples.

\subsubsection{Criteria for a fossil-fired power plant with cooling tower: a comparison among siting objectives}

Importance weights obtained for four different siting objectives are displayed in Table 3. Each set is distinctively different from all 


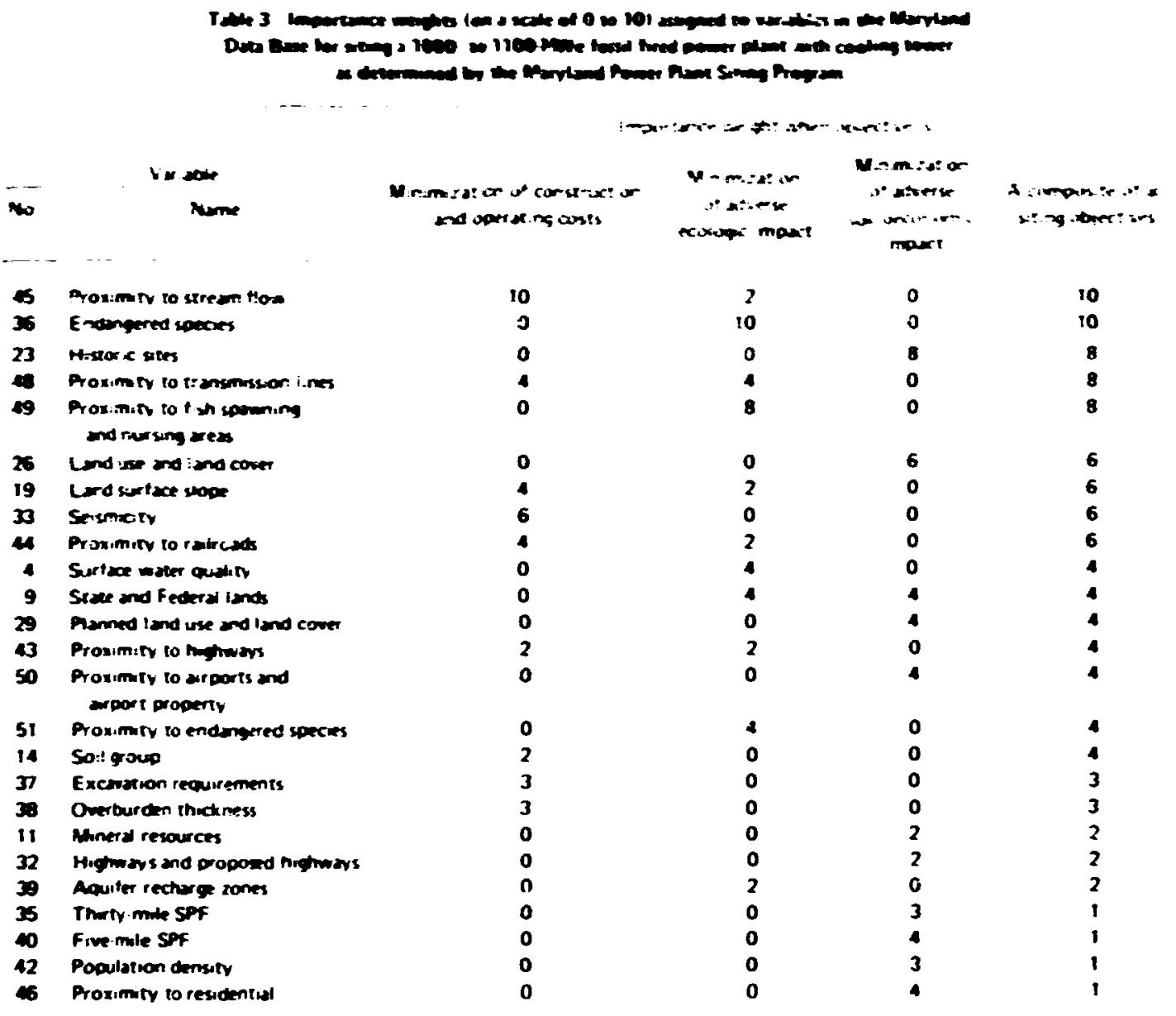

cthers, and the composite objective incorporates the weights assigned to the three individual objectives. As one might expect, physical factors such as proxiaity to streamflow and seismicity rank high in the cost minimization matrix, while historic sites, land use, and population factors rank high on the socioeconomic matrix. (The importance weight for the population factor is divided between three population variables whose total weight is 10.) Endangered species and designated natural areas head the list on the ecologic matrix.

For each highly incompatible category or value of a highly important variable a decision must be made by the respondent either to assign an exclusion index $(-1)$ or a minimum compatibility index $(0)$. This decision can have a dramatic effect on the final szores because the assignment of numerous exclusions reduces the number of potential sites while increasing the average scoite of the cells remaining in the calcu- 
lation. Excluded categories and values serve vell as a means of corparing the compatibility components of various criteria matices. The ent ire set of cuspatibility indices presented in Appendix is too cumbersome for a detailed comparison.

Table 4 displays the exclusion factors prepared by Maryland personnel for four different criceria matrices. It is evident that the responients were distinguishing between the three individual objectives, since no two matrices contain the same exclusions. The composite atrix contains the accunulated exclusions of all other matrices; however, it is quice possible for a category to be perceived as exclusionary for a specific objective and merely of low comatibility in the composite matrix. This results from the implicit importance ascribed to the objective itself in preparing the composite matrix. The accumulation of exclusions from all objectives, as in this example, demonsträtes a willingness to consider all objectives equally.

\begin{tabular}{|c|c|c|c|c|c|c|}
\hline No & $\begin{array}{l}\text { Voristie } \\
\text { Nome }\end{array}$ & $\begin{array}{l}\text { Corespery or } \\
\text { rempe of walues }\end{array}$ & $\begin{array}{l}\text { Minimization } \\
\text { of construetion } \\
\text { and operating } \\
\text { cosis }\end{array}$ & $\begin{array}{l}\text { Minimization } \\
\text { of adverse } \\
\text { ecologic } \\
\text { impici }\end{array}$ & $\begin{array}{l}\text { Minimixation } \\
\text { of adverse } \\
\text { sociocionomic } \\
\text { impaci }\end{array}$ & $\begin{array}{l}\text { A composite } \\
\text { of sil siting } \\
\text { objectives }\end{array}$ \\
\hline 9 & $\begin{array}{l}\text { State and } \\
\text { Federat lands }\end{array}$ & $\begin{array}{l}\text { Department of the } \\
\text { interior. Fish and } \\
\text { Wildife. and Foresis } \\
\text { and Parks }\end{array}$ & & & $x$ & $x$ \\
\hline 19 & $\begin{array}{l}\text { Lind surlace } \\
\text { slope }\end{array}$ & $200_{n} \sin 2$ & $x$ & $x$ & & $x$ \\
\hline 26 & $\begin{array}{l}\text { Land use } \\
\text { and land } \\
\text { sover }\end{array}$ & $\begin{array}{l}\text { Urben activity. water } \\
\text { eover, barren land }\end{array}$ & & & $x$ & $x$ \\
\hline 29 & $\begin{array}{l}\text { Planned land use } \\
\text { and land } \\
\text { cover }\end{array}$ & $\begin{array}{l}\text { Urban acfivity. water } \\
\text { eover, burren land }\end{array}$ & & & $x$ & $x$ \\
\hline 32 & $\begin{array}{l}\text { Highwavs and } \\
\text { proposed highways }\end{array}$ & $\begin{array}{l}\text { Existing ines and four lane } \\
\text { and interstate and } \\
\text { major intersections }\end{array}$ & & & $x$ & $x$ \\
\hline 45 & $\begin{array}{l}\text { Proximity in } \\
\text { stream flow }\end{array}$ & $\begin{array}{l}\text { Proximity greder } \\
\text { than } 16.6 \mathrm{~km}\end{array}$ & $x$ & & & $x$ \\
\hline 51 & $\begin{array}{l}\text { Proximity to } \\
\text { endangered } \\
\text { spreies }\end{array}$ & Proximity of $0-0.6 \mathrm{~km}$ & & $x$ & & $x$ \\
\hline
\end{tabular}




\subsubsection{Criter ia for a nuclear fower plant with cooling tower:}

a conparison anong respondents

A fundamental reason for requiring nuerous criteria matrices is the expected variation between the values and judgents of different groups. Tab!e $;$ indicates that great differences can be obtained from different respondents even for the sase facility and objective. Three of the four respondent grrups rated seiseicity, proximity to water, and presence of endangered species at 10. Surprisingly, the fourth group relt that potent:al subsidence associated with deep nining of aineral resources was a wre inportant consideration than any of those listed above.

For any given variable the weight can vary considerably anong the four respondents. In fact, no variable received exactly the sane weight from all respondents, only a few were perceived by all respondents to be of approximately the same inportance, and sore variables ranged as nuch as eight or nine points between their maxinum and ninimu assignments. These wide variations could bring into question the validity of the quancification if it were not for the probability that such variations actually do exist among siting specialists. Certainly disagreement exists anong "experts" in any field. The advantage here ts that their values are stated explficitly so that comparisons can be made.

Table 6 reveals further variation in the respondents' atticudes toward assigning exclusions. The three respondents were able to agree only on exclustons for certain land-use and land-cover categories, including urban uses and water bodies. 


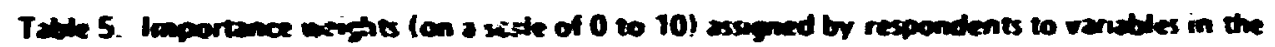

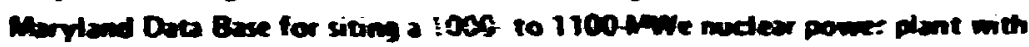
cochng tower with a composise siting chjective

\begin{tabular}{|c|c|c|c|c|c|}
\hline No. & $\begin{array}{c}\text { Variable } \\
\text { Nane }\end{array}$ & PPSP & $\begin{array}{c}\text { Fisi } \\
\text { Niom:nai } \\
\text { Group }\end{array}$ & $\begin{array}{l}\text { Second } \\
\text { Nomina: } \\
\text { Group }\end{array}$ & ORNL \\
\hline 33 & Seismiciry & 10 & 10 & 7 & 10 \\
\hline 45 & Proximity to stream flow & 10 & 10 & 9 & 10 \\
\hline 36 & Endangered species & 10 & 10 & 7 & 10 \\
\hline 17 & Natural teatures & 10 & 7 & 5 & 10 \\
\hline 23 & Historic sites & 8 & 5 & 8 & 6 \\
\hline 48 & Proximity to transmission lines & 8 & 7 & 4 & 2 \\
\hline 49 & $\begin{array}{l}\text { Proximity to fish spawning and } \\
\text { nursing areas }\end{array}$ & 8 & 8 & 9 & $\mathbf{0}$ \\
\hline 52 & Proximity to natural features & 8 & 7 & 3 & 2 \\
\hline 26 & Land use and land cover & 6 & 6 & 9 & 10 \\
\hline 19 & Land surface slope & 6 & 4 & 8 & 8 \\
\hline 4 & Surface water quality & 4 & 8 & 9 & 8 \\
\hline 9 & State and Federal lands & 4 & 4 & 7 & 8 \\
\hline 29 & Planned land use and land cover & 4 & 0 & 0 & 0 \\
\hline 37 & Excovarion requirements & 4 & 5 & 5 & 0 \\
\hline 38 & Overburden thickness & 4 & 2 & 3 & 0 \\
\hline 40 & Five-mile SPF & 4 & 4 & 3 & 0 \\
\hline 43 & Proximity to highways & 4 & 6 & 3 & 6 \\
\hline 44 & Proximity to railroads & 4 & 6 & 4 & 8 \\
\hline 46 & Proxituiv to residential & 4 & 6 & 2 & 10 \\
\hline 50 & $\begin{array}{l}\text { Proximity to airports and airport } \\
\text { property }\end{array}$ & 4 & 8 & 8 & 8 \\
\hline 51 & Proximity to endangered species & 4 & 10 & 2 & 6 \\
\hline 42 & Population density & 3 & 9 & 7 & 10 \\
\hline 35 & Thirty-mile SPF & 3 & 4 & 2 & 0 \\
\hline 11 & Mineral resources & 2 & 8 & 10 & 4 \\
\hline 14 & Soil group & 2 & 2 & 5 & 6 \\
\hline 32 & Highways and proposed highways & 2 & 6 & 3 & 4 \\
\hline 39 & Aquifer recharge zones & 2 & 3 & 4 & $\mathbf{0}$ \\
\hline 7 & Transportation and transmission & $\mathbf{0}$ & 6 & 3 & 4 \\
\hline 34 & Fish spawning and nursing areas & $\mathbf{0}$ & 8 & 9 & 0 \\
\hline 47 & Proximity to agricultural land use & $\mathbf{0}$ & 6 & 0 & 4 \\
\hline 12 & Water and sewer facilities & 0 & $\mathbf{0}$ & 0 & 2 \\
\hline
\end{tabular}

apPSP _ Maryland Power Plant Siting Program.

bORNL - Oak Ridge National Laboratory. 


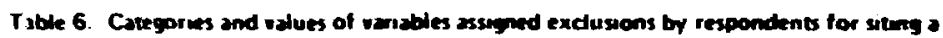
1000. to 1100 - inwe nucter pown plant with coolong tomer

with a compossite suthe objective

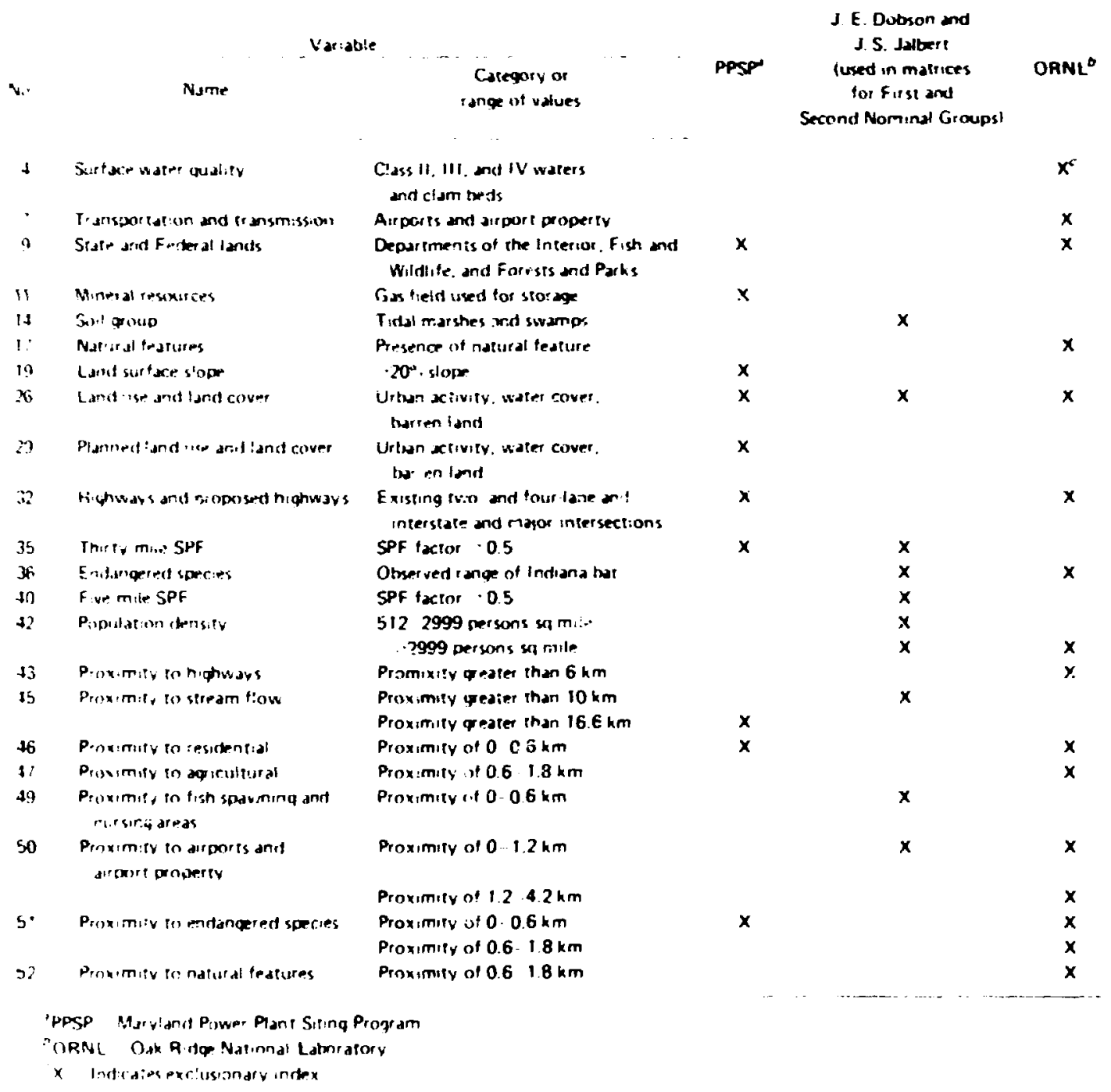

\section{2.' Criteria for a nuclear or fossil-fired power plant: a comparison between fuel options}

The considerations which influence a utility company's decision i egarding the choice of fuel types for a given facility are too complex to be solved in a screening algorithm of the type used in LUSP. They inciude questions of fuel cost, reliability, and public acceptance which generally are not sulted to inclusion in an extensive geocoded data base either because the information can be collected only through streriuous site-specific analyses or because it would require continuous updating. 
Presumably many land parcels would be suited to either a nuclear or fossil-fired facility in terms of their capability to support it physically and to bear the social, ecologic, and econonic inpacts. Tables 7 and 8 show that the same importance weights and exclusions are assigned for most variables. There are basic distinctions between the matrices where population densities and seismic $x_{\text {s }}$ sk are concerned. For all

Table 7. Importance meights (on a scale of 0 to 10) assigned to variables in the Maryland Data Base for siting a 1000- to 1100Awe power plant with a composite siting objective as determined by the Maryland Power Pant Siting Program

\begin{tabular}{|c|c|c|c|}
\hline \multicolumn{2}{|r|}{ Variable } & \multirow{2}{*}{$\begin{array}{l}\text { Nuclear power } \\
\text { plant with } \\
\text { cooling tower }\end{array}$} & \multirow{2}{*}{$\begin{array}{l}\text { Fossil-fired } \\
\text { power plant with } \\
\text { cooling tower }\end{array}$} \\
\hline No. & Name & & \\
\hline 33 & Seismicity & 10 & 6 \\
\hline 45 & Proximity to stream flow & 10 & 10 \\
\hline 36 & Endanger ed species & 10 & 10 \\
\hline 17 & Natural resources & 10 & 10 \\
\hline 23 & Historic sites & 8 & 3 \\
\hline 48 & Proximity to transmission lines & 8 & 8 \\
\hline 49 & $\begin{array}{l}\text { Proximity to fish spawning and } \\
\text { nur ing areas }\end{array}$ & 8 & 8 \\
\hline 52 & Proximity to natural features & 8 & 8 \\
\hline 26 & Land use and land cover & 6 & 6 \\
\hline 19 & Land surface slope & 6 & 6 \\
\hline 4 & Surface water quality & 4 & 4 \\
\hline 9 & Stare and Federai lands & 4 & 4 \\
\hline 29 & Planned land uses and land cover & 4 & 4 \\
\hline 37 & Excavation requirements & 4 & 3 \\
\hline 38 & Overburdr:n thickness & .1 & 3 \\
\hline 40 & Five-mile SPF & 4 & 1 \\
\hline 43 & Proximity to highways & 4 & 4 \\
\hline 1.4 & Proximity to railroads & 4 & 6 \\
\hline 46 & Proximity to residential & 4 & 1 \\
\hline 50 & $\begin{array}{l}\text { Proximity to airporis and airport } \\
\text { property }\end{array}$ & 4 & 4 \\
\hline 51 & Proximity to endangered species & 4 & 4 \\
\hline 42 & Population density & 3 & 1 \\
\hline 35 & Thirty.mile SPF & 3 & 1 \\
\hline 11 & Mineral resources & 2 & 2 \\
\hline 14 & Soil group & 2 & 4 \\
\hline 32 & Highways and proposed highways & 2 & 2 \\
\hline 39 & Aquifer recharge zone & 2 & 2 \\
\hline
\end{tabular}




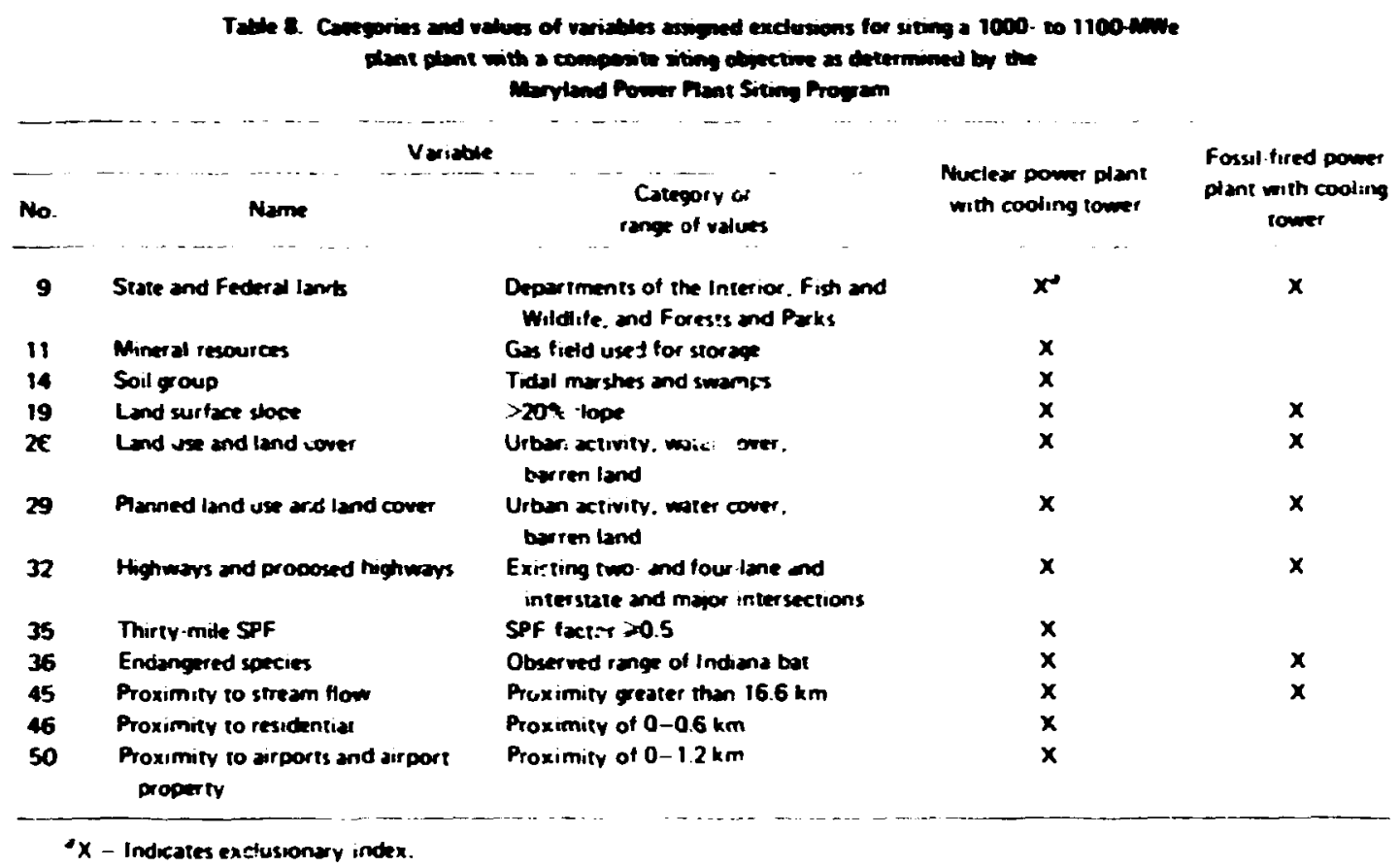

variables dealing with these factors the standards for nuclear plants are much more stringent. It shouid be noted, however, that air pollution standards for fossil-fired plants of ten have the same effect of forcing the factlities away from large urban settlewents. 20

The respondent also indicated a difference in transportation and accessibility factors between the two fuel types. Proxinity to railroads was viewed as slightly more important for fossil-fired plants because of the need for frequent shipments of fuel (most responde... anticipated that fossil-fired plants would use coal). On the oth:r iand, barge access was considered to be somewhat more desirable for nuclear plants because of the difficulty of transporting the reactor pressure vessel overland during the initial construction phase. Airports were felt to be particularly hazardous for nuclear plants.

\subsubsection{Criteria for a fossil-fired plant with the objective of minimizing adverse ecologic impact: a comparison among cooling system oprions}

Most respondents express difficulty in distinguishing be:ween the criteria for various cooling system options at the regional and local screening levels. Table 9 reveals only slight differences in the 
Table 9. Importance weighes (on a seate of 0 to 10 ) assigned to variables in the Maryland Dots Bese for siting 1000- to 1100 - wnve fossil-fired poner plants with various iypes of cooling systums with the objective of minimizing adverse ecologic impact as determined by ORNL.

\begin{tabular}{|c|c|c|c|c|}
\hline \multicolumn{2}{|r|}{ Variable } & \multirow[b]{2}{*}{$\begin{array}{l}\text { Cooling } \\
\text { tower }\end{array}$} & \multirow[b]{2}{*}{$\begin{array}{l}\text { Cooling } \\
\text { pond }\end{array}$} & \multirow[b]{2}{*}{ Once-through } \\
\hline No. & Name & & & \\
\hline 17 & Natural features & 10 & 10 & 10 \\
\hline 36 & Endangered species & 10 & 10 & 10 \\
\hline 39 & Aquifer recharge zones & 10 & 10 & $\mathbf{9}$ \\
\hline 4 & Surface water quality & 9 & 9 & 10 \\
\hline 51 & Proximity to endangered species & 9 & 9 & 9 \\
\hline 52 & Proximity to natural features & 9 & $\mathbf{y}$ & 9 \\
\hline 9 & State and Federal lands & 8 & 8 & 8 \\
\hline 26 & Land use and land cover & 8 & 8 & 8 \\
\hline 14 & Soil group & 7 & 7 & 5 \\
\hline 49 & $\begin{array}{l}\text { Proximity to fish spowning and } \\
\text { nursing areas }\end{array}$ & 7 & 7 & 8 \\
\hline 19 & Land surface slope & 6 & 6 & 5 \\
\hline 29 & Planned land use and land cover & 6 & 6 & 6 \\
\hline 42 & Population density & 6 & 6 & 6 \\
\hline 13 & Forest type & 5 & 7 & 5 \\
\hline 45 & Proximity to stream flow & 4 & 4 & 4 \\
\hline 11 & Mirieral resources & 3 & 3 & 3 \\
\hline 23 & Historic sites & 2 & 1 & 1 \\
\hline 43 & Proximity to highways & 1 & 1 & 1 \\
\hline 44 & Proximity to railroads & 1 & 1 & 1 \\
\hline 48 & Proximity to transmission lines & 1 & 1 & 1 \\
\hline
\end{tabular}

importance weights assigned in each matrix. The majority of variables receive precisely the same weight for all three cooling systems, and in no case do the weights differ by more than 2 points. Table 10 shows even less distinction in the exclusions granted to the three facilities. The only difference is in the categories indicating polluted trout streams, where the respondent feels that fish should not be sibjected to the greater intake of once-through cooling systens regardless of the condition of the scream. 


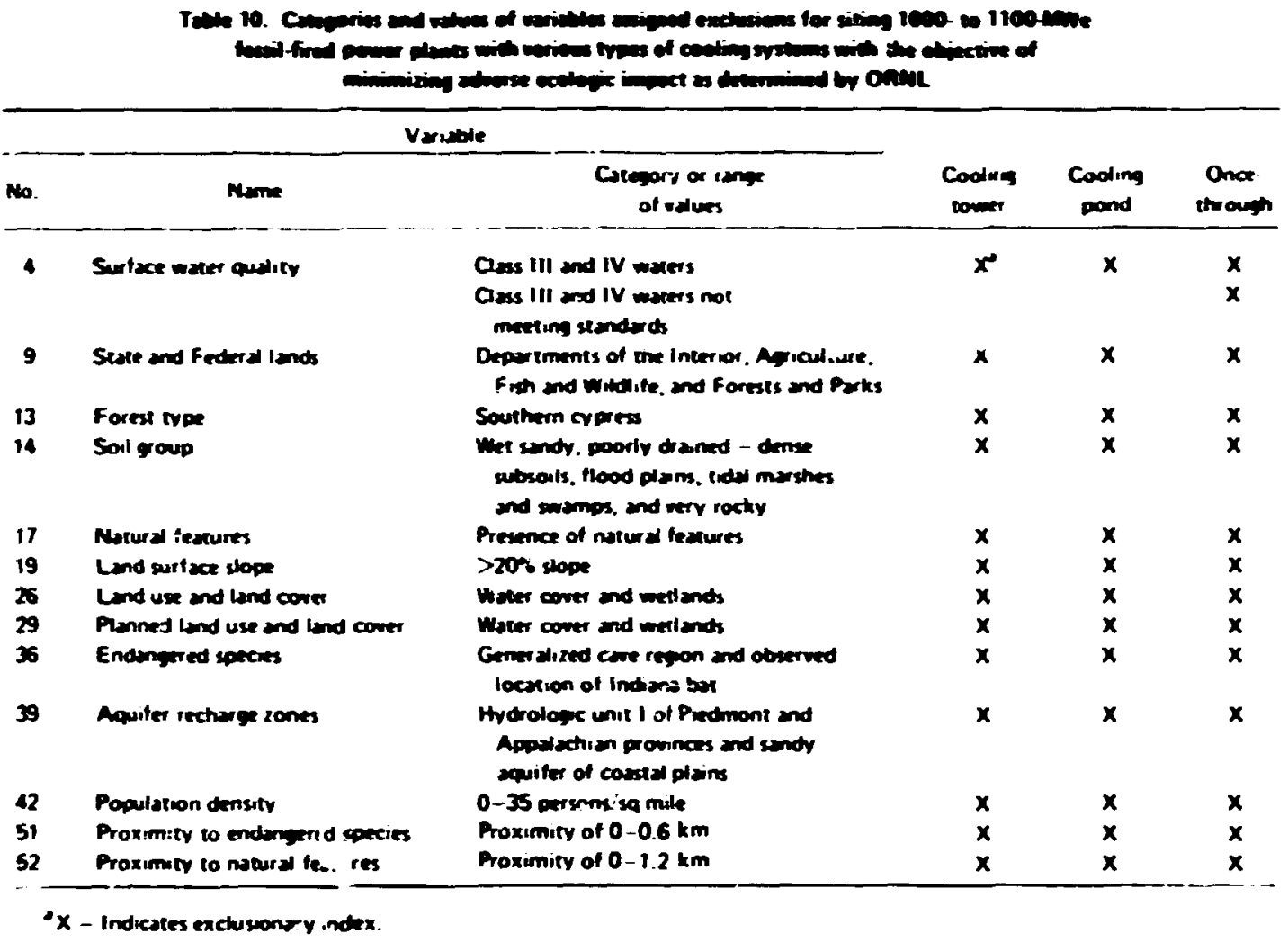

\subsection{The Utility of Multiple Matrices}

The examples discussed in tinis chapter and other criteria atrices exanined at ORNL support the conclusion that at the regional and local screening levels, wost respondents can distinguish clearly between different siting objectives. The distinction between criteria for different fuel types also is great enough to warrant the application of separate matrices. However, the ability of most respondents to distinguish between various cooling options with the current data coverage is doubtful. Additional refinement of the streanflow and soll type variables is required.

Perhaps the most inportant conclusion is that dif:-rences anong respondents are sizable even when the type of facility and siting objective are the same. This suggests that ft is essential to consult nunerous interest groups in establishing criteria for regional and local screening. A further test of this conclusion is the analysis of the spatial distributions of candidate areas obtained fron different aatrices, and these are discussed in Chap. 5 . 


\section{AMALYSIS OF THE CELI SUITABILITY SCORES}

The criteria matrices are applied to the data base according to the formula described in Sect. 2.2.2, and suitability scores are obtained for cach cell. The suitability calculation progran automatically produces histograns and calculates statistical momentescribing the frequencies of cell suitability scores. An additional progran is available to map the spatial distribution of scores obtained from each merix. 7 This chapter focuses on statistical and spatial analyses of cell suitability scores and the interpretation of candidate-area aps.

\subsection{Statistical Analysis}

The prinary purpose of the statistical inforation is to serve as a guide in deciding which ranges of scores for meaningful classes for candidate-area selection. Usually it is necessary to know the frequency and central tendency of the scores to deteraine which ranges should be mapped.

The histogram provides a quick check on the operation of the screening algorithe. At a glance the user can detect certain types of errors evident in the range and skewness of the distribution. For example, a range of scores from 0 to 5 on the histogram aight indicate that the user had substituted a 0 to 5 scale in one of the atrices for the usual compatibility range of 0 to 10 . This would alert the user that one set of scores was not precisely comparable with ochers enploying the usual range.

More important, the histogran creates a visual impression of the strictness with which respondents have assigned coapatibility indices. In a comparison of the scores obtained from different respondents for the same facility (and objective), a distribution abnorwally skeved toward the upper range indicates that the respondent has been wlling to grant higher compatibility indices in the original atrix. Whether this results frod a genuinely wore lenient siting policy or frov a different understardir.g of the data or screening procedure should be taken into account in mapping candidate areas. 
The user can define candidate areas by any range of scores he chooses, but it is recomended that the choice should take the overall distribution and the value of the mean into consideration. In the MPPSP, candidate areas consist of cells whose scores are one or wre standard deviations above the mean. This compensates for any variation in the strictness with which the comatibility indices were assigned because the mean is influenced by the skemess of the overall distribution. Furthenore, it assures that a constant proportion of the cotal distribution will be defined in each set of suitability scores. Cells receiving exclusions are not included in the calculation of the mean and standard deviation. Fron the 22 sets of scores obtained thus far it is apparent that the histogran usually approximates a noral distribution of scores around the mean.

\subsection{Spatial Analysis}

The themeic apping progran designed to accompany the LUSP produces line-printer aps with typed titles and legends in a standardized formet. Programing instructions and illustrations can be found in $A$ Cell-Based Land Use Scroening Procedure for Regional Siting Analysis. 7 This particular forn of graphic output was chosen because the resultant eaps are sufficient for analytical purposes and can be run cheaply on relatively sall computer systems. It was anticipated tiat many potential users would not possess highly sophisticated graphic capabilities.

The line-printer maps are iot well suited for display in published reports. Hence the maps contained in this document were produced on a Calcomp plotter by the Computer Sciences Division of ORRL. Both types of maps can be used to display raw variables, proxinity variables, or suitability scores with up to 30 symols representing different categories defined in the legend.

Maps displaying ranges of suitability scores are essential in the spatial analysis of the scores obtained from the various criteria atr!ces. The remainder of this section is organized for ease of corparison between the scores obtained from different respondents for differing objectives and facilties. 


\subsubsection{Candidate areas for a fossil-fired power plant: a comparison among siting objectives}

The role of various siting objectives in selecting candidate areas is illustrated in the maps obtained fron matrices developed by the Maryland Power Plant Siting Program. When cost ainieization is the overriding objective, wost of the coastal and riverine areas in the study region are defined as candidate areas (Pig. 3). Considering that cost of the electrical demand is in the eastern malopolis including Baltinore and Washington, D.C., locations on Chesapeake Bay seen especially attractive. The Monocacy and totonac Rivers in Frederick County form extensive candidate areas within $65 \mathrm{~km}$ (40 ailes) of Baltinore. These, too, would be near the electrical load center and would be within a reasonable conuting distance of the heavy construction labor forces in Baltinore and Washington, D.C. Scattered sites can be seen also along the upper reaches of the Potonac in Washington, Allegany, and Garrett Counties, with heaviest concentrations near Cuberland, Maryland. However, these must be viewed with sispicion because of the lack of geographic data beyond the state boundary.

The distribution of suitable candidate areas for a socioecononic objective is substantially different from that discussed above (Fig. 4). Alnost the entire eastern one-third of the atudy region is eliminated because of characteristics associated with its high population concentration. The extent of the candidate areas increases to the west as population densities decline, with noticeable gaps near the cities of Frederick, Hagerstom, and Cumberland.

Ecologic considerations, on the other hand, cause the distribution of candidate areas to shift away from the sparsely populated, more natural and scenic areas of the west (Fig. 5). Sinilarly, most of the land near Chesapeake Bay is elininated because of natural and scenic qualities. The resulting candidate areas are concentrated in areas of internediate population in the central and eastern counties, with a few scattered cells near th: urban areas of the west.

The distribution of candidate areas obtained for a composite of all siting objectives appears to be a compromise of the three individual objectives (Fig. 6). The largest concentration is in the center of the 


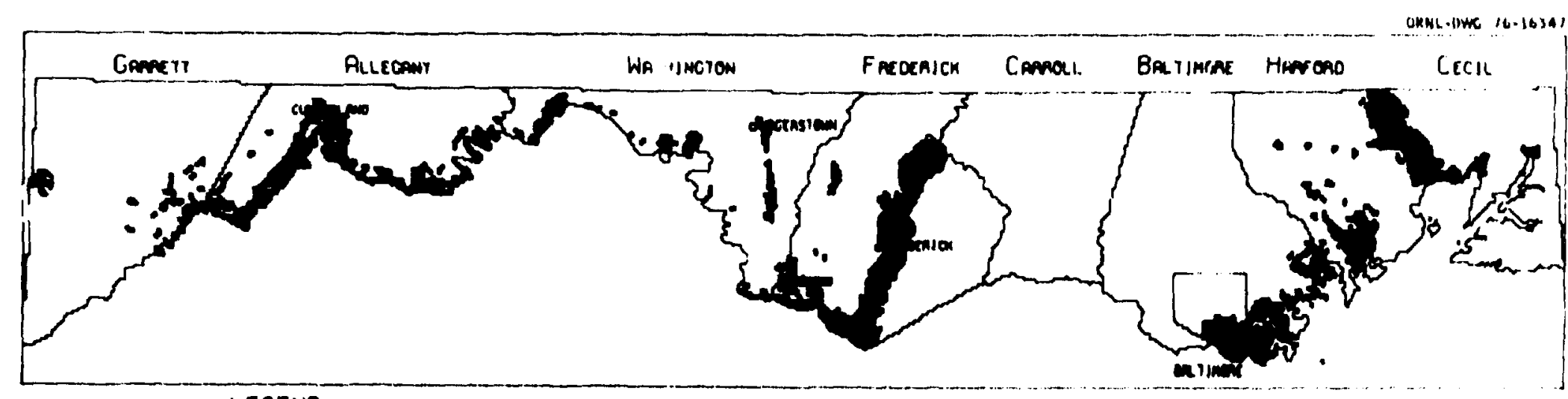

\section{LECEND}

CANDIDATE AREAS

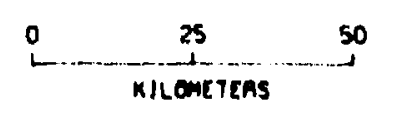

LOW \& IIEDIUM SCORES

PnoOuceo or hloce

GCocmpric. DaYA STSIEMS

F18. 3. Candidate areas for a fosall-fired power plant with cooling tower in northern Maryland, 1976. Siting objective: minimization of construction and operating costs. Respondent: Maryland Power Plant stting Program. Number of variables in calculation: 27. 


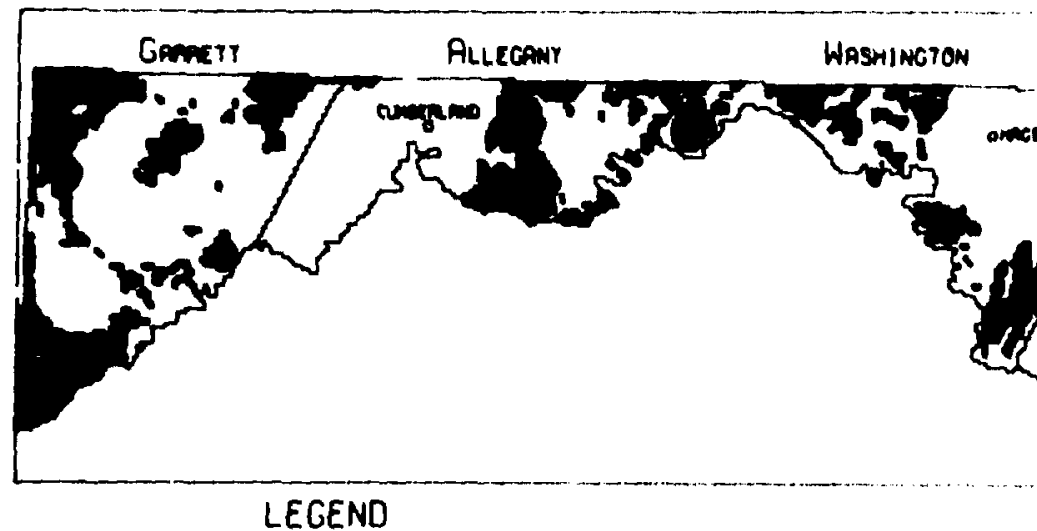

\section{LEGEND}

CANOIDATE AREAS

LOW \& MEDIUM SCORES
PAOOUCEO OT OAN AIOCE GEDCAPAHIC LATA STSTEMS

F18. 4. Candidate areas for a fossil-fired power plant with cooling tower in northern Maryland, 1976. Siting objective: minimizacton of adverse soctoeconomic Impact. Respondent: Maryland Power Plant Siting Program. Number of varlables in calculation: 27. 


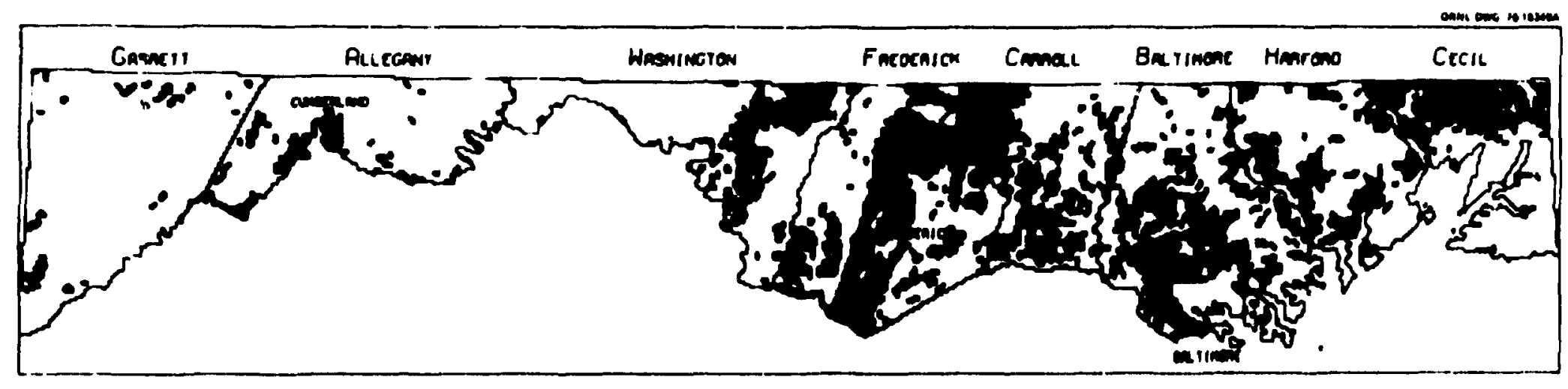

\section{LEGEND}

CANDIDATE AREAS

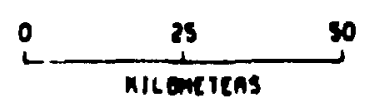

LOW \& MEOIUM SCORES

meaceo or orm Mloct

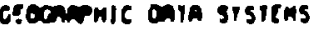

F18. 5. Candidate areas for a fossil-fired power plant with coolf.ng tower In northern Maryland, 1976. Siting abjective: minimization of adverse ecologic impact. Respondent: Maryland Power Plant Siting Program. Number of varlables in calculation: 27. 


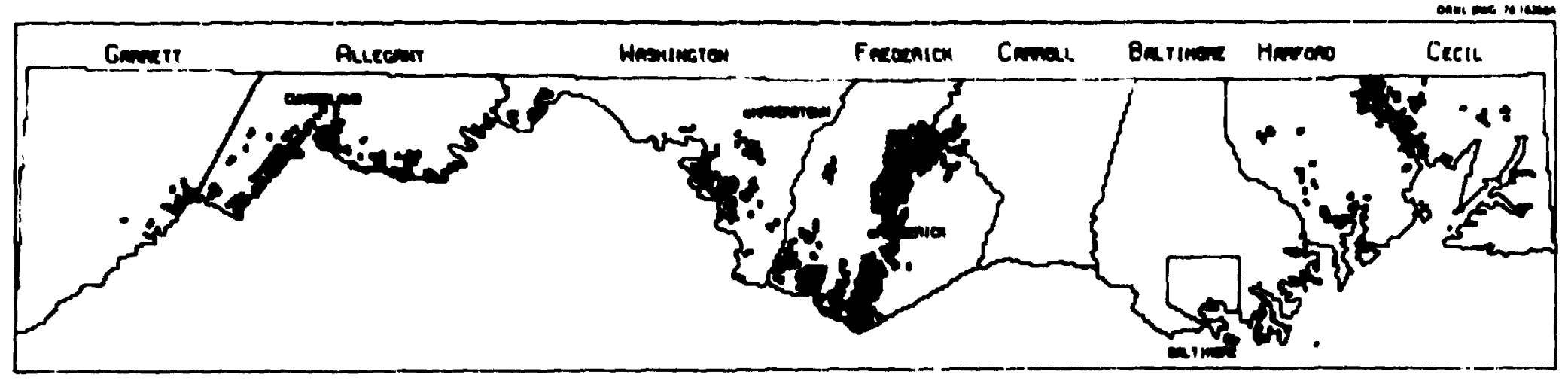

\section{LEGENO}

CANDIDATE AREAS

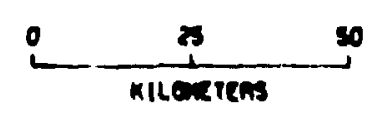

LOW \& MEOIUM SCOAES

meacto of on Alcee aconmic onis srsiens

F18. 6. Candidate areas for a fossil-fired power plant with cooling tower In northern Maryland, 1976. Siting objective: composite of all objectives. Respondent: Maryland Power Plant S1ting Program. Number of variables in calculation: 27 . 
study region, where all three previous maps have shown candidate areas. Except for those near the Monacacy River and the upper Potonac near Cure erland, most of the high-scoring cells form clusters too small to be utilized as actual sites. In the east only one cluster on the Susquehanna River appears to be large enough to constitute a viable candidate site without acquiring adjacent lower-scoring cells.

\subsubsection{Candidate areas for a nuclear or fossil-fired power plant: a comparison between fuel types}

A comparison between the candidate areas obtained for nuclear vs fossil-fired plants by the Power Plant Siting Program for each siting objective shows that their spatial distributions are almost identical (Figs. 3-10). Although several distinctions between fuel types were noted in the criteria matrices, the more stringent standards for nuclear plants have had almost no effect on the overall distribution of highicoring cells.

In going fron the candidate areas for fossil-fired plants to those for nuclear plants, it appears that a few scattered cells are eliainated in the east, while concentrations have become slightly heavier in the west. In addition, a few cells near urban centers have been dropped. In other words, some of the socioecononic impacts anticipated for nuclear plants have forced the user to risk slightly greater ecologic inpact by opting for more remote areas. In this particular example it is doubtful that the distiriction is great enough to justify the additional effort involved in treating the as separate facilities. It is possible, however, that the spatial distributions might differ substantially in other parts of the United States, especially in locations where seismic risk varies considerably within the region.

Much greater distinction between fuel types is apparent in the maps prepared at ORNL with the objective of minimizing adverse ecologic impact (Figs. 11 and 12). While the candidate areas for a fossil-fired plant are not unlike those produced by the fower Plant Siting Program for the same facility and objective (Pig. 5), the ecologic criteria for a nuclear plant are so stringent that only a few candidate areas remain. 


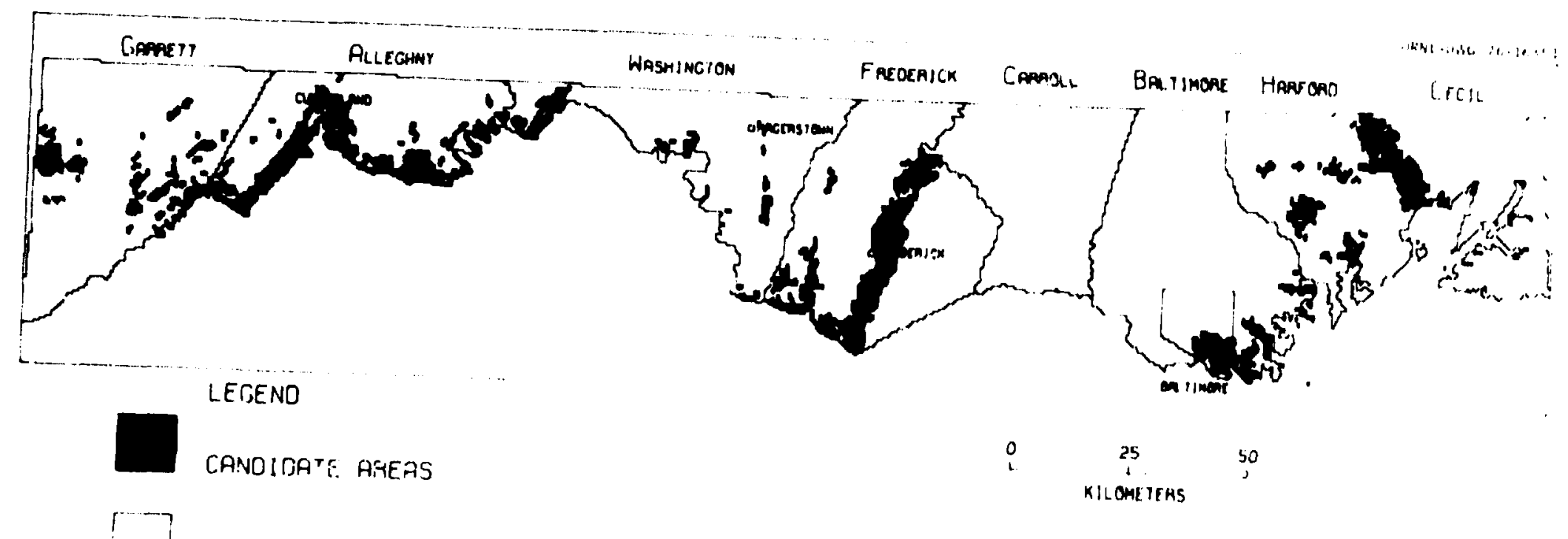

LOW \& MEJIUM SCORES

tower in northern Maryland, 1976 a nuclear power plant with cooling construction and operating 1976. Siting objective: minimization of

Siting Program. Number of variables in calculataryland Power Plant 


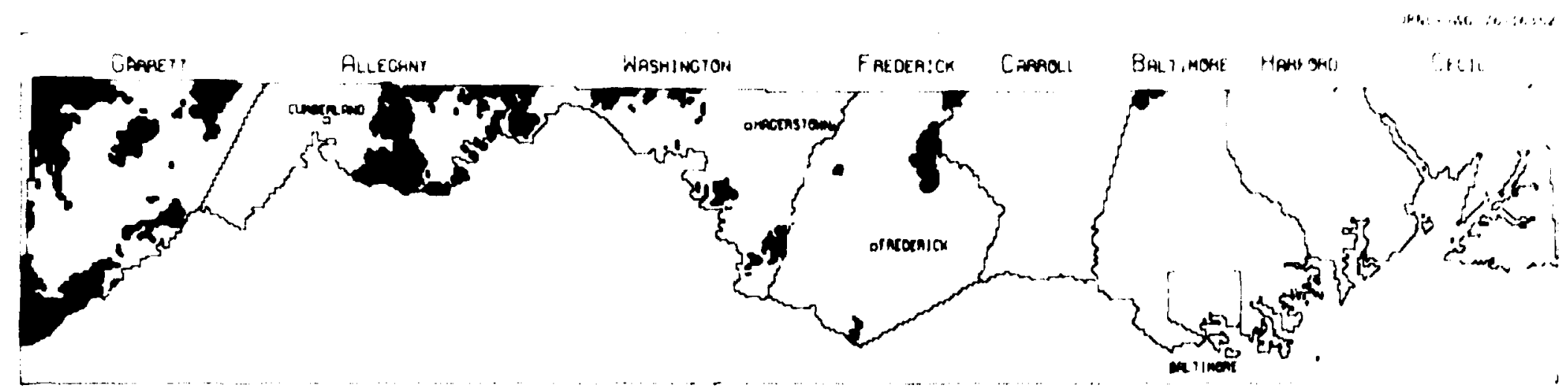

LEGEND

CANUIOATE AREAS

0
25
2

50

LOW \& MEDIUM SCORES

PROONCD BY RIDGE CEOCAAPHIC OHTA STSTEMS

F18. 8. Candidate areas for a nuclear power plent with cooling tower in northern Marylaud, 1976. Siting objestive: minimization of adverse socioeconomic Impact. Respordent: Maryland Power Plant Siting Program. Number of variables in calculation: 27. 

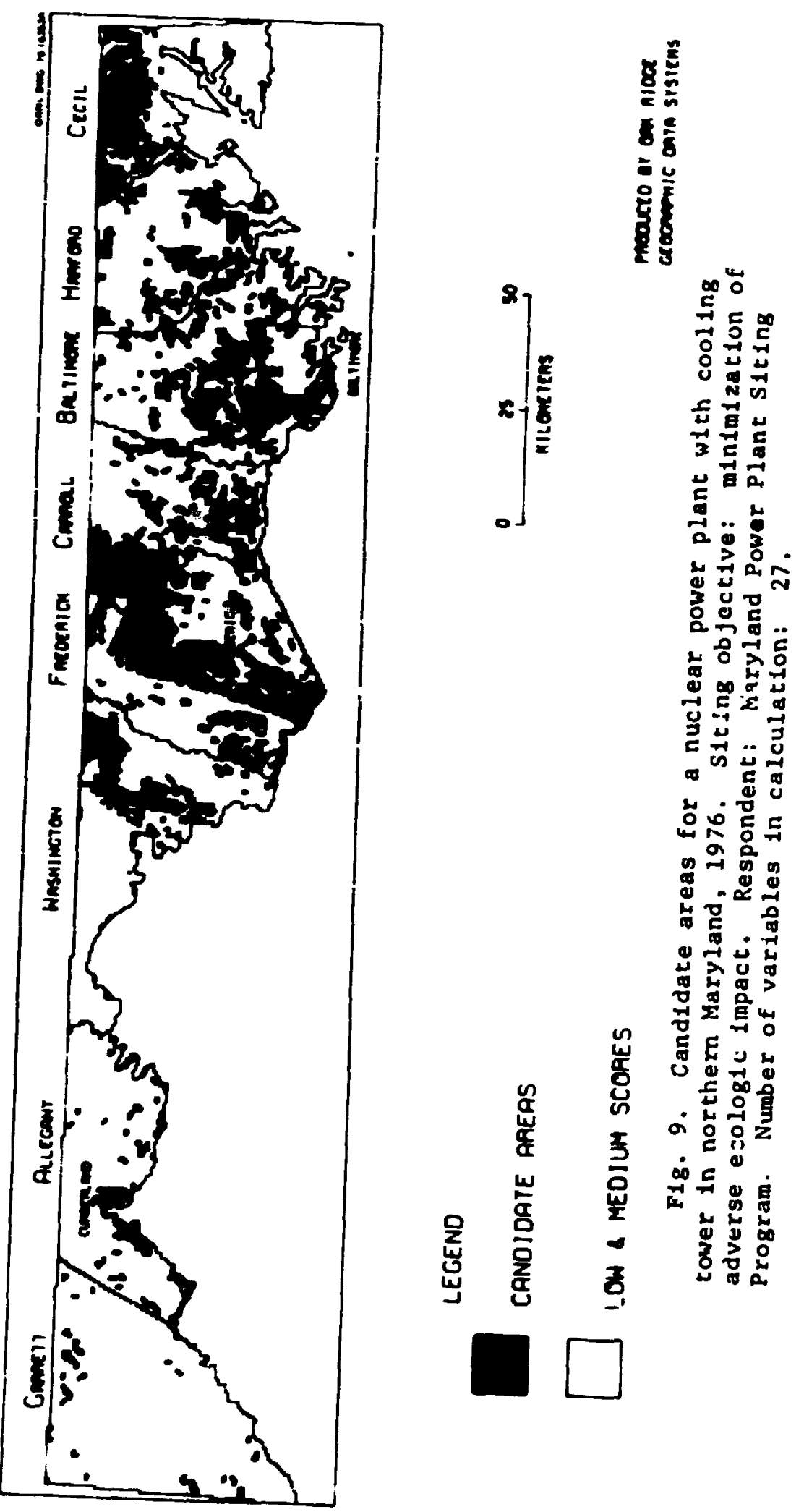


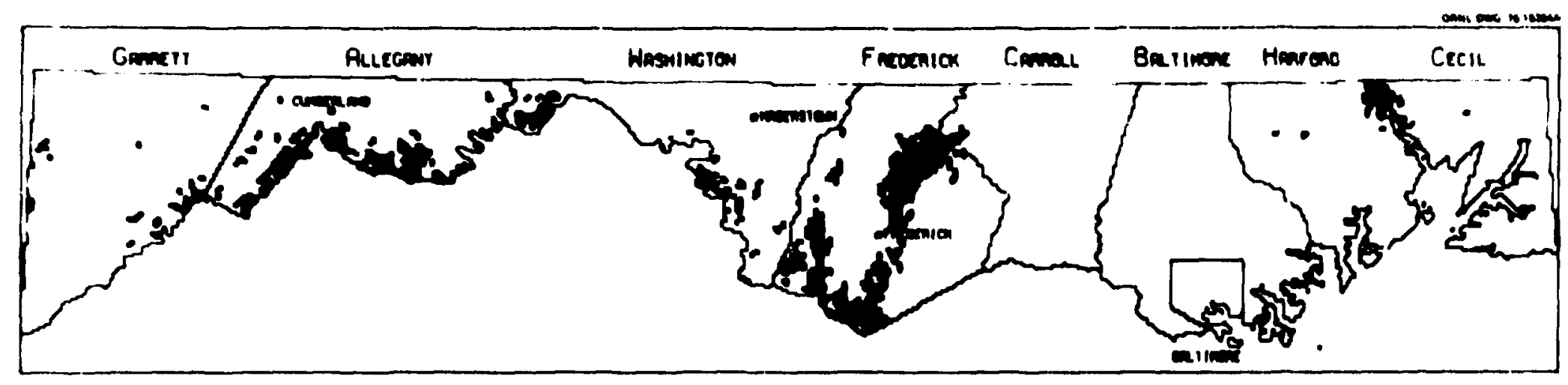

¿EGEND

CANOIDATE AREAS

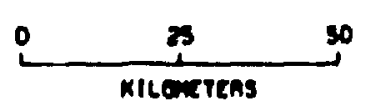

LOW \& MEOIUM SCORES

mouced or an nioce

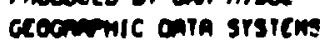

Fig. 10. Candidate areas for a nuclear power plant with cooling tower In northern Maryland, 1976. Siting objective: composite of all objectives. Respondent: Maryland Power Plant Siting Program. Number of varlables in calculation: 27 . 


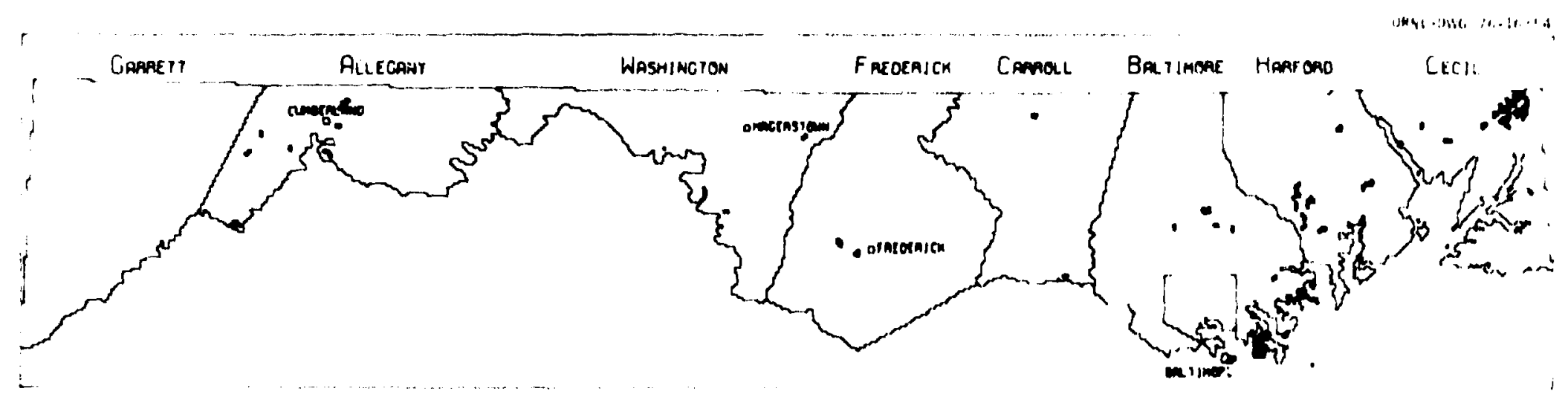

LECEND

CANCIOATE AREAS

$\begin{array}{ccc}0 & 25 & 30 \\ 1 & \text { KILOMETLAS }\end{array}$

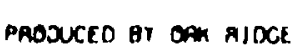

.. I LOW \& MEOIUM SCORES

CEOCAPAHIC DATA STSIEMS

F1g. 11. Candidate areas for a nuclear power plant with cooling tower in northern Maryland, 1976. Siting objective: minimization of adverse ecologic Impact. Respondent: Oak Ridge National Laboratory. Number of variables in calculation: 20 . 


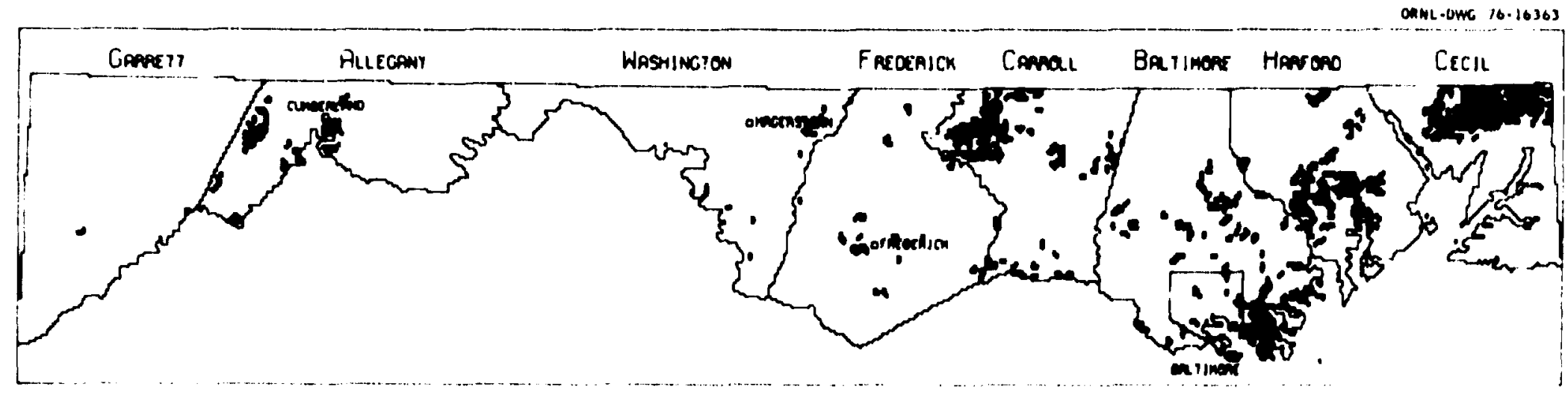

LEGEND

CANOIDATE AREAS

L $\quad 25 \quad 50$

LOW \& MEOIISA SCORES

PAOOUCE O OY OM DCE

CEOCMAPHIC DATA STSIEMS

F18. 12. Candidate areas for a fossil-fired power plant with cooling tower In northern Maryland, 1976. Siting objective: minimizetion of adverse ecologic Impact. Respondent: Oak Ridge National Laboratory. Number of variables in calculation: 20 . 


\subsubsection{Candidate areas for a fossil-fired pouer plant with the object ive of uninizing adverse ecoloric leact: a conparison of coolins syotea options}

The spatial distributions of suitability scores obtained for three different cooling systens for the same objective and from the same respondent are almost precisely identical (Figs. 12-18). This supports the conclusion reached in the discussion of criteria merices that most respondents are unble to distinguish between then without ore precise information regarding streanflor and sois type. It is recomended, therefore, that they should not be treated as separate types of facilities in interpreting the results of this analysis.

\subsubsection{Candidate arias for a nuclear power plant with a conposite sitins obfective: a conarison acong respondents}

Figures 10, 15, and 16 offer a comparison of the candidate areas for a nuclear power plant obtalned from three different respondents. The overall distributions are siaflar though far from identical. The power Plant Siting Progran has fewer candidate-area cells because wre exclustons have been granted in this matrix than in the compatibility indices used fointly for the two nowimai group matrices. For the most part the candidate areas in Fig. 10 are saller concentrations in the same general pattern as those produced by the noninal groups. In the east the difference in size is enough to elfainate nost clusters iarge enough to support a large nuclear facility. A few concentratjuns rengin along the upper Potonac, but wost of the clusters in Washingtion County are ellainated by the Power Plant Siting Progran criteria matix.

The prontnent concentration of high scores along the Monocacy and near Its junction with the Potomac is evident on all three mps, but there are subtle differences in its configuration. Criteria specified by the nondnal groups have brought about tighter clusters with a broader opening for the urban influence of Frederick. A narrow strip of lowerscoring cells occurs on the upper portion of the Honocacy River on aps produced from tnput of the first nominal group and from personnel in the Maryland Power Plant Stting Progras but not on those maps based on Ir.put 


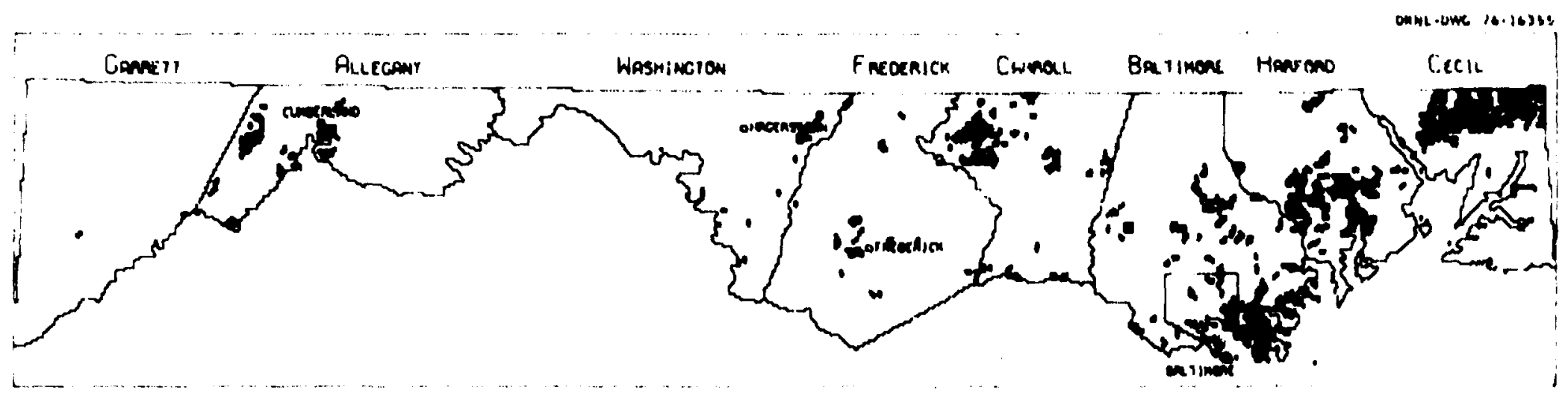

LECEND

$2 \quad 25 \quad$ SILOMETEAS

CANDIDATE AREAS

LOW \& MEDIUM SCORES

PMOOUCEO OT OAN AIOCE

CEOCRPATL DAIA STSTEMS

F1g. 13. Candidate areas for a fosgil-fired power plant with cooling pond In northern Maryland, 1976. Siting objective: minimization of adverse ecologic Impact. Respondent: Oak Ridge National Laboratory. Number of variables in calculation: 20 . 


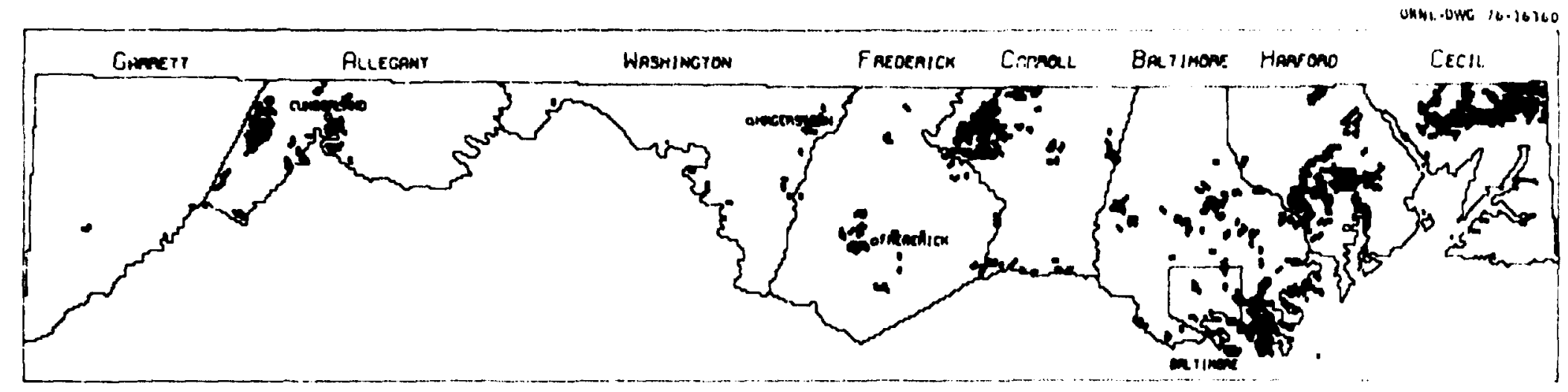

\section{LECENO}

$\left[\frac{25}{\text { KILOMEIERS }}\right.$

CANOIOATE RREAS

LOW \& MEDIUM SCORES

F18. 14. Candidate areas for a fussil-fired power plant with oncethrough cooling technology in northern Maryland, 1976. Siting objective: minimization of adverse ecologic 1mpact. Reapondent: Oak Ridge National Laboratory. Number of vartables in calculation: 20 . 


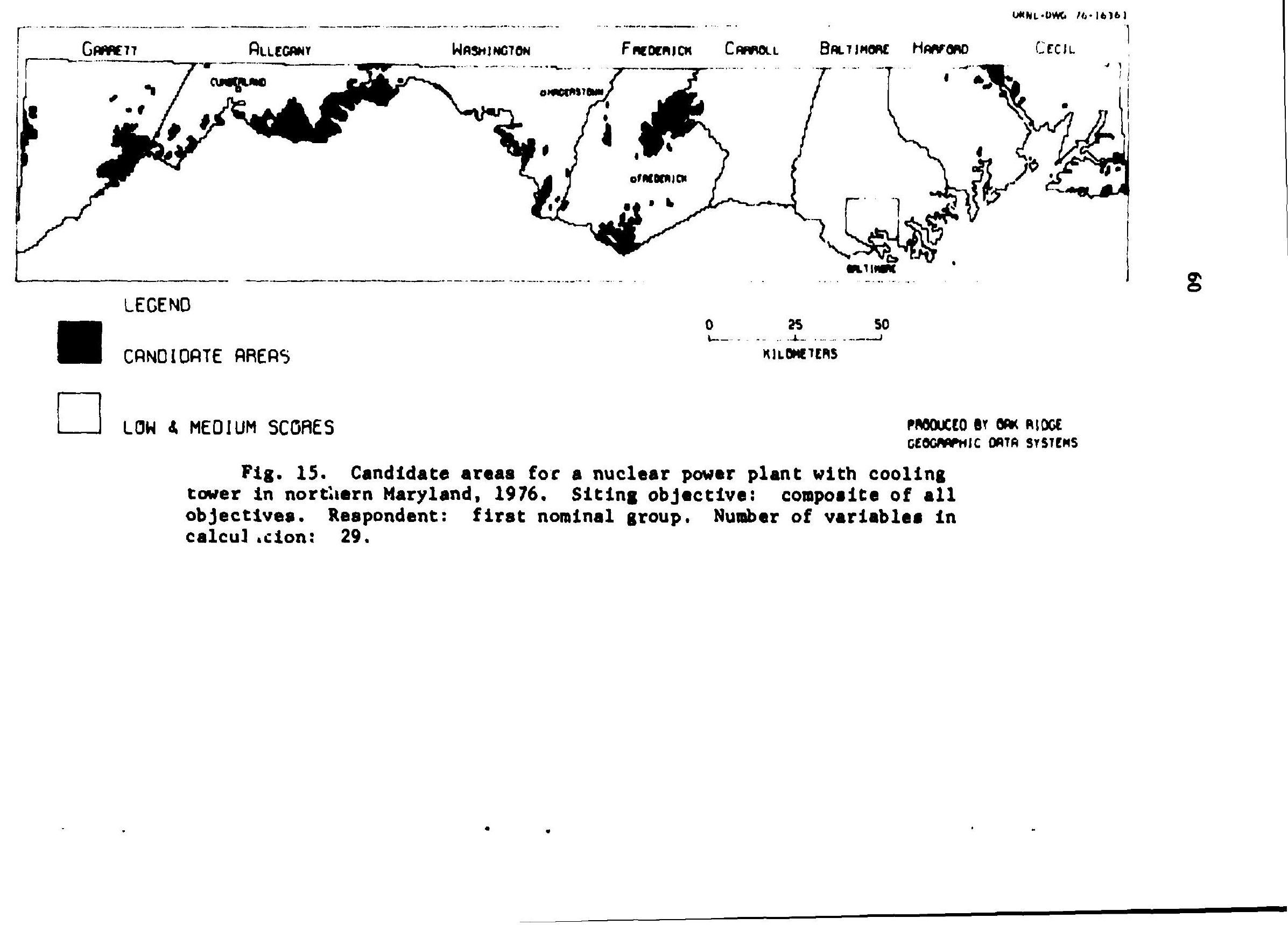




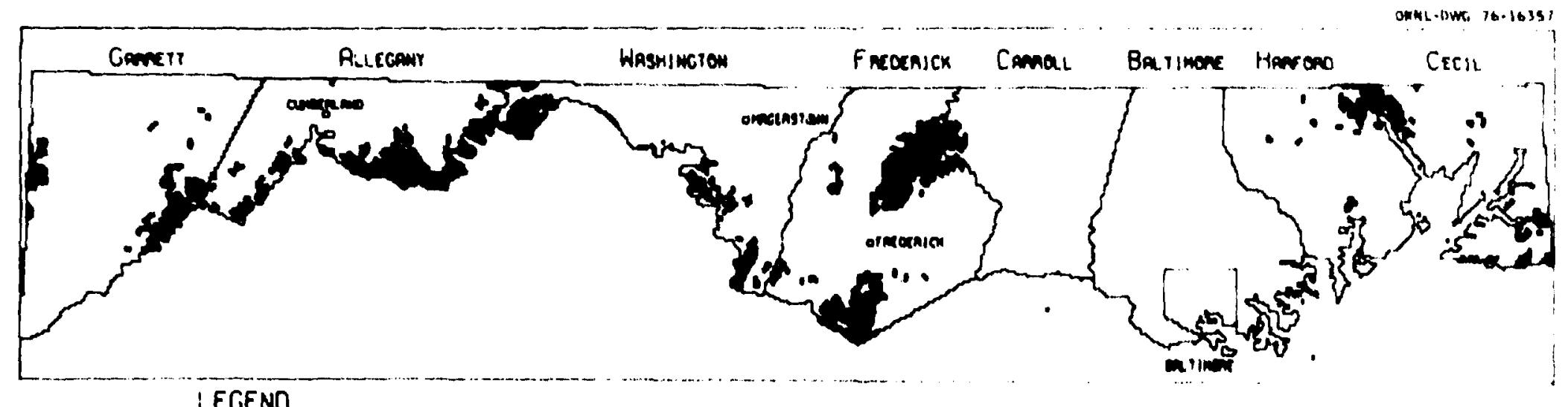

CANDIUATE RREAS

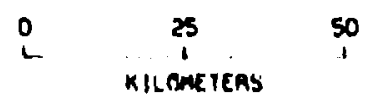

[] LOW \& MEUIUM SCORES

Fig. i6. Candidate areus for a nuclear power plant with cooling tower in northern Maryland, 1976. Siting objective: composite of all cijectives. Reapondent: second nominal group. Number of variablea in calculation: 29 . 


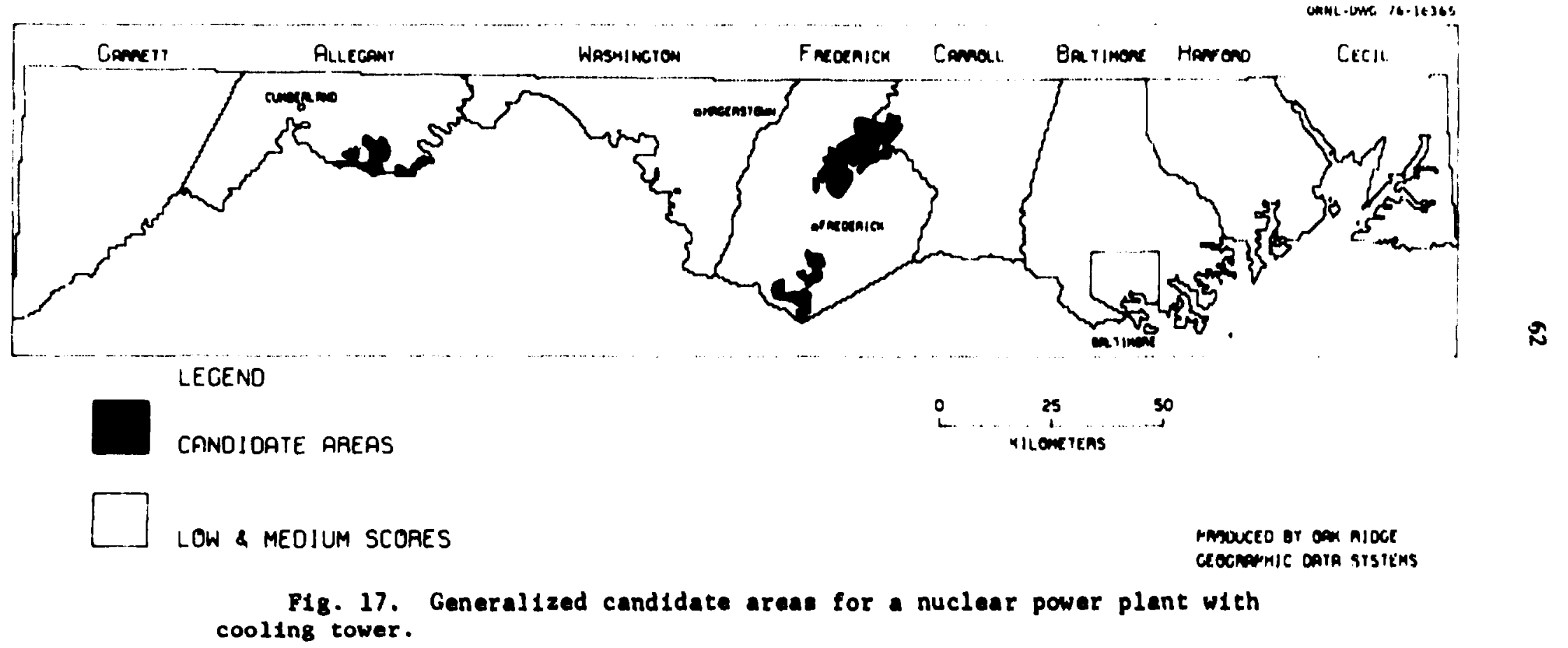



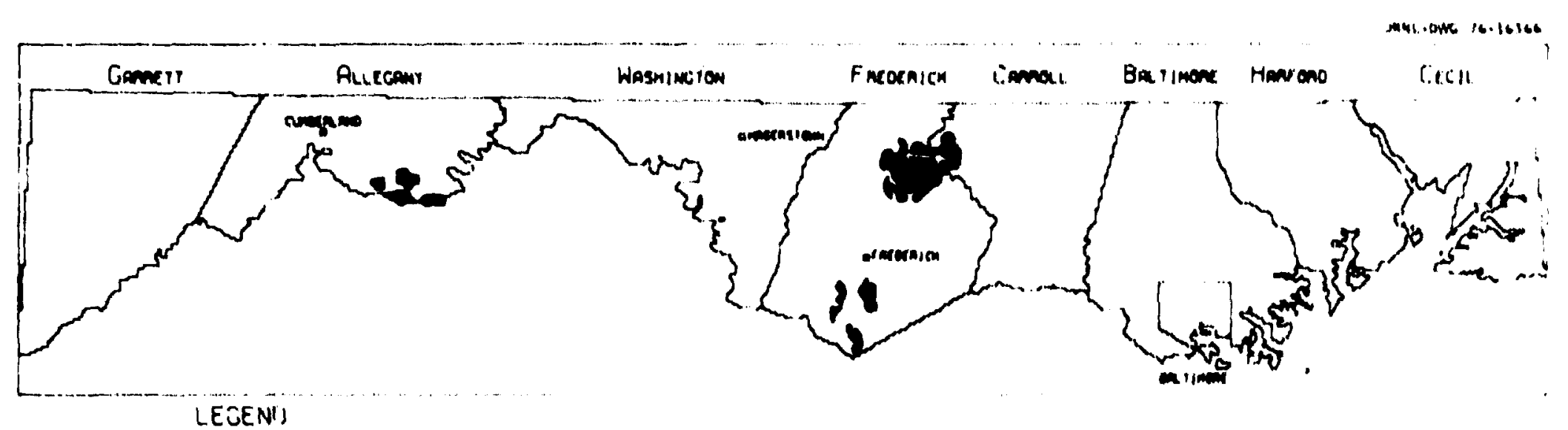

LEGENI

CANDI'IATE RREAS

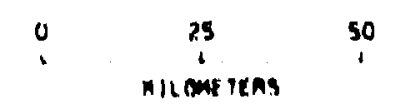

\lceil

L_. LOW \& MEOIUM SCOAES

F18. 18. Generallzed sandidate araas for a fosil-firad power plant with cooling towar. 
from the second nominal group. Apparently this results frov different treatment of the transportation variable.

\subsection{Interpretation of Candidate-Area Maps}

It should be apparent from the aterial presented in this report that a given region has not one set but any sets of candidate areas depending upon the perspectives of the respondents. This accoun is for the difficulty in gaining public and ccrporate acceptaice of most regional-screening packages which operate with a single built-in set of criteria. Yet, regional planners, utility executives, and regulatory officials of ten are faced with the necessity of defining a rigid set of candidate areas from which candidate sites will be chosen. If the LUSP is to be of any use, it must serve as a tool in selecting a final slate of candidate areas representing the hest compromise between all interest groups. The user, therefore, should thoroughly understand the weaning and linitations of the candidate-area maps.

The user should be aware that the waps are not intended as a substitute for the knowledge cr judgment of an experienced siting spectalist. They are simply a meass of examinsng aiternative policies and simulating different viewpoints or priorities in site selection. LUSP is not intended to perform the judgnental decisionj involved in choosing the final set of candidate areas. The judgment of the user is essential to make the decision as to which criteria will doninate the final selection.

Frow a technical standpoint the LUSP prograns allow the user to create a set of compromised suitability scores by treating the previously obtained scores as if they are raw variables. Inportance weights can be assigned to indicate the influence the user wishes a particular set of criteria to have in the final selection. Exclusions can be assigned to low ranges of the scores obtained frow all or a few of the respondents. Frow a theoretical standpoint, however, it is extrenely difficult to represent the power of various interest groups ty a siuple importance weight, and an optimal solution can only be defined as a site in which intich scores dre obtained fros all matrices. 10 of course, very few cells in the entire study region score well on all matrices. 
Perhaps, the best way for the user to employ the candidate-area maps is to exanine and compare then as we have done, looking especially for cells which score highly on numerous extrices. If a concentration of cells appears in almost all candidate-ared waps but scores poorly on one or two maps, the user can decide objectively wnether or not to allow the minority opinion to influence the final selection. If the user decides o:her interests should prevail, at least he will be aware of the potential for opposition, and opponents are assured that their views were considered in the selection process. In soee cases, users my be inclfaed to go against the ajority cpinion, and here again they are forewarned of the potential for strong opposition.

\subsubsection{Candidate areas consistently chosen for a nuclear power plant}

The folluwing exanple illustrates a possible compronise between the candidate-area ms displayed in this report.

Froe a comparison of all candidate areas for a nuclear plant (Figs. $7-11,15$, and 16), 1: can be seen that no clusters of cells large enough to for a candidate sice score highly on all matrices. The ecological matrix assigned at ORML is su stringent that only a few scattered cells have scored highly (Fig. 11), and these are mostly in the eastern portion, which is elininated by the socioeconomic matrix (Fig. 8). If the user has been charged with the respousibility for locating a nuciear plant, he will not be able to disniss all sites so easily. Most likely it will be necessary to set the most stringent matrix aside and examine those whtch allow some pussibility of defining a site.

The remaining maps show that a sizable concentration of cells in the vicinity of the Monocacy River in Frederick County scores hibly on all other matrices. Thus, it is possible to define a large candidate area northeast of Frederick (Pig. 17) with the foreknowitdge that it way require detailed ecologic impact analysis before specifi: sites can be chosen with confiderce. Another large concentration souch of Frederick appears on all maps except those produced by the Power Plant Si:ing Program. This can be defined as a candidate area with an eien gredter warning of the poteritial for ecologic impact. 
Similarly, a few small clusters of cells appear along the Potomac east of Cumberland on all matrices except those emphasizing ecologic concerns. These, too, can be defined as candidate areas with a caveat regarding the need for ecologic impact analysis.

Three generalized candidate areas for a nuclear power plant can be defined as a comprorise between all previously obtained candidate-area map's. If the user feels that more are necessary, he can form a second set of generalized candidate areas which score highly on fewer matrices thar. those shown in Fig. 17. For this set he knows that the chances of opposition are even greater.

\subsubsection{Candidate areas consistently chosen for a fossil-fired power plant}

A comparison of all candidate-area maps for a fossil-fired power plant with cooling tower (Figs. 3-6 and 12) reveals that ro clusters of cells score highly on all matrices. The distributions obtained from the socioeconomic and ecologic matrices completed by the Power Pl int siting Program are almost precisely the inverse of each other, and this precludes the possibility of cells scoring uniformly high on all maps. Most of the upper-Monocacy candidate area and portions of the lowerMonocacy candidate area appear on four of the five maps (Fig. 18). Of the cells included in the generalized candidate area, half must be accompanied with reservations regarding socioeconomic impacts and half with ecolog:c reservations. A few ssattered cells near Cumberland a: : appear en four of the five candidate-area maps, and these bear similat reservations of notential impacts.

\subsubsection{Reliability of candidate-area maps}

In interpreting candidate-area naps, the user should remember that they represent only those variables included in the data base and the criteria assigned by the respondent. In any case, when the user has firsthand kncwledge of contradictory information or of extenuating circumstances, :hat knowledge necessarily must be perritted to overrule the results $c f$ the screening procedure. In adaiticn, reliability of the candidate-area ilaps is affected by the accuracy of the data, the 
respondents' understanding of the data, the completeness with whith siting factors are covered, and the sensitivity of the screening algorithm to the number of variables included in each calculation.

\subsubsection{Accuracy of the Maryland Data Base. The accuracy of all} variables obtained from the Maryland Automated Geographic Information System (MAGI) was checked against independent sources wherever possible. If other sources were not available, the data were checked foz internal consistency between categories of different variables containing approximately the sane information. For example, cross tabulations were nade between the forest type variable and the forest cover category of the land use and land cover variable. In other cases, sinple visual checks of the mapped variables were sufficient, as with the county number variable, wore errors are easily detected as noncontiguous cells.

The data appear to be extremely accurate, especially when the size and areal extent of the base file are taken into account. The discrepancies between MAGI and other sources were less than $1 \%$ on several variables and did not exceed $6 \%$ or any of the variables so checked. Cross tabulations within the MAGI variables indicate enough congruen:e of similar categories to suggest that the accuracy and precision of the geocoded daca are well within acceptable bounds.

A more significant problem with the MAGI variables results from incomplete documentation of the codes used in storing the data. A total of 22 codes appear in the data files but not in the accompanying documentation (Table 11). Some of these, ro doubt, resuit from typographical

Table 11. Undocumented or trroneous codes in the Marvland Automated Geographic Information System

\begin{tabular}{lcc}
\hline Variable & $\begin{array}{c}\text { Number of undocumented } \\
\text { or erroneoss codes }\end{array}$ & $\begin{array}{c}\text { Number of cells } \\
\text { affected }\end{array}$ \\
\hline Surface vater quality & 1 & 1 \\
Transportation and transmission & 8 & 13 \\
State 3nd Federal lands & 1 & 1 \\
Mineral resources & 2 & 56 \\
Foresi 'ype & 6 & 61 \\
Soil group & 3 & 39 \\
Land surface slope & 1 & $\frac{2025^{*}}{2196}$ \\
\hline$\quad$ Total & 22 & 2196 \\
\hline
\end{tabular}

an MAGl this variable is named "Topography." The urcocumented code is zero (0), which apparently represents water surfaces. 
errors in digitizing, while some are accurate codes for which no key has been provided. It this were the only problen with the docunitation, the degree of error still would be acceptable, for these affect a maxinum of 72 of all cells. Since the meaning of the undocumented "land surface slope" code can be deduced by exanining the mapped variable, no nore than 171 cells $(0.57)$ remain truly undocumented.

A wuch larzer nuber of cells have insufficient doc wentation. It is of ten difficult to understand precisely what is meant iy the variable and category descriptions. For exaple, the geologic formition variable contains a description of overburden thickness, but the terns "thin," "nedium," and "thick" are never defined numerically. often categories are combined aukwardly, as in the case of water and sewer factlities, where two independent variables are coded as a single variable. Some variables contain categories which are not mutually exclusive. For instance, transportation and transaission facilities are cosbined, and there is no indication as to which facilities are involved when they occur in the same cell.

The ef fect of insufficient, confusing, or aisleading documentation is difficult to assess because it varies from one respondent to another. Through prolonged contact with the syster an individual may eventually understand the meaning of all but a few codes; however, it is sometimes necessary to obtain expert opinion from specialists, sho can hardly be expected to spend weeks or wonths learning the data base. Herse, understanding of the data varies from respondent to respondent and occasionally may influence the spatial distribution of candidate areas.

\subsubsection{Missing factors. As a test of the completeness of data coverage} in the Maryland Data Base, both nowinal groups were asked to name regional and local siting factors without reference to the 1 ist of variablee already available. Their lists of factors were then compared with the 11st of variables in the da:a file. Roughly equivalent information was found to be avaliable for most of the factors named. Moreover, all of the missing factors were those which raniked relatively low among the siting factors. In descending order of importance the missing factors as defined by the first nominal group are (1) the existence of regional and local planning agencies to manage anticipated social and economic 
chanjes, (2) the local perception of plant desirability, (3) the avallability of water and land in terms of ownershio, (4) meteorological hazards, (5) background radiation, and (6) visual crmpatibility. The second noninal group added proxinity to load denand - i factor wich probably should be handled at a broader scale of analysis.

A comarison of the two lists also underscores the need for develupment of factor indices rather than simple measured variables. A case in point is the transportation accessibility factor naned by the two noninal groups. It is intended to measure the relative ease of transpozting workers dud aterials to and from urban areas. Yet, the data base contains only a listing of the transportation facilities available within each cell. Unless the raw variable is entered into an accessibility wodel along with road and rail distance to nearest distribution centers and labor sources, it is at best an expedient surrogate for the Information requested by the nominal groups. The calculation of proximities to rodds and railroads is a simple first step toward the type of factor models needed for adapting the data file to serve site screening purposes fully.

Each factor model in itself would require extensive analysis and considerable research time. Priority was given to those factors wich rank highly on wost matrices, with the greatest effort devoted to estinating the availability of sufficient water for cooling. ${ }^{15}$ Considerable ef fort also was expended in adapting and applying existing population wodels to the data base. Additional work needs to be done on these and other vartables.

\subsubsection{Sensitivity of the screening algorithm}

The number of variables included in each suitability calculation is a water of concern in interpreting the candidate-area maps. It wust be ascertained that the coverage is sufficient to produce patterns wore discriminating, for example, than a siople replization of the stream courses. On the other hand, the incremental cost of adding new variableg to the data base is a considerable expense in tiwe and woney which wust be balanced against the potential influence of the "ariable on the suitability scores. The sensitivity of the screening aigorithe (the degree to which the final scores are altered by changes in one or wore 
variables) is a major consideration in justifying the collection of additional variables of low importance.

To test the influence of variables at each level of importance, suitability scores were calculated and candidate-area maps were produced frow each matrix, first including all variables and then successively deleting the least important ones. The results obtained frow the first nominal group's composite atrix for a nuclear power plant are offered as an example of the sensitivity analysis. All variables in the criteria matrix were grouped according to their importance weights. The first calculation (Fig. 15) included all vartables, the next deleted those with an importance weight of 1 , and so on until only those with an importance weight of 10 remained. The score distributions were then comared statistically and spatially to deternine at which points significant changes occurred.

Coefficients of correiation ( $r$ values) were computed between the scores obtained fron all 29 variables and those obtained at each step in the deletion, and the $r$ values were graphed (Fig. 19). It can be seen that the scores are only slightly affected by removal of the least inportant variables (represented by an inportance weight of 2 , since no variables vere assigned weights of 1 ). In fact, the $r$ value is still extremely high when all variables weighted 2 through 5 are dropped, indicating that this particular calculation is not very sensitive to variables of low importance. However, a marked break in the curve suggests that the distribution of cell scores changes significantly when variables with a weight of 6 are deleted. Theieafter, the correlation decreases consistently.

An examination of the suitability maps reveals iftle change in the overall pattern of candidate areas between those obtained from the full watrix and those with variables of low importance deleted. Again the first significa:t alteration appears when importance weight 6 is dropped, and variables of higher weigrits exhibit a considerable influence on the spatial distribution.

It is apparent fron a comparison of Fig3. 15 and 20 that the same concentrations of high-scoring cells would have been obtalined with or wh thout the nine variables of lowest importance. Their ticlusion in this matrix, therefore, is somewhat superflusus, and they neither help 


$$
\text { Lis }
$$




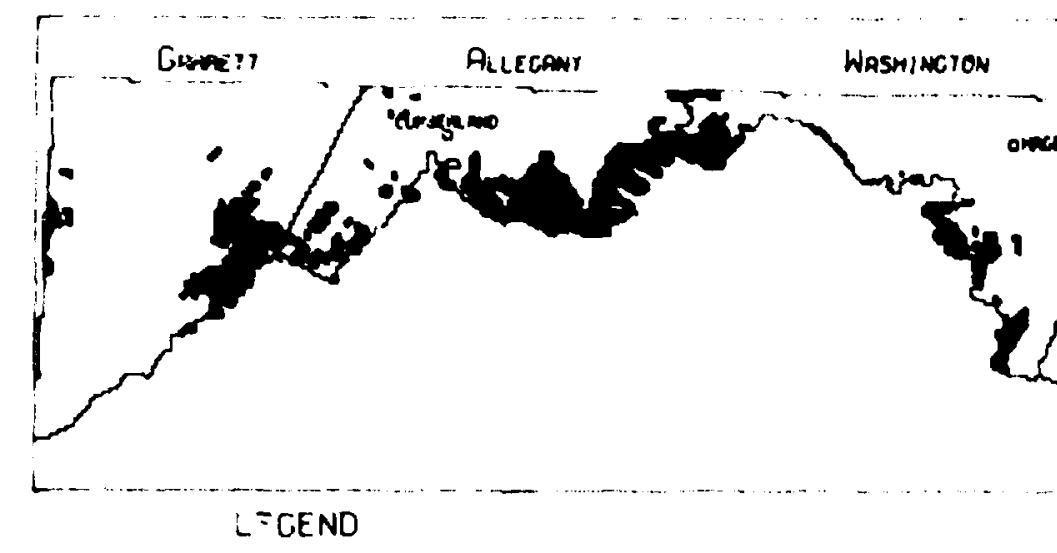

CANDIDATE AREAS

LOW \& MEDIIJM SCORES

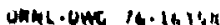


nor hinder the accuracy of the candidate-area maps. Thus it can be anticipated that the cost of obtaining the assing variables identified by the nominal groups will not be justified for those with inportance weights of 5 or less.

At the opposite extreme, when only proxinity to water, seisaicity, and proxinity to endangered species are included, the distribution is sinflar to the strean pattern (Fig. 21). Population density has been considered ta $\mathrm{Fig}_{8}$. 22. and the resulting pattern is one which could have been reached intuitively without the aid of screening algorithms and extensive data bases. Only when variables of inportance veight 7 or greater are included (Pig. 23) do we begin to see the energence of candidate areas which have been identified consistently by other iEspiadents. The calculations seen to become nore and nore discrininating as wre variables are added through importance weight 6 (Fig. 20).

It can be concluded that the reliability of this particular criteria matrix is greatest when 20 or nore variables are included. However, the nuber will vary for other matrices obtained fros different respondents or for different facilities and siting objectives. In practice it would be sdvisable to perforn this type of sensitivity analysis for each atrix and to collect additional data for all assing factors ranking within the sportance ranges found to affect final scores.

\subsubsection{This defintition of candidate areas}

The decision as to which scores will be Included in the candidatearea definition 18 an artitrary one. As discussed in Sect. 2.2.4, in this analysts all cells with scores one or wre standard deviacions above the mean have been considered as potential candidate-area cells. Ii the wer 18 willing to accept lower scores or is forced to do so because of an insuficient nuber of potential sites at the higher level, he way alter the definition to suit his needs.

P1gures 24 and 25 illustrate the effect of successively lowering the definition. In this case the candidate areas have broadened to offer ore choices for site selectivn, but the general pattem has not changed greatly. This result is obtained because the excluded areas are still excluded regardless of wich positive scores are included. The effect on eiting is that lece optial sites any be chosen, but the really crittcal areas are still avolded. 


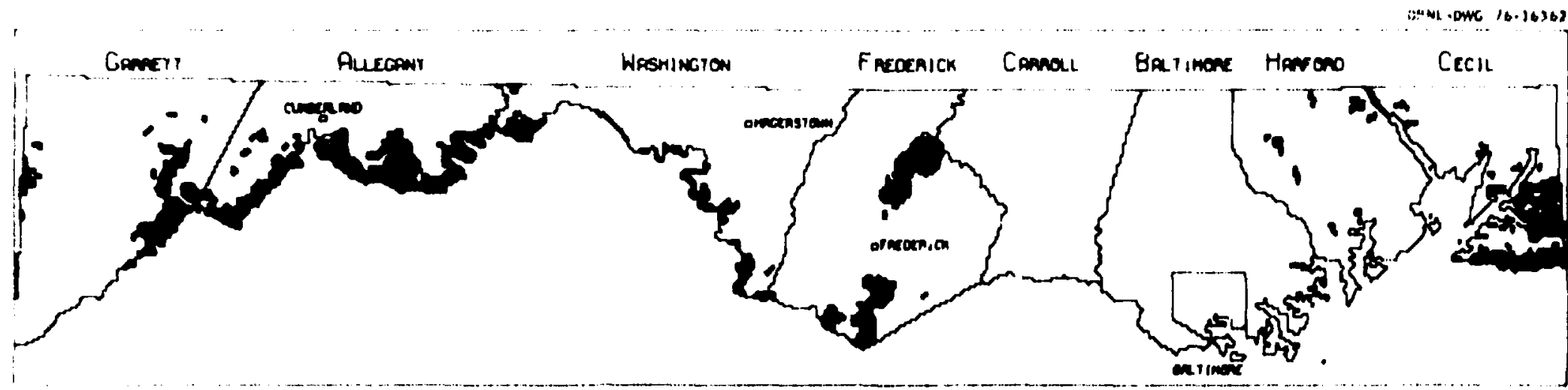

LECEND

CANDIDATE GREAS

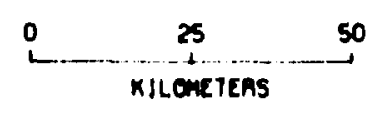

LOW \& MEDIUM SCORES

PMCOUCEO OY AN AOCE

GeOCNPMIC Data STSTEAs

F18. 21. Candidate areas for a nuclear power plant with cooling tower In northern Maryland, 1976. Sit1ng objective: composite of all objectives. Respondent: f1rst numinal group. Number of variables in calculation: 13 . 

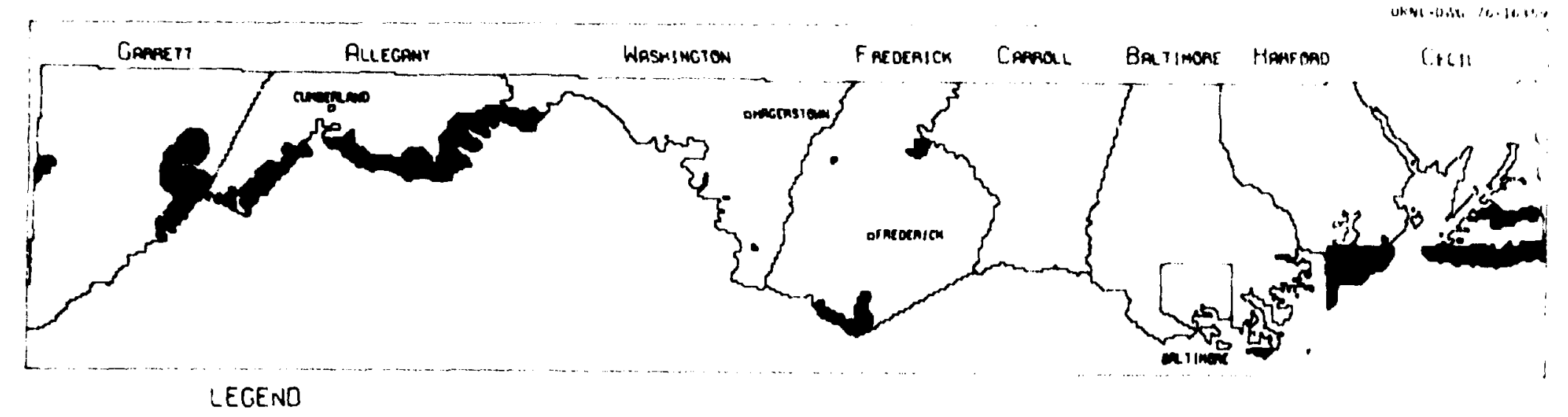

C.ANDIOATE RREAS

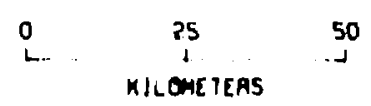

$[\cdots]$ LIW \& MEOIUM SCORES

PAODUCEO BY OAN AIOCE CEOCAPPMIC DATA STSTIIHS

F18. 22. Candidate areas for a nuclear power plant with cooling tower In northern Maryland, 1976. Siting objective: composite of all objectives. Respondent: first nominal group. Number of variables in calculation: 5 . 

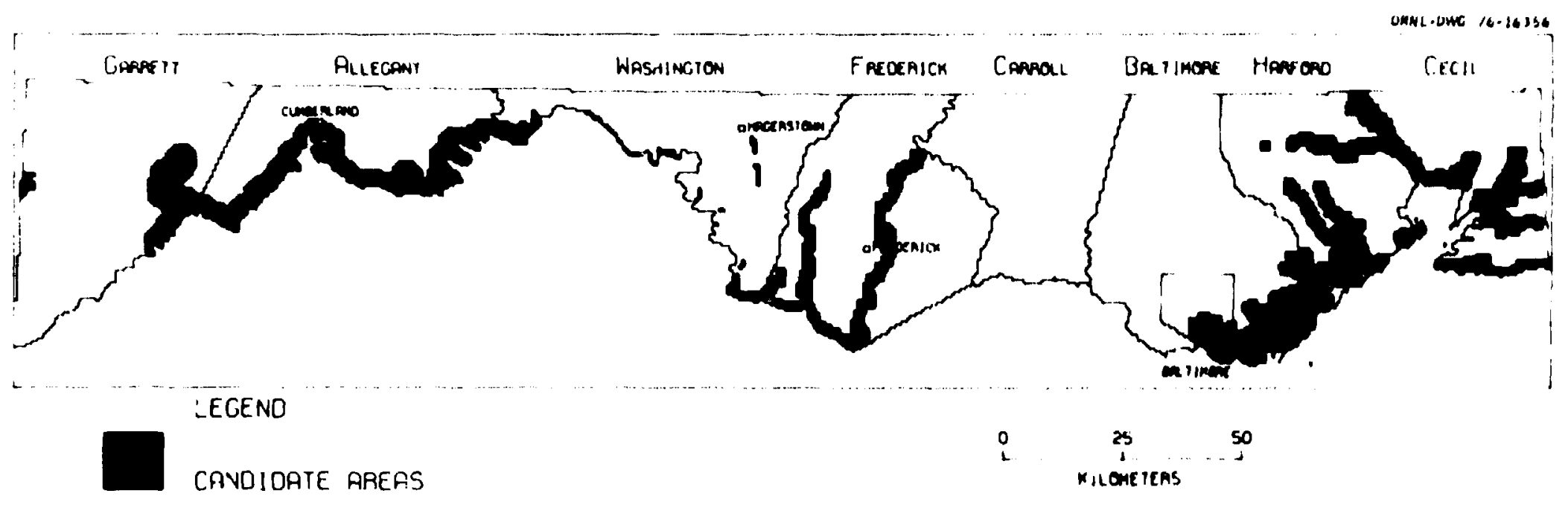

[ LOW \& MEDIUM SCORES

PROOUCEO QT $\operatorname{con}$ AIOCE CFOCAPHIC CAIA SISIEMS

Fig, 23. Candidate areas for a nuclear power plant with cooling tower in northern Maryland, 1976. Siting objective: composite of all objectives. Respondent: flrst nominal group. Number of variables in calculation: 4 . 


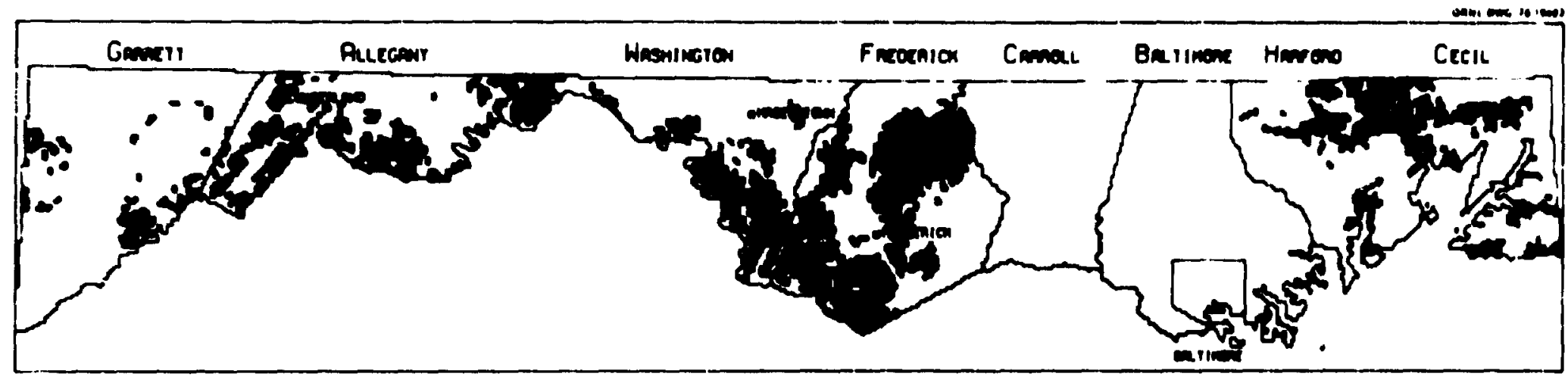

LEGENO

CANDIOATE AREAS

LOW \& MEOIUM SCORES

F1g. 24. Candidate areas for a nuclear power plant with cooling tower In northern Maryland, 1976. Sicing objective: composite of all objectives. Respondent: Maryland Power Plant Siting Program. Number of varlables in calculation: 27. Candidate areas are mean score or above.
Pmoducto or on Alore Georavernic onta srstens 


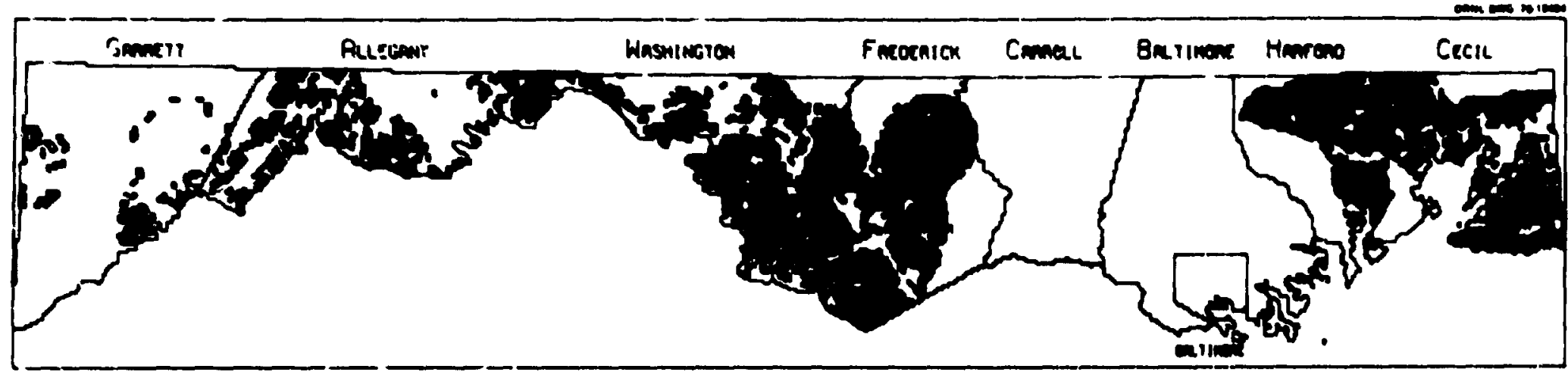

LEGEND

CANOIDATE AREAS

0

23 -30

nutorenens

LOW \& MEDIUM SCORES

meoceto or on nioce erecommic onith sisiens

Fig. 25. Candidate areas for a nuclear power plant with cocling tower in northern Maryland, 1976. Siting objective: composite of all objectives. Respondent: Maryland Power Plant Siting Program. Number of vartables in calculation: 27. Candidate areas are one standard deviation below mean score or above. 


\section{RESEARCH ACCOMPLISHENTS}

5.1 Appitcation and Analysis of the ORNL LUSP

A najor accomplishaent of the iiPPSP is that every land parcel in northern Maryland has been evaluated in regard to its suitability fur power plant siting. Numerous sets of criteria representing the views of different siting specialist.s for variaus siting objectives have been applied to the Maryland Data Bas: and candidate areas have been identified according to each. ORNL does not have the responsibility of choosing a final slate of candidate areas, but it can be noted that concentrations of high-scoring cells in the vicinity of the Monocacy River northeast and south of Frederick and on the Potomac River east of Cumberland appear on almost all candidate-area maps for fossil-tired and nuclear power plants. Caveats regarding ecologic impact have been noted for all generalized candidate areas.

The significance of this exercise is that automated regiona] screening techniques have been taken beyond mere developmert to the stages of application and analysis. Criteria matrices can vary substantially among restondents, and the differences are reflected in the spatial distrbutions of high-scoring cells. Furthermore, most respordents are able to distinguish between factlities based on fuel types but not on cooling systems. The distributions of candidate areas for nuclear power plants are scmewhat. different from those for fossil-fired plants fo: a composite siting objective and dramatically different for an ecoiogic objective.

In order to accomplish the regional screening and to implement the analysis, three programs for thamaic mapping, proximity calculation, and computation of cell suitability scores were developed and documented. 7

\subsection{Criceria Definition}

The criteria matrices constitute a contribution to power plant siting methodulogy. Some were obtained under highly structured group techntques, 12 and other, were determined administratively just as criteria are defined in mosc utility-siting applications. The criteria 
atrices illustrate emphatically that there is no "right" set of cricerfa or "best" candidate area. "Expert" opi ion is as diverse as the individuals involved, and the resultant cansidate areas should be vieued as spatial expressions of those opinions. Thus, the validity of any screening procedure, automated or mani, which utilizes a single, rigid set of criteria defined by "experts" can be questioned.

\subsection{Expansion of the Mary land Data Base}

An attempt was made $t ?$ incorporate into the data base all of the important factors which were identified in the criteria definition phase. In the course of the project the Maryland Data Base was expanded f ron the 27 MAGI variables to $\mathbf{5 2}$ variables. Most of these were obtained by adapting available digital information, such as U.S. Census Tapes and USGS Water Tapes, to a format and spatial resolution compatible with MAGI.

Special attention was given to the modeling of water avallability. 16 The result is a compute: package which enables the user (1) to delimit any region of the United States by state, county, drainage area, or latitude-longitude frame; (2) to recall daily flow values from the USGS Water Tapes for all gaging stations within the study region; (3) to compute estimates of the recurrence frequency of low flows; and (4) to calculate the reservoir drawdown capacity which would be necessary to maintain a given rate of flow at any specified rate of consumptive use.

Population density and two weighted population density values (5-nile and 30-mile site population factors) were calculated for all c:.11s in the study area. Emphasis was placed on developing factors afplicable to site screening at the regional and local scales of arialysis, and the resulting values were entered into the Maryland Data Base.

The analysis of air diffusion, a factor which wust be considered in sitinz fussil-fired power plants, was performed as an example of the types of analyses which must follow regional screening to select specific condidate sites frow candidate areas. 4 To alternative models of alr diffusion frow a point source have been applied to two candidate 
sites in Washington and Frederick Counties, and a measure of population density has been added to evaluate air pollution impacts on populated areas. Since the infornation has been generated for only two points, it cannot serve as an air diffusion index in the Maryland Data Base. 


\section{CONCLUSIONS, RECOMERDED APPLICATIONS, AND RESEARCH NEEDS}

The primary purpose of this report is to explore the usefulness and fuactional requirenents of cell-based land use screening procedures. Hence, the conclusions will emphasize the utility of the ORUL LUSP, its advantages and disadvantages in regional and local sicing analyses, and recomendations for future applications and research.

The results of the MPPSP suggest the following conclusions:

1. The ORNL LUSP is a useful tool for regional screening of geographic information systems even when the systens are not designed for: the specific problem of power plant siting.

2. The ORIL LUSP can serve as a means of simulating alternative siting policies in order to anticipate potential conflicts before they become atters of public concern.

3. Since the construction of a geographic information systen is the greatest potential constraint to the developnent of an automated screening procedure, the data base should be designed to serve diverse uses. The shared cost can be minimized by considering the needs of potential users during system developwent and by including only those variables which recefve high importance weights on numerous iriteria matrices.

4. Siting factors must be viewed in the context of a spatial hierarchy of physical, economic, and social phenomena. Each factor should be examined at the approprfate level of spatial resolution and stored in a multiscale data base.

5. The greatest iimitation to the interpretation of the candidate-area maps in this study is that most siting factors are represented by $x a w$ variables rather than by Indices derived fron factor models.

These findings are discussed in greater detall in the following sections. 


\subsection{Recomended Application:s}

The ORUL-LUSP places a quanticative screening algorithe properly within a comprehensive site selection process. Host published reports on automated screening techniques imply that a definftive selection of candidate areas can be ade by the computer and that a single set of criterta is sufficient for regional screening. ${ }^{8.9}$ In contrast, our work leads us to recognize that an automated screening procedure is one tool among many which ay be useful in candidate-area selection. Furthernore, many sets of candidate areas can be identified depending upon the values of differeat interest groups, and the ORVL-LUSP can be used for identifying and resolving potential conf, ts.

The ORn-LUSP is designed as a tool for simulaing the effects of alternative siting policies. It is particularly useful early in the selection process when the study area is being screened to identify candidate areas capable of hosting a generating facility. The early application of the screening procedure can help incorporate the views of diverse groups while it is still possible to acconndate those views. The users can create ariteria matrices which anticipate the requirements of other interest groups, or they can ask ropresentatives of known interest groups to create their on motrices. For exaple, the views of a recognized conservation society wight be entered into a suitability calculation for the objective of mintaing adverse ecologic ipact. The power of the ORnL-LUSP is that it is designed to identify and weight site selection criteria for a hierarchy of geographic scales - national, regional, and local.

This report has been written as if the users are utility-siting specialists or regional planners, but the features of the URR-LUSP also make ft well suited for use by regulatory agencies in evaluating alternative sites. In fact, a strict incerpretation of the NEPA requirenents for consideration of alternative sites could demand regional screening to deteraine the most feasible site with the least adverse iupact. Even under present regulatory practice a regional screening procedure could aid in alcrting regulatory officials to potential conflicts before they become issues of public concern. The Nuclear Regulatory Comission and 
any state agencies with responsibllities varying froe evaluation to predesignation of energy facility sites aight becefit from such an approach. The ORNL LUSP is particularly well suived to agencies like the Tennessee Valley Authority and the Maryland Power Plant Sicing Progran which are charged with che responsibility of selecting facilfty sites and simultaneously protecting public interests.

A third posstble use for the ORNL LUSP is in wodeling future scenartos of energy supply. Most projections of energy production have been at the national scale and have not been concerned with the spatial distribution of production facilities. Hovever, there is some impetus to create projections with a higher degree of spatial resolution. T.ue Water Pesources Council, for exasple, is attempting to project water requirceents for energy production to the year 2000 for miticounty units called aggregated subareas (ASAs).

While energy production for multistate regions may be deterwined by econonic considerations of supply and denand, the actuai placenent of facilities at a county level of resolution will be deternined by the bility of the areas to support the facility physically and econonically and to bear its social, econonic, and ecologic inpacts. A regional screening procedure could be used to build spatial scenarios of energy production just as econonic nodels have been used to project aggregate supplies. Furthermore, it should be recognized that the aggregate supply ay ultinately be constrained by the availability of a sufficient nuber of feasible sites, and the spatial scenarios should serve as checks against aggregate supply scenarios. It nay be possible, for exaple, to detenine approxieately how wch additional electrical generating capacity can be sited before it is necessary to resort to location unacceptable in regard to ecologic impact or econonic feasibility.

\subsection{Punctional Requirenente for Puture Applications}

\subsubsection{The reorraphic inforntion syster}

The developant of a geographic inforwation aysted is a afor consideration in estavlfahing an automted screening procedure like the 
ORI LUSP. The cost, which varies according to the nuber and types of daca itens, is excessive for wost single applications. The greatest portion of the expense is for conputer harduare and sof tuare to handle the storage and retrieval of data and for the capture of key data itens - a one-tive expense which could serve eany applications equally well. Whenever possible, it is advisable to develop a single inf smation systea for a region ind to incorporate general capabiities for access by numerous users. It is unlikely that the faitial data coverage will be sufficient for power plant siting or wst other specific applicatzons, but during syste devilopment an attempt should be made to identify potential users and consider their needs.

Whether the user is establishing an infornation systed dedicated to a single application or is adding supplemental data itens to a preexisting zysten, siting criteria should be defined early enough to serve as guides ir. deternining data requirements. Too of ten, jata collection is preceded by Insuffictent forethought and analysis. Most geographic information systems constructed in such an a priori maner contain numerous variables which are expensive to obtain and yet are relevant only to a few specific applications. On the other hand, a clear definition of siting criteria, including the importance of each variable and Indicating criticel categories, can lead to efficient collection of useful information in the proper for fur the intended application.

The operation of the MPPSP suggests that the Noninal Group Process is a fast, conventent weans of obtaining siting criteria. It could be eapectally helpful in incorporating expert opinion on the necessary data Iteas to be included in a system under development. In fact, the MG? and sinilar task group techniques work best when the participants are not constrained by a rigid list of the variables already avallable.

\subsubsection{The aultiscale approach}

A second major consideration is the development of a conceptual framework for dealing with the numerous factors affecting site suftability. The experience in this and other studies at ORI 18 that these factors must be viewed in a spatial context and exantned at the scale of analyois appropriate to each. In a geographic infornation sgten the 
scale is deterained by the cell size employed in capturing and storing data, and care aust be taken to assure that the cell size does aot greatly exceed the spatial resolution of each data fiten. Of ten it is ippractical to establish a sall-cell data base for the entire region, as has been done in the :PPSP study area. A wre efficient approach is to build a witiscale data base and to screen for suitability according to the donfinat factors at each scale. In going fron the national to the local scale it is necessary to establish complete data coverage only In those areas which survive each successive screening-

For each factor there is a "natural" scale of operation which depends upon its functional interaction with ocher factors and its potential for interaction with the proposed facility. Indeed, sone factors operate at wre than one level. Transportation accessibility, for exaple, should be treated at the local scale to deternine hou much construction will be requited to ilnt the cell with a local transportation network and at the regional scale to evaluate the iatercoriectivity between the local network and sources of labor, construction materials, or fuels.

\section{7,3 Suggested Puture Research}

The nost pressing need for future research is in the development of regionsl and local siting factor models. Nunerous models have been developed for use with a know spectific site, but the wre difficult problea of dealing with thousands of potential sites has received far too little attention in siting wethodology. Air quality inpect and transportation accessibility are factors which deserve special attention in future research. In fact, it would be desirable for each of the najor siting factors identified by the noninal groups to serve as the focus of a sophistcated wodeling effort at the regional or local scale.

$A$ second water of concern 13 the role of citizen input in regional or local screesing. The use of various sets of siting criceria defined by groups of experts and representatives of utilities and special interest groups 18 not intended to preclude consideration of the opinions of other citizens who will be affected by the siting decision. Indeed, the intent is to anticipate genuinely adverse impacts on local popula- 
tion before the final decision is ade. It is unlikely, however, that the screening procedure can detect opposition wich results from local perceptions of, for exaple, the desirability of econonic growth in general or the safety of a particular plant. The issues which deternine such local perceptions are too complex to be exanined at the regional scale. Even at the lccal scale it would be extresely difficult to consider this factor for every cell. A prolininary hypothesis would be that the proper stage for consideration is durtag the selection of canditace sites fro candidate areas, since the candidate areas are large enough to contain several small towns or conmaities. This question requites additional research. 
REFERENCES

1. R. H. Platt, Interiace of Low and Jeagraphy, Pesource Paper Wo. 75-1, Anerivan Assoctation of Geografhers, Weshington, D.C., 1976, P. 6.

2. I. D. Calvert, Jr., U. L. Heilon, and H. L. Suith, Nuilear Power Piont Siting: A Generalized Prxess, Atonic Industrial Form, Inc., New York, 1974, p. 9.

3. I. L. Kellars, Design with Kature, Matural History Press, Nev York, 1969.

4. G. T. M11ler, Jr., Living in the Envimoment, Comepts, Problems, and Alternatives, Uadsworth Pulishing Comany, Inc., Belmont, California, 1975, pp. 196-197.

5. Maryland Departhent of Stace Planing, Marsizand Autanated Feojrohi: Iiformation System, Technical Series, Pub. Wo. 207, Baltivore, 1974.

6. S. L. Yaffee and C. A. MIler, Toward a Regicnal Power Plant Sitinj Method: AEC-Maryland Rejional Sitiny Factors Stind, FY 1974

Progress Report, Oau/mi-4944 (1974).

7. J. S. Jalbert and J. E. Dnbson, A Cell-Based Land Ise Screening Procedure for Regional siving Amalysis, oRu/LURSG/It-80 (1977).

8. A. A. Frigerio, L. J. Habegsar, R. F. King, L. J. Hrover, N. A. Clark, and J. M. Coblan, Stte: A Hethodologs for Energy Pacility Site Screening and Regional Enviromental Impact Assesseent, Energy and Environental Systens Division, Argonne National Laboratory. Argonne, Illwo1s, 1975.

9. J. A. Halpern, D. M. O'Regan, and U. R. Miller, Complterized Methods in Power Plant Siting Studies, Second Ansual University of MissouriMissouri Energy Council Couference on Energy, October 7-9, 1975.

10. B. P. Hobbs and A. H. Voelker, Analytical Power Plant Siting Methodologies: A Theoretical Dismssion and Survey of Current Practice, Ond/M-5749 (1977).

11. H. A. Linstone and M. Turoff, eds., The Delphi Method: Techniques mA A-Fíicitions, Addison-Wesley Publishing Coupany, London, 1975.

12. A. H. Voelker, Power Plant Siting: An Application of the Nominal Group Process Technique, ORML/NUREG/TM-81 (1977). 
13. R. D. Duke, "Toward a General Theory of Ganing," in $z$

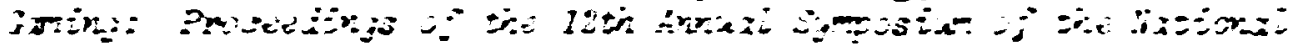

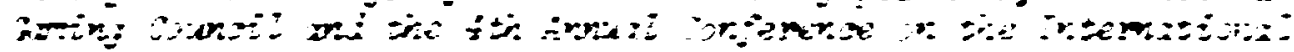

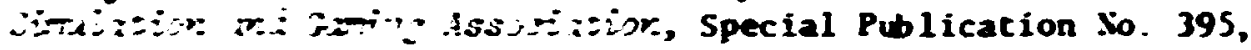
Naticnal Bureau of standards, 1974, pp. 18-19.

14. C. I. Gibbs, ed., 证 E. and F. K. Spon, Led., London, 19i4.

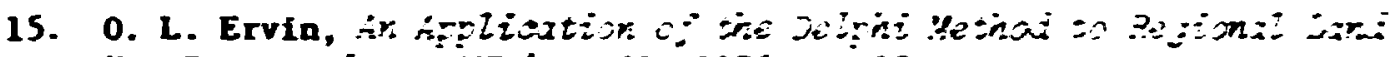
ise Eore:rstir.; ORh/sus-21, 1976, p. 15.

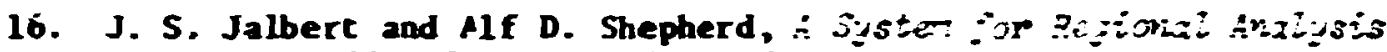

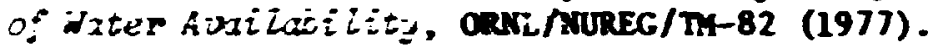

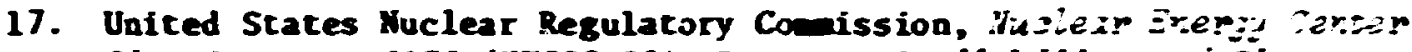

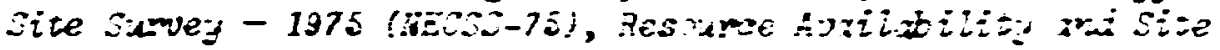
Sereening, WURES-0001, Part $V$ of $V$, Springfield, Va., 1976.

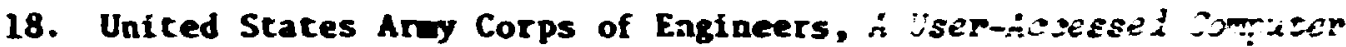

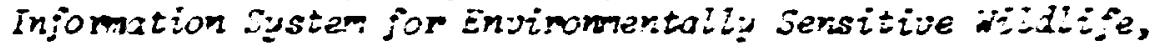
Techatcal Report No. M-74-6, U.S. Arwy Fngineer Waterways Experiment Station, Vicksburg, Miss., (June 1974).

19. J. E. Kohler, A. P. Kenneke, and B. K. Grines, te Teinnizicior

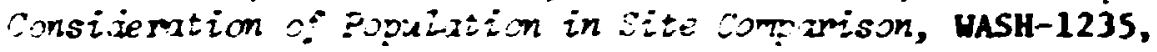
Regulatory Staff Technical Report, Directorate of Licensing, U.S. Aconic Energy Comission, Hashington, D.C., (October 1974).

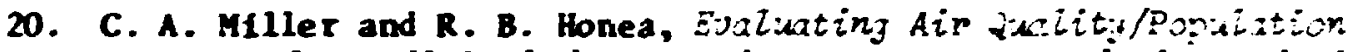
Impacts of Fossil-Fueied Paser Plonts: A Case Stuti in Frejeris: Coivity, Mxoyland, For thcoming. 
Appendix A

COAPAT IBILITY INDICES 


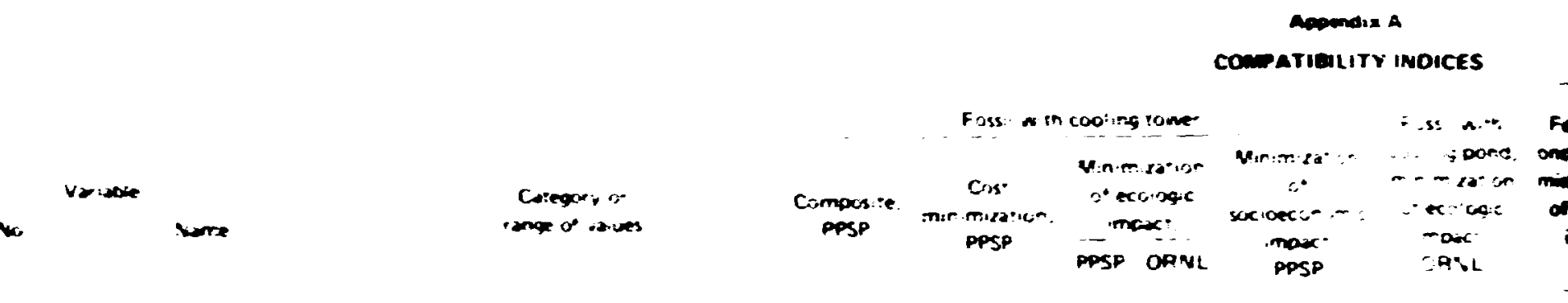

1 T:ansoc: isizin ens ransmisteron
Ciros! mees

Class 1 mites no: mexing siandaros

Cons II mores

Cass II nuters ms: meeling s:andorts

Cass 111 worers

Class lil wates no: mee: ing srancerts

Class iv wares

Coss iV maters no: meet ing sients: as

Orsie ceds open so '.shing

Pollu:en nyste nets

(bor beds oper is "ighing

Polluteri ciam terk

Aarnod

Channe soovis nisorsal site

Chonneis 27 in $42^{\circ}$

Enistiric and proposed mato inter sec trons

Mass itonsit acibirives

Utulizy lines

Sidie of Mory und iqenemal

Healin and Minn:al Hyoperie

Noiurat Pesources

Freh and Wirstite

Foresis ano Parks

Siate Police

Dmartment of Coxiecion

Gener al Serv'ces istatel

Avidion

Moss Transul Administeaion

Port Authority

Motar Veficles Artministirion

Srate Highwoys Administration

Relisiary

Ectucation

Agriculiure and Indusiry Agency

Boand of Pubdic Works

Federat Gover nment Igener all

Dedoriment of Acriculiure

Depariment of the All Force

Depariment of the Army

Cordos of Engrimers

Defor iment of the Navy

Deperiment of Conmerce

Deperimeni of Heaith. Education. and Welt are

Natconal instiluies of Health

Social Securily Administration

Depariment of Transportation

Cosst Bourd

Atomic Energy Commission

Federal Communicarions Commission

General Services Administration

NASA 


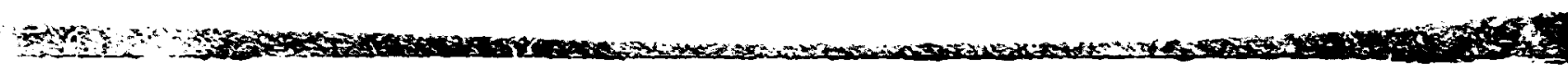

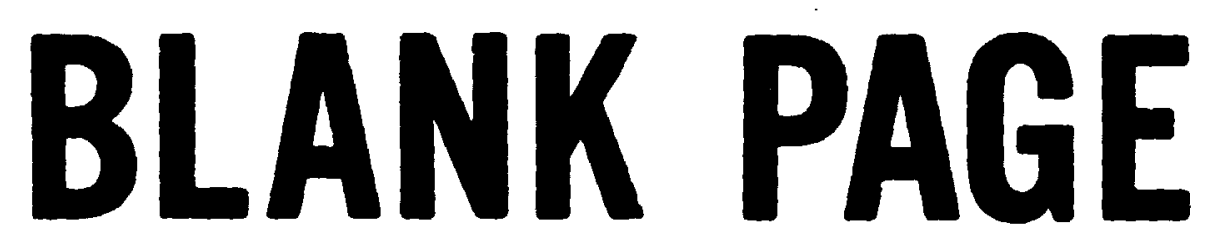




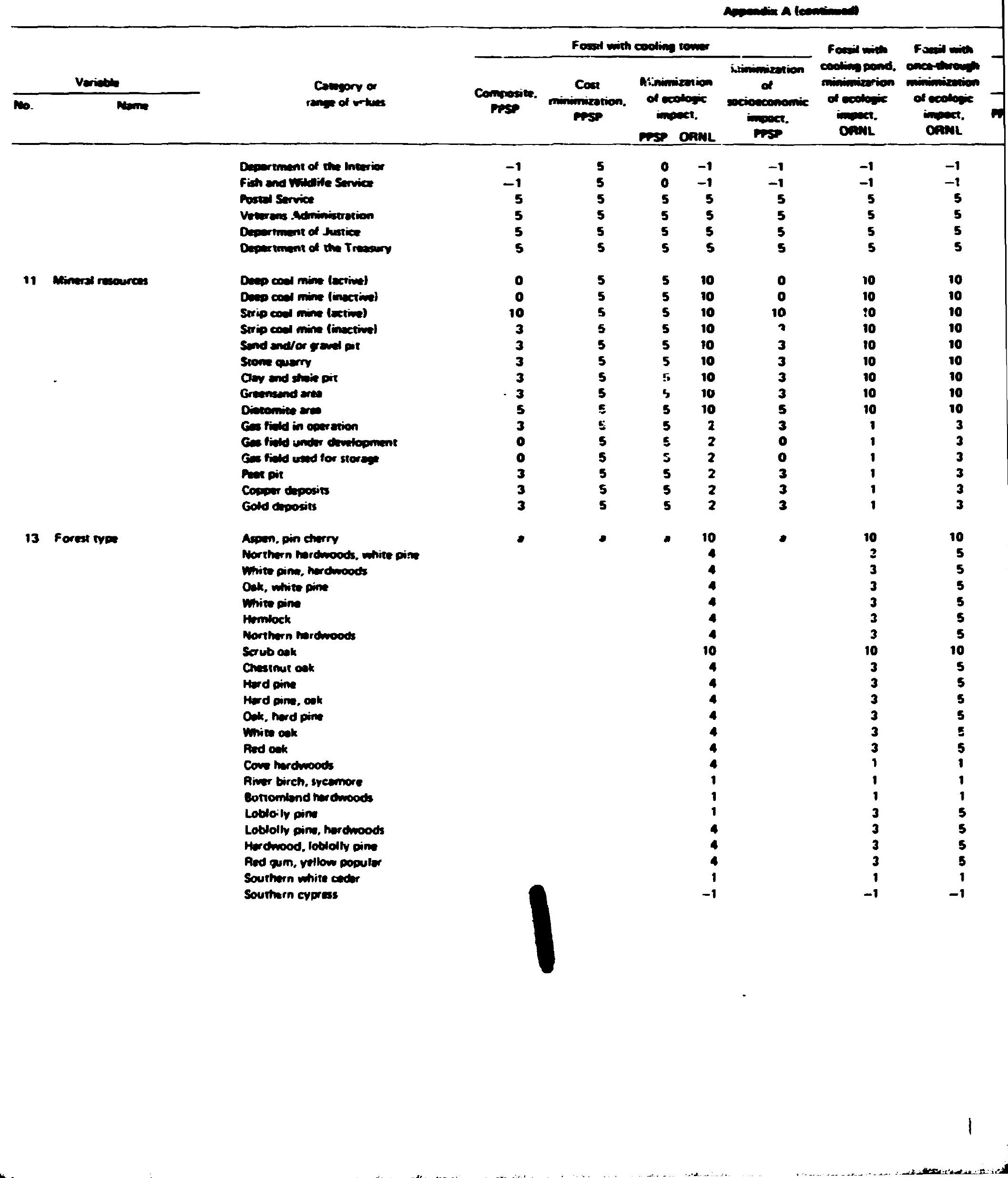





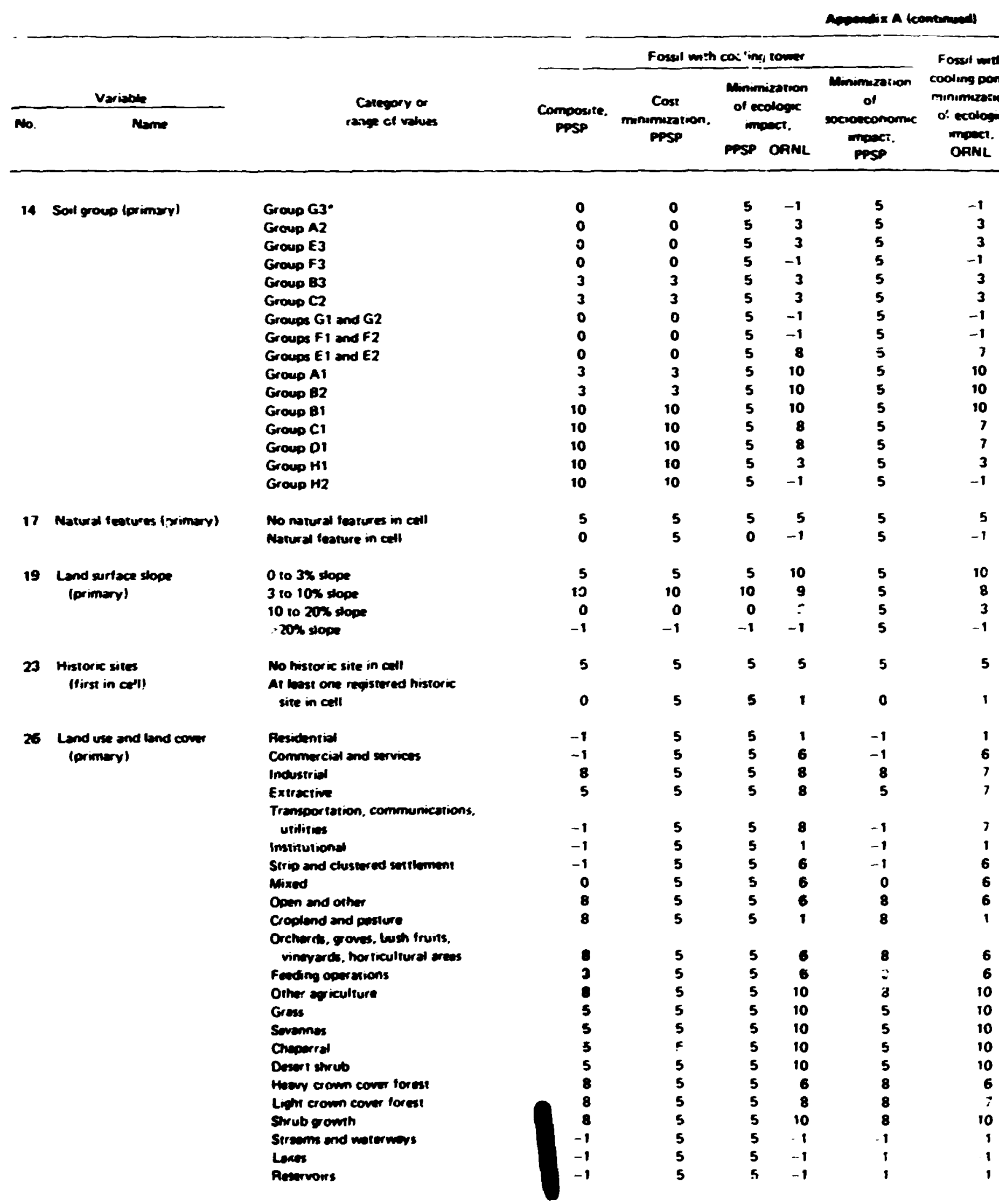




\begin{tabular}{|c|c|c|c|c|c|c|c|c|c|c|c|}
\hline \multirow{4}{*}{ 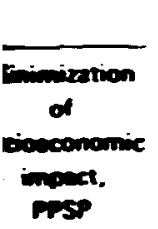 } & \multirow{4}{*}{ 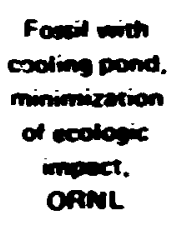 } & \multirow{4}{*}{$\begin{array}{l}\text { Foesil wh } \\
\text { once-through } \\
\text { minimization } \\
\text { of ecologic } \\
\text { ingect. } \\
\text { orvel }\end{array}$} & \multicolumn{7}{|c|}{ Nucterer with cooling tower } & \multirow{4}{*}{$\begin{array}{l}\text { Nucteser with } \\
\text { cooling pond. } \\
\text { minimization } \\
\text { of ecologic } \\
\text { impect. } \\
\text { OANL }\end{array}$} & \multirow{4}{*}{$\begin{array}{l}\text { Muctuer with } \\
\text { once-through } \\
\text { minimiza:ion } \\
\text { of ecoiogic } \\
\text { impect. } \\
\text { OANLL }\end{array}$} \\
\hline & & & \multicolumn{3}{|c|}{ Composite } & \multirow{3}{*}{$\begin{array}{c}\text { Cost } \\
\text { minimixation. } \\
\text { prsp }\end{array}$} & \multirow{2}{*}{\multicolumn{2}{|c|}{$\begin{array}{l}\text { Minimization } \\
\text { of reologic } \\
\text { impert. }\end{array}$}} & \multirow{3}{*}{$\begin{array}{l}\text { Minimination } \\
\text { of } \\
\text { socionconomic } \\
\text { inpect. } \\
\text { PPSP }\end{array}$} & & \\
\hline & & & $\operatorname{prs}$ & Nominal & Nominal & & & & & & \\
\hline & & & & & & & Prsp & OANL & & & \\
\hline 5 & -1 & -1 & 0 & -1 & -1 & $\mathbf{0}$ & 5 & -1 & 5 & -1 & -1 \\
\hline $\mathbf{5}$ & 3 & 4 & $\mathbf{0}$ & 0 & $\mathbf{0}$ & $\mathbf{0}$ & 5 & 3 & 5 & 3 & 4 \\
\hline $\mathbf{5}$ & 3 & 4 & $\mathbf{0}$ & 2 & 2 & $\mathbf{0}$ & 5 & 3 & 5 & 3 & 4 \\
\hline 5 & -1 & -1 & $\mathbf{0}$ & 3 & 3 & $\mathbf{0}$ & 5 & -1 & 5 & -1 & -1 \\
\hline $\mathbf{5}$ & 3 & 4 & 5 & 4 & 4 & $\mathbf{5}$ & 5 & 3 & 5 & 3 & 4 \\
\hline $\mathbf{5}$ & 3 & 4 & 5 & 7 & 7 & 5 & 5 & 3 & 5 & 3 & 4 \\
\hline $\mathbf{s}$ & -1 & -1 & 0 & $\mathbf{0}$ & 0 & 0 & 5 & -1 & 5 & -1 & -1 \\
\hline 5 & -1 & -1 & 0 & 2 & 2 & 0 & 5 & -1 & 5 & -1 & -1 \\
\hline 5 & 7 & 8 & 0 & 3 & 3 & $\mathbf{0}$ & 5 & 8 & 5 & 7 & 8 \\
\hline 5 & 10 & 10 & 5 & 4 & 4 & 5 & 5 & 10 & 5 & 10 & 10 \\
\hline 5 & 10 & 10 & 5 & 7 & 7 & 5 & $\mathbf{5}$ & 10 & 5 & 10 & 10 \\
\hline 5 & 10 & 10 & 10 & 8 & 8 & 10 & 5 & 10 & 5 & 10 & 10 \\
\hline 5 & 7 & 8 & 10 & 10 & 10 & 10 & 5 & 8 & 5 & 7 & -8 \\
\hline 5 & 7 & 8 & 10 & 10 & 10 & 10 & 5 & 8 & $\mathbf{s}$ & 7 & 8 \\
\hline 5 & 3 & 4 & 10 & 10 & 10 & 10 & 5 & 3 & 5 & 3 & 4 \\
\hline 5 & -1 & -1 & 10 & 10 & 10 & 10 & 5 & -1 & 5 & -1 & .1 \\
\hline $\mathbf{5}$ & 5 & 5 & 5 & 10 & 10 & 5 & 5 & 5 & 5 & 5 & 5 \\
\hline 5 & -1 & -1 & $\mathbf{0}$ & 0 & 0 & 5 & 0 & -1 & 5 & -1 & -1 \\
\hline 5 & 10 & 10 & 5 & 10 & 10 & 5 & 5 & 10 & 5 & 10 & 10 \\
\hline 5 & 8 & 10 & 10 & 10 & 10 & 10 & 10 & 9 & 5 & 8 & 10 \\
\hline 5 & 3 & 4 & 0 & 5 & 5 & 0 & $\mathbf{0}$ & 3 & 5 & 3 & 4 \\
\hline 5 & -1 & -1 & -1 & 0 & 0 & -1 & -1 & -1 & 5 & -1 & -1 \\
\hline 5 & 5 & 5 & 5 & 10 & 10 & 5 & 5 & 5 & 5 & 5 & 5 \\
\hline 0 & 1 & 1 & 0 & 0 & 0 & 5 & 5 & 1 & 0 & 1 & 1 \\
\hline-1 & 1 & 1 & -1 & 0 & 0 & 5 & 5 & -1 & -1 & -1 & -1 \\
\hline-1 & 6 & 6 & -1 & 0 & 0 & 5 & 5 & 1 & -1 & 1 & 1 \\
\hline 8 & 7 & 8 & 3 & 2 & 2 & 5 & 5 & 4 & 3 & 3 & 4 \\
\hline 5 & 7 & 8 & 5 & 5 & 5 & 5 & 5 & 4 & 5 & 3 & 4 \\
\hline-1 & 7 & 8 & -1 & 5 & 5 & 5 & 5 & 4 & -1 & 3 & 4 \\
\hline-1 & 1 & 1 & -1 & 0 & 0 & 5 & 5 & -1 & -1 & -1 & -1 \\
\hline-1 & 3 & 6 & -1 & 0 & 0 & 5 & 5 & $\mathbf{I}$ & -1 & 1 & 1 \\
\hline 0 & 6 & 6 & $\mathbf{0}$ & 0 & 0 & 5 & 5 & 1 & 0 & 1 & 1 \\
\hline 8 & 8 & 6 & 8 & 1 & 1 & 5 & 5 & $\mathbf{I}$ & 8 & $\mathbf{I}$ & 1 \\
\hline 8 & 1 & 1 & 8 & 5 & 5 & 5 & 5 & -1 & 8 & -1 & -1 \\
\hline
\end{tabular}

6
10
10
10
10
10
6
10
-8
-
-

$\begin{array}{rrrr}6 & 8 & 5 & 5 \\ 6 & 3 & 5 & 5 \\ 10 & 8 & 5 & 5 \\ 10 & 5 & 8 & 8 \\ 10 & 5 & 8 & 8 \\ 10 & 5 & 8 & 8 \\ 10 & 5 & 8 & 8 \\ 6 & 8 & 4 & 4 \\ 8 & 8 & 4 & 4 \\ 10 & 8 & 8 & 8 \\ -1 & -1 & -1 & -1 \\ -1 & -1 & -1 & -1 \\ -1 & -1 & -1 & -1\end{array}$

$\begin{array}{rrrr}5 & 5 & 1 & 8 \\ 5 & 5 & 1 & 3 \\ 5 & 5 & 10 & 8 \\ 5 & 5 & 10 & 5 \\ 5 & 5 & 10 & 5 \\ 5 & 5 & 10 & 5 \\ 5 & 5 & 10 & 5 \\ 5 & 5 & 1 & 8 \\ 5 & 5 & 4 & 8 \\ 5 & 5 & 10 & 8 \\ 5 & 5 & -1 & -1 \\ 5 & 5 & -1 & -1 \\ 5 & 5 & -1 & -1\end{array}$

$\begin{array}{rr}i & 1 \\ 1 & 1 \\ 10 & 10 \\ 10 & 10 \\ 10 & 10 \\ 10 & 10 \\ 1 & 10 \\ 3 & 1 \\ 10 & 4 \\ -1 & 10 \\ -1 & -1 \\ -1 & -1\end{array}$




\begin{tabular}{|c|c|c|c|c|c|c|c|c|c|c|}
\hline \multirow{2}{*}{\multicolumn{2}{|c|}{ various }} & \multirow{4}{*}{$\begin{array}{l}\text { Couspory or } \\
\text { remes of vatues }\end{array}$} & \multicolumn{5}{|c|}{ Fosin with croling tower } & \multirow{4}{*}{$\begin{array}{l}\text { Fossil with } \\
\text { cooling pond. } \\
\text { minimiration } \\
\text { of coologic } \\
\text { OPpoct. } \\
\text { OANL }\end{array}$} & \multirow{4}{*}{$\begin{array}{l}\text { Fossil with } \\
\text { once-ithrowy } \\
\text { minimuzation } \\
\text { If ecologic } \\
\text { movet. } \\
\text { OANL }\end{array}$} & \multirow{4}{*}{$\overline{\text { mpsp }}$} \\
\hline & & & \multirow{3}{*}{$\begin{array}{l}\text { Composite. } \\
\text { ppse }\end{array}$} & \multirow{3}{*}{$\begin{array}{l}\text { Cost - } \\
\text { minimization. } \\
\text { Ppsp }\end{array}$} & \multirow{2}{*}{\multicolumn{2}{|c|}{$\begin{array}{l}\text { Minimization } \\
\text { of ecoloyic } \\
\text { impoct. }\end{array}$}} & \multirow{3}{*}{$\begin{array}{l}\text { Amimiration } \\
\text { of } \\
\text { sncionconomic } \\
\text { inpoct. } \\
\text { Prsp? }\end{array}$} & & & \\
\hline No. & (1) & & & & & & & & & \\
\hline & & & & & IrsP & OANL & & & & \\
\hline & & Bry and estureries & -1 & 5 & 5 & -1 & -1 & -1 & -1 & -1 \\
\hline & & Other wow bodes & -1 & 5 & $\mathbf{5}$ & -1 & -1 & -1 & -1 & -1 \\
\hline & & Vesponed vetiones & -1 & 5 & 5 & -1 & -1 & -1 & -1 & -1 \\
\hline & & 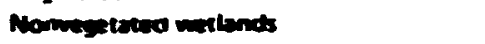 & -1 & 5 & 5 & -1 & -1 & -1 & -1 & -1 \\
\hline & & Sedt lats & -1 & 5 & $\mathbf{5}$ & 8 & -1 & 7 & 8 & -1 \\
\hline & & Beaches & -1 & 5 & 5 & 1 & -1 & 1 & $\mathbf{1}$ & -1 \\
\hline & & Send oxther than beceches & 8 & 5 & 5 & 6 & 8 & 6 & 6 & 10 \\
\hline & & Bere exposed soch & 8 & 5 & 5 & 10 & 8 & 10 & 10 & 10 \\
\hline & & Other berren land & 8 & 5 & 5 & 10 & 8 & 10 & 10 & 10 \\
\hline $\mathbf{2}$ & Phemed hand un and tand cover & Pesidentiel & -1 & 5 & 5 & $\mathbf{1}$ & -1 & $\mathbf{1}$ & 1 & -1 \\
\hline & & Commerciel and services & -1 & 5 & 5 & 6 & -1 & 6 & $\mathbf{6}$ & -1 \\
\hline & & Industried & 8 & 5 & 5 & 8 & 8 & 7 & $\mathbf{a}$ & 3 \\
\hline & & Trameportution, communications. & & & & & & & & \\
\hline & & end utivities & -1 & 5 & 5 & 8 & -1 & 7 & 8 & -1 \\
\hline & & Institutioned & -1 & 5 & 5 & 1 & -1 & 1 & $\mathbf{1}$ & -1 \\
\hline & & Strip and chetwed settlement & -1 & 5 & 5 & 6 & -1 & 6 & 6 & $-i$ \\
\hline & & Open and other & 8 & 5 & $\mathbf{5}$ & 6 & 8 & 6 & 6 & $\mathbf{8}$ \\
\hline & & Agriculturd hand & 8 & 5 & 5 & 6 & 8 & 6 & 6 & 8 \\
\hline & & Cropland and posture & 8 & 5 & 5 & $\mathbf{1}$ & 8 & $\mathbf{1}$ & 1 & 8 \\
\hline & & Forest land & 8 & 5 & 5 & 8 & 8 & 8 & 8 & 8 \\
\hline & & nover & -1 & 5 & 5 & -1 & -1 & -1 & -1 & -1 \\
\hline 32 & Mighurieys and proponed & No maior himgromen in call & 5 & 5 & 5 & $a$ & $\mathbf{5}$ & • & a & 5 \\
\hline & highnows & Four teme highmoy or interstote & -1 & 5 & $\mathbf{5}$ & & -1 & & & -1 \\
\hline & & Mujor twotbone nighwer & -1 & $\mathbf{5}$ & $\mathbf{5}$ & & -1 & & & -1 \\
\hline & & $\begin{array}{l}\text { Proposed four tane highwoy } \\
\text { Inver soctions of interstote and }\end{array}$ & $\mathbf{0}$ & 5 & 5 & & $\mathbf{0}$ & & & 0 \\
\hline & & 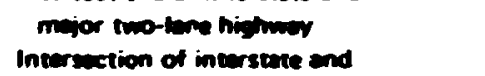 & -1 & 5 & 5 & & -1 & & & -1 \\
\hline & & 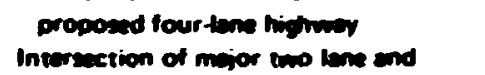 & -1 & $\mathbf{5}$ & $\mathbf{5}$ & & -1 & & & -1 \\
\hline & & proposed four there linghury & -1 & 5 & 5 & & -1 & & & -1 \\
\hline $\mathbf{3 3}$ & Saismiciry & Activity beel I & 10 & 10 & 5 & $\bullet$ & 5 & $\bullet$ & a & 10 \\
\hline & & Activity hed II & 3 & 3 & 5 & & 5 & & & 3 \\
\hline & & Activing berd III & $\mathbf{0}$ & $\mathbf{0}$ & 5 & & 5 & & & $\mathbf{0}$ \\
\hline 34 & 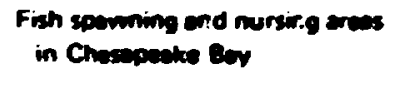 & 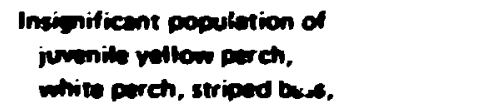 & & & & & & & & \\
\hline & & $\begin{array}{l}\text { of bluetion } \\
\text { Fias spowing and nursing areas }\end{array}$ & - & - & - & - & - & - & - & $\bullet$ \\
\hline 35 & 30 mile sPF & 0100.20 & 10 & 5 & 5 & & 10 & & & 10 \\
\hline & & 0.20 to 0.50 & 5 & 5 & 5 & & 5 & & & 5 \\
\hline & & 0.50101 .00 & 5 & 5 & 5 & & $\mathbf{5}$ & & & -1 \\
\hline & & 1.00 to 9.00 & 5 & 5 & 5 & & 5 & & & -1 \\
\hline 33 & Endengered soveins & No mompered species resietered & 5 & $\mathbf{s}$ & 5 & $\mathbf{5}$ & 5 & 5 & 5 & $\mathbf{5}$ \\
\hline & & Generelized ceve rejion of Indiens ber & $\mathbf{0}$ & 5 & $\mathbf{0}$ & -1 & 5 & -1 & -1 & $\mathbf{0}$ \\
\hline & & Estimuced posidie remp of Indiens ben & $\mathbf{0}$ & $\mathbf{5}$ & D & 4 & 5 & 4 & 4 & $\mathbf{0}$ \\
\hline & & Oberined locetion of Indiend bet & -1 & 5 & -1 & -1 & 5 & -1 & -1 & -1 \\
\hline
\end{tabular}





\begin{tabular}{|c|c|c|c|c|c|c|c|c|}
\hline \multicolumn{9}{|c|}{ Appendix A lcontim } \\
\hline \multirow{2}{*}{\multicolumn{2}{|c|}{ Varrable }} & \multirow{4}{*}{$\begin{array}{l}\text { Calegory or } \\
\text { imge of values }\end{array}$} & \multicolumn{5}{|c|}{ Forsil with cooling tomer } & \multirow{4}{*}{$\begin{array}{l}\text { Fussi: wit } \\
\text { Croing Do } \\
\text { m:nimizar } \\
\text { o! ecoloy } \\
\text { Impax! } \\
\text { ORNL }\end{array}$} \\
\hline & & & \multirow{3}{*}{$\begin{array}{c}\text { Composite. } \\
\text { PPSP }\end{array}$} & \multirow{3}{*}{$\begin{array}{l}\text { Cost } \\
\text { minimizzicon. } \\
\text { ppsp }\end{array}$} & \multirow{2}{*}{\multicolumn{2}{|c|}{$\begin{array}{l}\text { Minimuzarion } \\
\text { of ecologic } \\
\text { impact. }\end{array}$}} & \multirow{3}{*}{$\begin{array}{c}\text { Minimization } \\
\text { of } \\
\text { socioeconomic } \\
\text { impact. } \\
\text { PPSP }\end{array}$} & \\
\hline No. & Narme & & & & & & & \\
\hline & & & & & PPSP & OANL & & \\
\hline \multirow[t]{6}{*}{37} & Excavatrot requirements & No dis avaibable & 5 & 5 & 5 & 2 & 5 & d \\
\hline & & Blasting requ ired & 10 & 10 & 5 & & 5 & \\
\hline & & Power grading and some blasting & & & & & & \\
\hline & & required & 8 & 8 & 5 & & 5 & \\
\hline & & Pover gading required & 2 & 2 & 5 & & 5 & \\
\hline & & Deedging required & $\mathbf{0}$ & 0 & 5 & & 5 & \\
\hline \multirow[t]{5}{*}{38} & Overburden thickness & No dita mailatle & 5 & 5 & 5 & a & 5 & 2 \\
\hline & & Thin over bur den & 8 & 8 & 5 & & 5 & \\
\hline & & Medium over burden & 10 & 10 & 5 & & 5 & \\
\hline & & Thick overburden & 2 & 2 & 5 & & 5 & \\
\hline & & Variable over burden thickness & 5 & 5 & 5 & & 5 & \\
\hline \multirow[t]{7}{*}{39} & Aquiter recharge zones & $\begin{array}{l}\text { Not an aquiter recharge rone } \\
\text { Hydrologe unit l of Piedmant }\end{array}$ & 11) & 5 & 10 & 10 & 5 & 10 \\
\hline & & and Appolachian Provinces & $\mathbf{0}$ & 5 & $\mathbf{0}$ & -1 & 5 & $\cdots 1$ \\
\hline & & Hydrotogic unit II of Predonont & & & & & & \\
\hline & & $\begin{array}{l}\text { and Appalachian Provinces } \\
\text { Hydtologic unit III of Predmont }\end{array}$ & 6 & 5 & 6 & 4 & 5 & 3 \\
\hline & & & 10 & 5 & 10 & 8 & 5 & 7 \\
\hline & & Sandy aquiters of the Coastal & & J & & & & \\
\hline & & Plain Province & 0 & 5 & 0 & -1 & 5 & -1 \\
\hline \multirow[t]{4}{*}{40} & Five mile SPF & 0.0100 .20 & 10 & 5 & 5 & $a$ & 10 & $a$ \\
\hline & & 0.20 to 0.50 & 5 & 5 & 5 & & 5 & \\
\hline & & 0.50101 .00 & 5 & 5 & 5 & & 5 & \\
\hline & & 1.00 10 99.0 & 5 & 5 & 5 & & 5 & \\
\hline \multirow[t]{13}{*}{42} & Population density & 0 10 16 personsisq mile & 10 & 5 & 5 & $-!$ & 10 & -1 \\
\hline & & 16 to 34 persons/sq mile & 9 & 5 & 5 & -1 & 9 & $\therefore$ \\
\hline & & 34 to 64 persons/sq mile & 8 & 5 & 5 & 1 & 8 & 1 \\
\hline & & 64 to 75 persons/sa mile & 7 & 5 & 5 & $i$ & 7 & 1 \\
\hline & & 75 to 128 per sonsisq mile & 7 & 5 & 5 & 6 & 7 & 6 \\
\hline & & 128 to 150 per sons/sq mile & 6 & 5 & 5 & 6 & 6 & 6 \\
\hline & & 150 to 256 persons/sq mile & 6 & 5 & 5 & 8 & 6 & 8 \\
\hline & & 256 to 300 persons $/ s 9$ mile & 5 & 5 & 5 & 8 & 5 & 8 \\
\hline & & 300 to 512 persons $/$ sq mile & 5 & 5 & 5 & 10 & 5 & 10 \\
\hline & & 512 to 600 persons/sq mile & 5 & 5 & 5 & 10 & 5 & 10 \\
\hline & & 600 10 1200 per $1013 / 30$ mile & 5 & 5 & 5 & 10 & 5 & 10 \\
\hline & & 1200 io 2400 persons/sq mile & 5 & 5 & 5 & 6 & 5 & 8 \\
\hline & & .2400 persons/sq mile & 5 & 5 & 5 & 6 & 5 & 6 \\
\hline \multirow[t]{5}{*}{43} & Proximity to highweys & 0 to 1 cell & 10 & 10 & 10 & 10 & 5 & 10 \\
\hline & & 1 to 2 cells & 10 & 10 & 10 & 8 & 5 & 8 \\
\hline & & 2 to 5 cells & 5 & 5 & 5 & 5 & 5 & 5 \\
\hline & & 5 to 10 celk & 3 & 3 & 3 & 3 & 5 & 3 \\
\hline & & $\because 10$ cells & 0 & $\mathbf{0}$ & 0 & 0 & 5 & 0 \\
\hline \multirow[t]{5}{*}{44} & Proximity to railrood & 0 to 1 cell & 10 & 10 & 10 & 10 & 5 & 10 \\
\hline & & 1 to 2 cells & 10 & 10 & 10 & 8 & 5 & 8 \\
\hline & & 2 to 5 cells & 8 & 8 & 8 & 5 & 5 & 5 \\
\hline & & 5 to 10 calls & 5 & 5 & 5 & 3 & 5 & 3 \\
\hline & & 10 calls & 0 & 0 & 0 & 0 & 5 & 0 \\
\hline
\end{tabular}


Apoendix a (continued)

\begin{tabular}{|c|c|c|c|c|c|c|c|c|c|c|c|c|c|}
\hline \multicolumn{3}{|c|}{ poling tower } & \multirow{3}{*}{$\begin{array}{l}\text { Fossil with } \\
\text { cooling pond. } \\
\text { minimizarien } \\
\text { of ecologic } \\
\text { impac: } \\
\text { ORNL }\end{array}$} & \multirow{3}{*}{$\begin{array}{l}\text { Fossil with } \\
\text { once-through } \\
\text { minimization } \\
\text { of ecolsgic } \\
\text { impact. } \\
\text { ORNL }\end{array}$} & \multicolumn{7}{|c|}{ Nuclear with cooling romer } & \multirow{3}{*}{$\begin{array}{l}\text { Nuclear with } \\
\text { cooling pond. } \\
\text { minimization } \\
\text { of ecologic } \\
\text { impacl. } \\
\text { CRNL }\end{array}$} & \multirow{3}{*}{$\begin{array}{l}\text { Nuclear mith } \\
\text { once-througt } \\
\text { minimiration } \\
\text { ot ecologic } \\
\text { Impact. } \\
\text { ORNL }\end{array}$} \\
\hline \multirow{2}{*}{\multicolumn{2}{|c|}{$\begin{array}{l}\text { Imimization } \\
\text { of ecolngic } \\
\text { impact. }\end{array}$}} & \multirow{2}{*}{$\begin{array}{l}\text { Minimization } \\
\text { of } \\
\text { soc:oeconomic } \\
\text { impact, } \\
\text { PPSPP }\end{array}$} & & & \multicolumn{3}{|c|}{ Composite } & \multirow{2}{*}{$\begin{array}{c}\text { Cost } \\
\text { minimization. } \\
\text { Ppsp }\end{array}$} & \multicolumn{2}{|c|}{$\begin{array}{l}\text { Aamimization } \\
\text { of ecolcgic } \\
\text { inouct. }\end{array}$} & \multirow{2}{*}{$\begin{array}{l}\text { Minirization } \\
\text { of } \\
\text { socioeconomic } \\
\text { inpact. } \\
\text { PPSP }\end{array}$} & & \\
\hline & & & & & PPSP & $\begin{array}{l}\text { Nominal } \\
\text { group } 1\end{array}$ & $\begin{array}{l}\text { Nominal } \\
\text { goup } 2\end{array}$ & & & & & & \\
\hline $\begin{array}{l}5 \\
5\end{array}$ & $a$ & $\begin{array}{l}5 \\
5\end{array}$ & 3 & 2 & $\begin{array}{r}5 \\
10\end{array}$ & $\begin{array}{r}5 \\
10\end{array}$ & $\begin{array}{r}5 \\
10\end{array}$ & $\begin{array}{r}5 \\
10\end{array}$ & $\begin{array}{l}5 \\
5\end{array}$ & $\mathbf{d}$ & $\begin{array}{l}5 \\
5\end{array}$ & 2 & 2 \\
\hline 5 & & 5 & & & 8 & $\mathbf{8}$ & 8 & 8 & 5 & & 5 & & \\
\hline 5 & & 5 & & & 2 & 2 & 2 & 2 & 5 & & 5 & & \\
\hline 5 & & 5 & & & 0 & 0 & 0 & 0 & 5 & & 5 & & \\
\hline 5 & 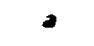 & 5 & $a$ & 2 & 5 & 5 & 5 & 5 & 5 & a & 5 & a & a \\
\hline 5 & & 5 & & & 8 & 8 & 8 & 8 & 5 & & 5 & & \\
\hline 5 & & 5 & & & 10 & 10 & 10 & 10 & 5 & & 5 & & \\
\hline 5 & & 5 & & & 2 & 2 & 2 & 2 & 5 & & 5 & & \\
\hline 5 & & 5 & & & 5 & 5 & 5 & 5 & 3 & & 5 & & \\
\hline 10 & 10 & 5 & 10 & 10 & 10 & 10 & 10 & 5 & IC & 10 & 5 & 10 & $? 0$ \\
\hline $\mathbf{0}$ & -1 & 5 & -1 & -1 & $\mathbf{0}$ & $\mathbf{0}$ & 0 & 5 & $\mathbf{0}$ & -1 & 5 & -1 & --1 \\
\hline 6 & 4 & 5 & 3 & 5 & 6 & 6 & 6 & 5 & 6 & 2 & 5 & 1 & 3 \\
\hline 10 & 8 & 5 & 7 & 9 & 10 & 10 & 10 & 5 & 10 & 7 & 5 & 6 & 8 \\
\hline 0 & -1 & 5 & $\ldots 1$ & -1 & 0 & 0 & 0 & $\leq$ & 0 & -1 & 5 & -1 & -1 \\
\hline 5 & a & 10 & 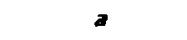 & a & 10 & 10 & 10 & 5 & 5 & a & 10 & a & ג \\
\hline 5 & & $\mathbf{b}$ & & & 5 & 5 & 5 & 5 & 5 & & 5 & & \\
\hline 5 & & 5 & & & 0 & -1 & -1 & 5 & 5 & & 0 & & \\
\hline 5 & & 5 & & & 0 & -1 & -1 & 5 & 5 & & 0 & & \\
\hline 5 & -1 & 10 & -1 & -1 & 1. & 10 & 10 & 5 & 5 & -1 & 10 & -1 & -1 \\
\hline 5 & -1 & 9 & -1 & -1 & 8 & 8 & 8 & 5 & 5 & -1 & 8 & -1 & -1 \\
\hline 5 & 1 & 8 & 1 & 1 & 6 & 6 & 6 & 5 & 5 & -1 & 6 & -1 & -1 \\
\hline 5 & 1 & 7 & 1 & 1 & 4 & 4 & 4 & 5 & 5 & -1 & 4 & -1 & -1 \\
\hline 5 & 6 & 7 & 6 & 6 & 4 & 4 & 4 & 5 & 5 & 4 & 4 & 4 & 4 \\
\hline 5 & 6 & 6 & 6 & 6 & 2 & 2 & 2 & 5 & 5 & 4 & 2 & 4 & 4 \\
\hline 5 & 8 & 6 & 8 & 8 & 2 & 2 & 2 & 5 & 5 & 8 & 2 & 8 & 8 \\
\hline 15 & 8 & 5 & 8 & B & 0 & 0 & 0 & 5 & 5 & 8 & 0 & 8 & 8 \\
\hline 5 & 10 & 5 & 10 & 10 & 0 & 0 & 0 & 5 & 5 & 10 & 0 & 10 & 10 \\
\hline 5 & 10 & 5 & 10 & 10 & 0 & -1 & -1 & 5 & 5 & 10 & 0 & 10 & 10 \\
\hline 6 & 10 & 5 & 10 & 10 & 0 & -1 & -1 & 5 & 5 & 10 & 0 & 10 & 10 \\
\hline b & 8 & 5 & B & 8 & 0 & -1 & -1 & 5 & 5 & 4 & $\mathbf{0}$ & 4 & 4 \\
\hline 6 & 6 & 5 & 6 & 6 & 0 & -1 & -1 & 5 & 5 & -1 & $n$ & -1 & -1 \\
\hline 3 & 10 & 5 & 10 & 10 & 5 & 0 & 0 & 5 & 5 & 10 & 5 & 10 & 10 \\
\hline 0 & 8 & 5 & 8 & 8 & 10 & 3 & 3 & 10 & 10 & 8 & 5 & 8 & 8 \\
\hline 6 & 5 & 5 & 5 & 5 & 5 & 10 & 10 & 5 & 5 & 5 & 5 & 5 & 5 \\
\hline a & 3 & 5 & 3 & 3 & 3 & 8 & 8 & 3 & 3 & 3 & 5 & 3 & 3 \\
\hline 5 & 0 & 5 & 0 & 0 & 0 & 6 & 6 & 0 & 0 & 0 & 5 & 0 & 0 \\
\hline 3 & 10 & 5 & 10 & 10 & 10 & 5 & 5 & 10 & 10 & 10 & 5 & 10 & 10 \\
\hline 9 & 8 & 5 & 8 & 8 & 10 & 10 & 10 & 10 & 10 & 8 & 5 & 8 & 8 \\
\hline & 5 & 5 & 5 & 5 & 5 & 9 & 9 & 5 & 5 & 5 & 5 & 5 & 5 \\
\hline 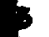 & 3 & 5 & 3 & 3 & 3 & 5 & 5 & 3 & 3 & 3 & 5 & 3 & 3 \\
\hline & 0 & 5 & 0 & 0 & 0 & 0 & 0 & 0 & 0 & 0 & 5 & 0 & 0 \\
\hline
\end{tabular}





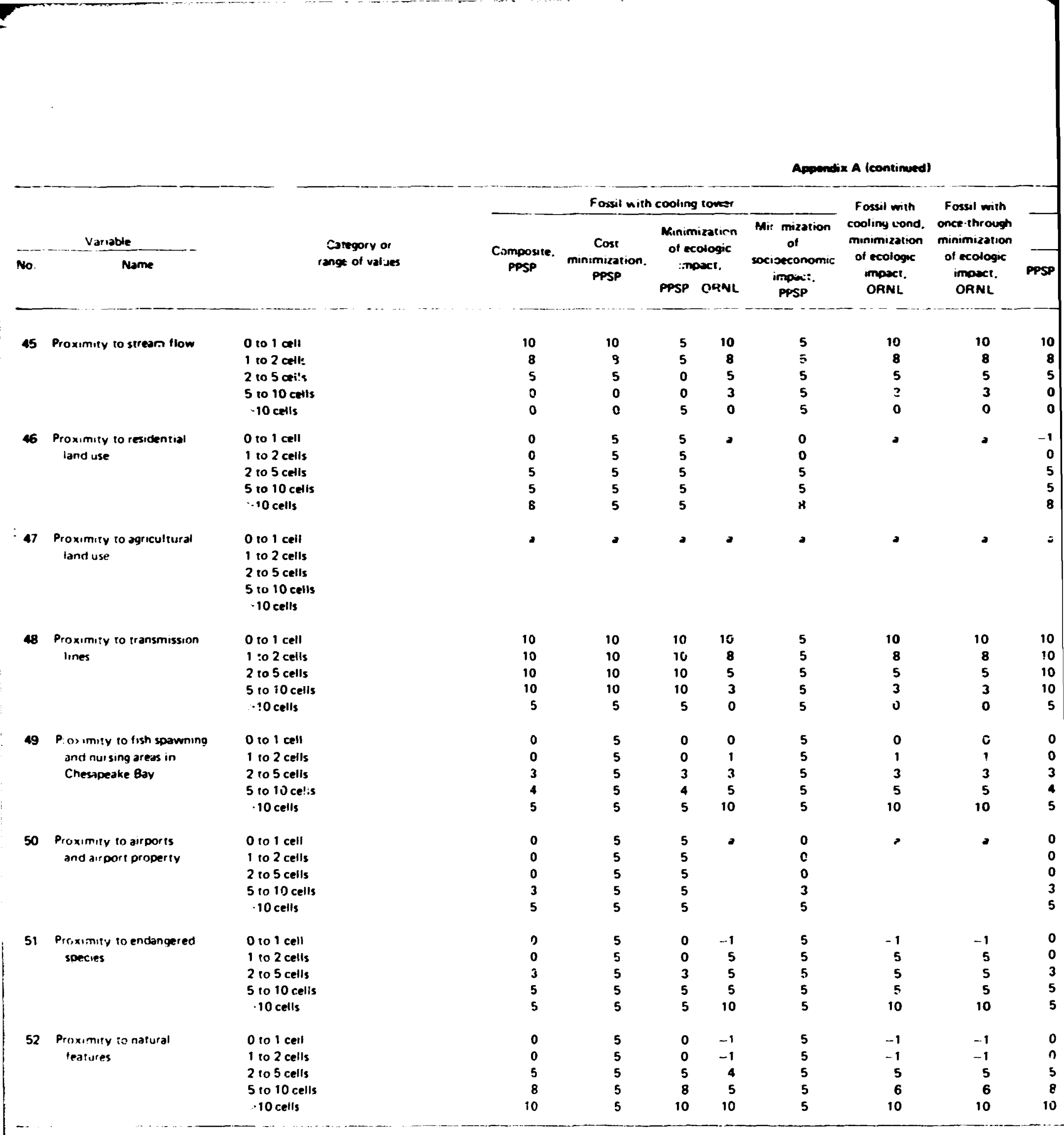

"Catepory net inclialed is respondent. 
Nurtear 9

Mominal mid

group?

10

10

0

$-1$

0

3

3
6
10

3

4

5
10

10

10

0

5

$-1$

-1
-1
2

5
10

0

0

3

5
10

0

0

3

10

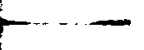




\begin{tabular}{|c|c|c|c|c|c|c|c|c|c|c|c|}
\hline \multirow{3}{*}{$\begin{array}{l}\text { Pixation } \\
\text { of } \\
\text { ponomic } \\
\text { sect. }\end{array}$} & \multirow{3}{*}{$\begin{array}{l}\text { Fossil with } \\
\text { cooling pond. } \\
\text { minimization } \\
\text { of ecologic } \\
\text { impect. } \\
\text { ORidL }\end{array}$} & \multirow{3}{*}{$\begin{array}{l}\text { Fossil with } \\
\text { once-throwyh } \\
\text { mirimizaticn } \\
\text { of ecotogic } \\
\text { impact. } \\
\text { ORNL }\end{array}$} & \multicolumn{7}{|c|}{ Huclear with cooling romer } & \multirow{3}{*}{$\begin{array}{l}\text { Nuclear with } \\
\text { cooling pond. } \\
\text { minimization } \\
\text { of ecologrc } \\
\text { impoct. } \\
\text { ORNL }\end{array}$} & \multirow{3}{*}{$\begin{array}{l}\text { Nuctear mith } \\
\text { once-through } \\
\text { minimization } \\
\text { of ecologic } \\
\text { "npact. } \\
\text { ORNL }\end{array}$} \\
\hline & & & \multicolumn{3}{|c|}{ Composite } & \multirow{2}{*}{$\begin{array}{c}\text { Cost } \\
\text { minimization. } \\
\text { Ppsp }\end{array}$} & \multicolumn{2}{|c|}{$\begin{array}{l}\text { Minimization } \\
\text { of ecologic } \\
\text { impace. }\end{array}$} & \multirow{2}{*}{$\begin{array}{l}\text { Minimization } \\
\text { of } \\
\text { scciocenomic } \\
\text { impert. } \\
\text { PPSP }\end{array}$} & & \\
\hline & & & PPSP & $\begin{array}{l}\text { Nominal } \\
\text { goup } 1\end{array}$ & $\begin{array}{l}\text { Plominal } \\
\text { goup } 2\end{array}$ & & & $\begin{array}{l}\text { pace. } \\
\text { ORNL }\end{array}$ & & & \\
\hline $\mathbf{5}$ & 10 & 10 & 10 & 10 & 10 & 10 & 5 & 10 & 5 & 10 & 10 \\
\hline 5 & 8 & 8 & 8 & 10 & 10 & 8 & 5 & 8 & 5 & 8 & 8 \\
\hline j & 5 & 5 & 5 & 7 & 7 & 5 & $\mathbf{0}$ & 5 & 5 & 5 & 5 \\
\hline 5 & 3 & 3 & $\mathbf{0}$ & $\mathbf{0}$ & $\mathbf{0}$ & $\mathbf{0}$ & $\mathbf{0}$ & 3 & 0 & 3 & 3 \\
\hline 5 & 0 & 0 & 0 & -1 & -1 & 0 & 5 & $\mathbf{0}$ & د & 0 & 0 \\
\hline 0 & 2 & 2 & -1 & 0 & 0 & 5 & 5 & , & -1 & 2 & \& \\
\hline $\mathbf{0}$ & & & $\mathbf{0}$ & 0 & 0 & 5 & 5 & & $\mathbf{0}$ & & \\
\hline 5 & & & 5 & 3 & 3 & 5 & 5 & & 5 & & \\
\hline 5 & & & 5 & 6 & 6 & 5 & 5 & & 5 & & \\
\hline 8 & & & 8 & 10 & 10 & 5 & 5 & & 8 & & \\
\hline . & , & $\Rightarrow$ & , & 3 & 3 & $=$ & a & 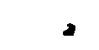 & 2 & 2 & a \\
\hline & & & & 4 & 4 & & & & & & \\
\hline & & & & 5 & 5 & & & & & & \\
\hline & & & & 10 & 10 & & & & & & \\
\hline & & & & 10 & 10 & & & & & & \\
\hline 5 & 0 & 10 & 10 & 10 & 10 & 10 & 10 & 10 & 5 & 10 & 10 \\
\hline 5 & 8 & 8 & 10 & 9 & 9 & 10 & 10 & 8 & 5 & 8 & 8 \\
\hline 5 & 5 & 5 & 10 & 8 & 8 & 10 & 10 & 5 & 5 & 5 & 5 \\
\hline 5 & 3 & 3 & 10 & 7 & 7 & 10 & 10 & 3 & 5 & 3 & 3 \\
\hline 5 & 0 & 0 & 5 & 6 & 6 & 5 & 5 & 0 & 5 & 0 & 0 \\
\hline 5 & 0 & 0 & 0 & -1 & -1 & 5 & 0 & -1 & 5 & -1 & -1 \\
\hline 5 & 1 & 1 & 0 & 0 & 0 & 5 & 0 & 0 & 5 & 0 & 0 \\
\hline 5 & 3 & 3 & 3 & 5 & 5 & 5 & 3 & 1 & 5 & 1 & 1 \\
\hline 5 & 5 & 5 & 4 & 5 & 5 & 5 & 4 & 3 & 5 & 3 & 3 \\
\hline 5 & 10 & 10 & 5 & 5 & 5 & 5 & 5 & 10 & 5 & 10 & 10 \\
\hline 0 & , & 2 & 0 & -1 & -1 & 5 & 5 & a & 0 & a & 2 \\
\hline 0 & & & 0 & -1 & -1 & 5 & 5 & & 0 & & \\
\hline 0 & & & 0 & 2 & 2 & 5 & 5 & & 0 & & \\
\hline 3 & & & 3 & 5 & 5 & 5 & 5 & & 3 & & \\
\hline 5 & & & 5 & 10 & 10 & 5 & 5 & & 5 & & \\
\hline 5 & 1 & -1 & 0 & 0 & 0 & 5 & 0 & -1 & 5 & -1 & -1 \\
\hline 5 & 5 & 5 & 0 & n & 0 & 5 & 0 & 4 & 5 & 6 & 4 \\
\hline 5 & 5 & 5 & 3 & 3 & 3 & 5 & 3 & 4 & 5 & 6 & 4 \\
\hline 5 & 5 & 5 & 5 & J & 5 & 5 & 5 & 4 & 5 & 6 & 4 \\
\hline 5 & 10 & 10 & 5 & 10 & 10 & 5 & 5 & 10 & 5 & 10 & 10 \\
\hline 5 & -1 & -1 & 0 & 0 & 0 & 5 & 0 & -1 & 5 & -1 & -1 \\
\hline 5 & -1 & -1 & 0 & 0 & 0 & 5 & 0 & -1 & 5 & -1 & -1 \\
\hline 5 & 5 & 5 & 5 & 3 & 3 & 5 & 5 & 4 & 5 & 5 & 5 \\
\hline 5 & 6 & 6 & 8 & 5 & 5 & 5 & 8 & 5 & 5 & 6 & 6 \\
\hline 5 & 10 & 10 & 10 & 10 & 10 & 5 & 10 & 10 & 5 & 10 & 10 \\
\hline
\end{tabular}


Appendix B

CORRELATION MATRIX OF CELL SUITABILITY SCORES OBTAINEC FROM CALCULATIONS OF VARIOUS SITING CRITERIA MATRICES 
Appandix $\mathbf{B}$

CORRELATION MATRIX OF CELL SUITADILITY SCOAES OBTAINED FAOM CALCULATIONS OF VAAIOUA BITINO CAITEAIA MATAICES

\begin{tabular}{|c|c|c|c|c|c|c|c|c|c|c|c|c|c|c|c|c|c|}
\hline Tectinolog/siting objective/respondon! & $\begin{array}{l}\text { Voriable } \\
\text { number }\end{array}$ & V1 & V2 & $v:$ & V4 & V5 & V6 & V7 & V8 & V9 & V10 & v11 & V12 & V13 & v14 & Vis & V16 \\
\hline $\begin{array}{l}\text { Fossil with cooling tower/composite } \\
\text { of all objectives/PPSP' }\end{array}$ & V1 & 1.0 & 0.83 & 0.70 & 0.18 & 0.93 & 0.75 & 0.68 & 0.16 & 0.67 & 0.64 & 0.21 & 0.18 & 0.25 & 0.41 & 0.36 & 0.41 \\
\hline $\begin{array}{l}\text { Fossl with cooling tomer/minimization } \\
\text { of conslfuction costs/PPSP }\end{array}$ & $\mathbf{v z}$ & & 1.0 & 0.28 & -0.07 & 0.77 & 0.95 & 0.28 & -0.04 & 0.40 & 0.50 & 0.21 & 0.18 & 0.27 & 0.38 & 0.38 & 0.39 \\
\hline $\begin{array}{l}\text { Fossil with cooling tower/minimization } \\
\text { of advers ecologic impact/PPSP }\end{array}$ & v3 & & & 1.0 & 0.12 & 0.58 & 0.17 & 0.99 & -0.17 & 0.76 & 0.13 & 0.44 & 0.41 & 0.34 & 0.48 & 0.43 & 0.78 \\
\hline $\begin{array}{l}\text { Fossil with cooling lower/minimization } \\
\text { of sociooconomic impuct/PPSP }\end{array}$ & va & & & & 1.0 & 0.44 & -0.01 & -0.12 & 0.89 & 0.62 & 0.59 & -0.32 & -0.36 & $-0.2 B$ & 0.29 & 0.34 & 0.28 \\
\hline $\begin{array}{l}\text { Nucleas with cooling lown/composite } \\
\text { of all objectives/PPSP }\end{array}$ & V5 & & & & & 1.0 & 0.77 & 0.67 & 0.44 & 0.74 & 0.78 & -0.02 & 0.07 & 0.04 & $0.2 ?$ & 0.20 & 0.29 \\
\hline $\begin{array}{l}\text { Nucloas with cooling towm/minimization } \\
\text { of construction costs. IP }\end{array}$ & V6 & & & & & & 1.0 & 0.18 & 0.02 & 0.49 & 0.66 & 0.10 & 0.07 & 0.20 & 032 & 0.30 & 0.37 \\
\hline $\begin{array}{l}\text { Nucleas witt coo!ing towor/minimization } \\
\text { of adverse ecologic impact/PPSP }\end{array}$ & V7 & & & & & & & 1.0 & -0.16 & 0.12 & 0.16 & 0.45 & 0.43 & 0.36 & 0.48 & 0.42 & 0.38 \\
\hline $\begin{array}{l}\text { Nucles with cooling tower/minimization } \\
\text { of socioaconomic impact/PPsp }\end{array}$ & V8 & & & & & & & & 1.0 & 0.63 & 0.50 & -0.20 & 0.33 & -0.22 & 0.27 & . 0.32 & 0.26 \\
\hline $\begin{array}{l}\text { Nucleas with cooling lower/composite of } \\
\text { all objoctives/First Nominal Group }\end{array}$ & vg & & & & & & & & & 1.0 & 0.92 & 0.05 & 0.12 & 0.01 & 0.01 & 0.10 & 0.01 \\
\hline $\begin{array}{l}\text { Nuctar with cooling lower/minimizalion } \\
\text { all obipctives/Second Nominal Group }\end{array}$ & vio & & & & & & & & & & 1.0 & 0.00 & 0.01 & 0.02 & 0.11 & $0.0 \mathrm{~s}$ & 0.09 \\
\hline $\begin{array}{l}\text { Mucles with cooling tower/minimization } \\
\text { of edverso ocologic impact/OANL }\end{array}$ & Vir & & & & & & & & & & & 1.0 & 0.80 & 0.84 & 0.85 & 0.94 & 0.89 \\
\hline $\begin{array}{l}\text { Nuctear with cooling pond/minimization of } \\
\text { edwerse ecologic impact/r?ANL }\end{array}$ & $v_{12}$ & & & & & & & & & & & & 1.0 & 0.83 & 0.94 & 0.95 & 0.87 \\
\hline $\begin{array}{l}\text { Nuctear once ithough/mini nizat on of } \\
\text { adverse ocologic impact//iANL }\end{array}$ & V13 & & & & & & & & & & & & & 1.0 & 0.85 & 0.82 & 0.83 \\
\hline $\begin{array}{l}\text { Fossil with cooling tower/minimization of } \\
\text { sdwerse ccologic imaxct/ORNL }\end{array}$ & V14 & & & & & & & & & & & & & & 1.0 & 0.88 & 0.96 \\
\hline $\begin{array}{l}\text { Fossil with cooling pond/minimization of } \\
\text { sotwers ecologic impact/ORNL }\end{array}$ & V15 & & & & & & & & & & & & & & & 1.0 & 0.93 \\
\hline $\begin{array}{l}\text { Fossil once through/minimization of } \\
\text { adverso ecologic impect/OANL }\end{array}$ & V16 & & & & & & & & & & & & & & & & 1.0 \\
\hline
\end{tabular}

'Ppsp - Powar Plent Siting Program. Maryland Department of Natural Resources.

?ORNL - Oak Ridep Nationst Laboratory. 